\title{
DESIGNATION OF LECTOTYPES OF SOME OSTRACODS FROM THE CHALLENGER EXPEDITION
}

\author{
By H. S. PURI and N. C. HULINGS
}

CONTENTS

\begin{tabular}{|c|c|c|c|c|c|c|c|c|c|c|}
\hline SyNOPSIS. & . & - & . & . & - & - & . & · & $\cdot$ & 254 \\
\hline INTRODUCTION . & . & . & · & . & - & . & · & $\cdot$ & . & 254 \\
\hline \multicolumn{11}{|l|}{ GENUs Phlyctenophora } \\
\hline P. zealandica Brady & . & . & - & - & · & • & · & · & & 25 \\
\hline \multicolumn{11}{|l|}{ Genus Aglaia } \\
\hline A. clavata Brady & . & . & . & . & - & • & · & . & & \\
\hline A. (?) meridionalis $\mathrm{Br}$ & rady & . & . & . & - & . & . & • & & \\
\hline A. (?) obtusata Brady & . & . & . & . & . & . & . & . & . & 57 \\
\hline A. (?) pusilla Brady & . & . & . & . & . & . & . & - & . & \\
\hline \multicolumn{11}{|l|}{ Genus Pontocypris } \\
\hline P. simplex Brady & . & . & . & . & . & . & . & . & . & $25^{\varepsilon}$ \\
\hline$P$. (?) subreniformis $\mathrm{B}$ & Brady & . & . & . & . & . & . & • & · & \\
\hline \multicolumn{11}{|c|}{ Genus Argilloecia } \\
\hline A. eburnea Brady & . & . & . & . & . & . & . & . & . & \\
\hline (?) A. badia Brady & . & . & . & . & . & . & . & . & . & \\
\hline \multicolumn{11}{|l|}{ Genus Macrocypris } \\
\hline M. canariensis Brady & & . & . & · & - & - & - & · & • & \\
\hline M. setigera Brady & . & . & . & . & . & - & . & • & r & \\
\hline M. similis Brady & . & . & . & . & . & . & . & • & 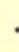 & \\
\hline M. tenuicauda Brady & . & . & . & . & . & . & . & . & . & \\
\hline M. tumida Brady & . & . & . & . & . & . & . & . & . & 20 \\
\hline \multicolumn{11}{|l|}{ Genus Bythocypris } \\
\hline B. elongata Brady & . & . & . & . & - & - & - & . & . & \\
\hline B. reniformis Brady & . & . & - & . & . & - & - & . & · & 26 \\
\hline \multicolumn{11}{|l|}{ Genus Bairdia } \\
\hline B. abyssicola Brady & . & . & . & . & . & • & . & • & • & \\
\hline B. attenuata Brady & . & . & . & . & . & . & . & • & . & \\
\hline B. exaltata Brady & . & • & . & . & . & - & · & • & . & \\
\hline B. expansa Brady & . & - & - & . & . & . & . & · & $\cdot$ & \\
\hline B. fortificata Brady & . & . & - & - & - & - & . & . & $\cdot$ & \\
\hline B. globulus Brady & . & . & - & . & - & - & . & • & - & \\
\hline B. hirsuta Brady & . & . & . & . & . & . & . & • & . & 2 \\
\hline B. minima Brady & . & . & . & . & . & . & . & . & . & 26 \\
\hline B. simplex Brady & . & . & . & . & . & . & . & . & . & 26 \\
\hline B. villosa Brady & . & . & . & . & . & . & . & . & . & 26 \\
\hline B. woodwardiana Brac & & . & . & . & - & . & · & · & . & 26 \\
\hline \multicolumn{11}{|l|}{ Genus $C y$ there } \\
\hline C. acanthoderma Brad & & . & - & . & . & . & . & . & . & 26 \\
\hline C. acupunctata Brady & & . & . & . & . & . & . & • & . & \\
\hline C. arata Brady . & . & . & . & . & . & . & . & . & . & $26 \varepsilon$ \\
\hline C. bicarinata Brady & . & . & . & . & . & . & . & . & & \\
\hline
\end{tabular}


C. circumdentata Brady

C. clavigera Brady

C. craticula Brady

C. cristatella Brady

C. cumulus Brady

C. curvicostata Brady .

C. cytheropteroides Brady

C. dasyderma Brady

C. dictyon Brady

C. dorsoserrata Brady .

C. ericea Brady

C. exfoveolata Neviani .

C. exilis Brady

C. falklandi Brady

C. flabellicostata Brady

C. floscardui Brady

C. fulvotincta Brady

C. hardingi nom. nov. .

C. impluta Brady

C. inconspicua Brady .

C. irpex Brady .

C. irrorata Brady

C. kerguelenensis Brady

C. (?) laganella Brady .

C. lauta Brady .

C. lepralioides Brady .

C. lubbockiana Brady .

C. mackenziei nom. nov.

C. moseleyi Brady

C. murrayana Brady

C. obtusalata Brady

C. packardi Brady

C. papuensis Brady

C. parallelogramma Brady

C. patagoniensis Brady

C. quadriaculeata Brady

C. radula Brady.

C. vastromarginata Brady

C. sabulosa Brady

C. scalaris Brady

C. scintillulata Brady

C. securifer Brady

C. (?) serratula Brady .

C. scabrocuneata Brady

C. squalidentata Brady

C. stolonifera Brady

C. subrufa Brady

C. suhmi Brady .

C. sulcatoperforata Brady

C. torresi Brady .

C. tricristata Brady

C. tetrica Brady .

C. velivola Brady 


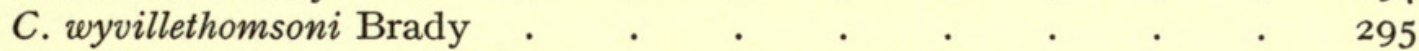

Genus Krithe

K. hyalina Brady

K. producta Brady

295

295

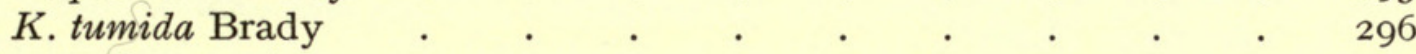

Genus Loxoconcha

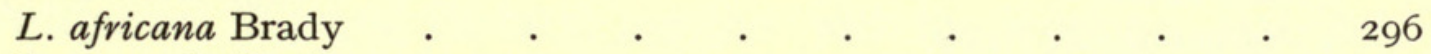

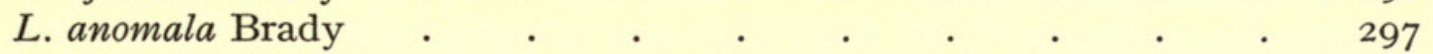

L. australis Brady $\quad . \quad$. $\quad$. $\quad$. $\quad$. $\quad$. $\quad$. $\quad . \quad$. 297

L. honoluliensis Brady $\quad . \quad$. $\quad . \quad$. $\quad$. $\quad$. $\quad . \quad$. 297

L. pumicosa Brady . $\quad . \quad$. $\quad . \quad$. $\quad . \quad$. $\quad . \quad$. 298

L. subrhomboidea Brady . $\quad$. $\quad$. $\quad$. $\quad$. $\quad . \quad$. $\quad$.

Genus Xestoleberis

$X$. africana Brady

$X$. expansa Brady

$X$. foveolata Brady

$X$. granulosa Brady

$X$. nana Brady .

$X$. setigera Brady

$X$. tumefacta Brady

$X$. variegata Brady

Genus Cytherura

C. clavata Brady

C. clausi Brady .

C. costellata Brady

C. cribrosa Brady

C. cryptifera Brady

C. curvistriata Brady

C. lilljeborgi Brady

C. mucronata Brady

Genus Cytheropteron

C. abyssorum Brady

C. (?) angustatum Brady

C. assimile Brady

C. fenestratum Brady .

C. mucronalatum Brady

C. patagoniense Brady

C. scaphoides Brady

C. wellingtoniense Brady

Genus Bythocythere

$B$. arenacea Brady

$B$. (?) exigua Brady

$B$. pumilio Brady

$B$. velifera Brady

299

299

300

300

301

301

302

302

303

303

304

304

304

304

304

305

305

305

306

306

307

307

307

308

308

309

309

309

Genus Pseudocythere

P. fuegiensis Brady

Genus Cytherideis

C. laevata Brady

Genus Xiphichilus

$X$. (?) arcuatus Brady .

$X$. complanatus Brady 


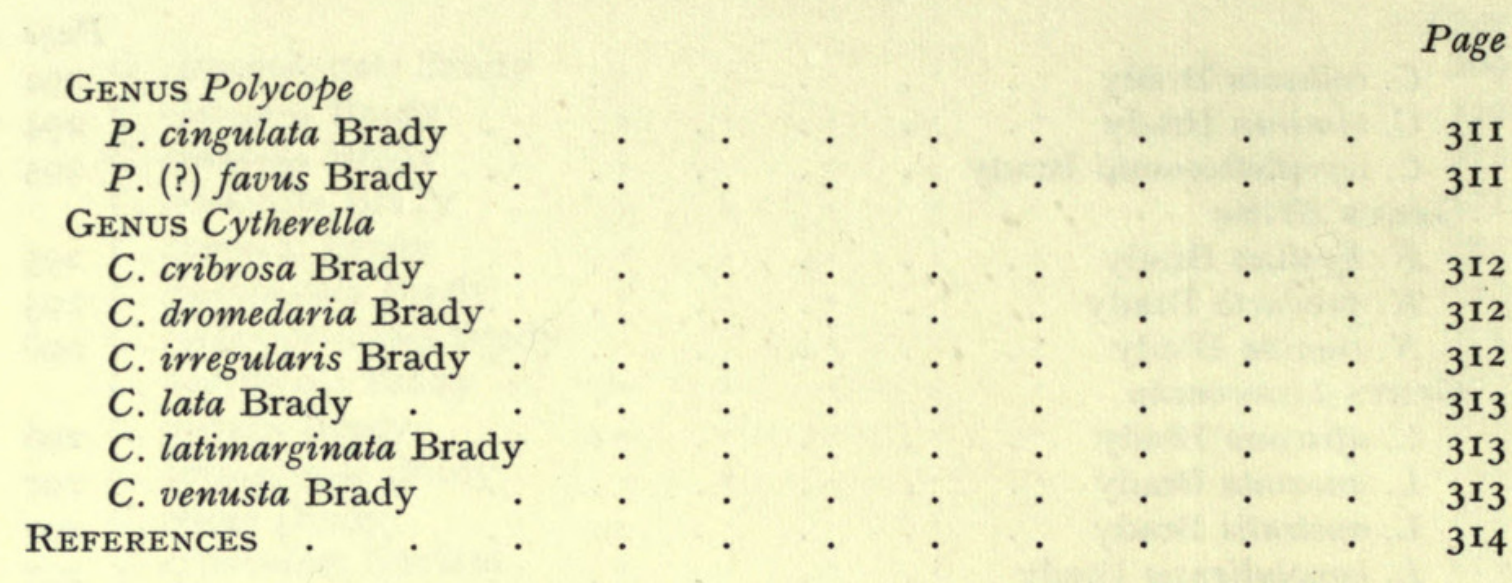

\section{SYNOPSIS}

Syntype material of recent ostracods described by G. S. Brady from the Challenger Expedition and deposited in the British Museum (Natural History) and the Hancock Museum, Newcastle upon Tyne, is redescribed. Lectotypes are selected where appropriate and topotypic material identified. Neotypes are established for Xestoleberis tumefacta Brady, Bythocythere velifera Brady and Cytherella latimarginata Brady. New names are proposed for Cythere ovalis Brady and C. pyriformis Brady.

\section{INTRODUCTION}

IN order to stabilize ostracod nomenclature, one of us (H. S. P.) initiated a restudy and redescription of the classic European collections of G. W. Müller, G. S. Brady and G. O. Sars. The present contribution is a study of some syntype material deposited in the British Museum (Natural History) and the Hancock Museum, Newcastle upon Tyne. A complete list of species collected during the voyage of the H.M.S. Challenger and catalogued at the British Museum (Natural History) was prepared by Dr R. H. Bate (see Bate, I963).

We would like to express our gratitude to Dr J. P. Harding, formerly Keeper of Zoology, Mrs Patricia Barker and Dr K. G. McKenzie for their encouragement; and to Dr R. H. Bate, Dr K. G. McKenzie, Mr G. Bennell and Miss Ann Gurney for editorial assistance. The stereoscan photographs for Plates 26 and 27 were taken by Miss Gurney. Through the courtesy of Mr A. M. Tynan, Curator, The Hancock Museum, Newcastle upon Tyne, we were able to examine Brady's syntype material deposited in the Hancock Museum. Dr H. V. Howe kindly made available to us his exhaustive index on ostracods. We wish to thank Dr R. H. Benson for critically reading the manuscript and offering helpful comments. The study of Brady's Challenger ostracods was supported by NSF Grant GB 6706.

The descriptive notes which follow the designation of each lectotype are meant to supplement the descriptions given by Brady. The species are arranged in the text and the plates in the same order as they appear in the Challenger monograph and we have used Brady's nomenclature except for two homonyms which are renamed. Short synonomies are given with each species.

Originally it was planned to prepare scanning electron micrographs of the British Museum (Natural History) types, but it was decided not to use this method for fear of damaging the specimens. Consequently, photographs were taken by $\mathrm{Dr}$ 
R. H. Benson at the Smithsonian Institution in Washington, and these are published as Pls I-25. Through the kindness of Dr R. H. Bate, we were able to obtain a small portion of the original Challenger sediment samples. Specimens obtained from these samples were used to supplement Brady's syntype material.

Scanning electron photornicrographs of these specimens were prepared by Mr Ron Parker, in Tallahassee, and at the Department of Geology, University of Delaware, Newark, Delaware, through the courtesy of Dr F. W. Swain. These are lodged at the British Museum (Natural History) together with the topotypic material. Two plates of scanning photomicrographs are included in this paper. Lectotypes of seven species described by Brady (I880) have already been established. Type specimens of Cythere scabrocuneata Brady were established by Harding \& SylvesterBradley (I953). Benson (I97I) established an early instar as lectotype for Cythere squalidentata Brady (considered by Benson as a nomen dubium), and he subsequently (Benson, I972) established lectotypes for Cythere arata Brady, Cythere dictyon Brady, Cythere rastromarginata Brady, Cythere radula Brady and Cythere vimea Brady. Illustrations of the above lectotypes established by Benson appear in this paper.

Richard H. Benson prepared the following text on photographic techniques. 'The photographic equipment used was the Leitz Aristophot Microscope with Ultrapac lenses and $35 \mathrm{~mm}$ camera. The specimens were placed either dry (for incident illumination) or in immersion (for transmitted and black light) on glass so that extraneous light would pass through rather than be reflected by the background. A single light source was used for incident illumination in conjunction with a paper diffusing ring held close to the specimen. The background of incident light photographs could be varied from light to dark with the aid of an off-centre substage light and variable rheostat. Conventional techniques were used for the transmitted light photographs, but the lenses had a longer working distance and greater depth of field than those usually employed in photomicrography. Inadequate depth of field still is a limitation to the use of conventional photomicrography for illustration of ostracods. One will notice this in many of the figures in the present work. Every photograph was a compromise of some kind, especially with the large or thick specimens.

'With the use of transmitted light and immersion of the specimen in water or glycerine many features that Brady did not illustrate could be seen. Many musclescar patterns, hinges, surface ornament, and marginal area features are now shown for comparison with specimens collected elsewhere. It is regretted that all of these characters could not be illustrated by photography for all forms. Attempts were made to obtain photographs of these features wherever they could be seen.'

Illustration was confined to new species found and described by Brady from the Challenger samples. There are many others which had been previously described and which he identified. Four of these are illustrated on Pl. 25. These were thought to have special interest and were included while the opportunity was at hand. These include Cythere melobesioides Brady, I869, Cythere cymba Brady, I869, Cythere polytrema Brady, I878, and Cythere euplectella Brady, I869.

The following species have not been illustrated as specimens could not be found either in the collection or in the topotype material: Cythere fortificata, Bythocypris 
compressa and Cytherura obliqua. Type specimens of Cytherella latimarginata were lost and a neotype is selected.

There are some discrepancies between Brady's description of stations and the narrative of the Challenger cruise (Tizard et al., I885). Under each type locality, data provided by Brady on the slides are given and the additional data which are documented in the narrative are given in parentheses after each station.

\section{Genus PHLYCTENOPHORA \\ Phlyctenophora zealandica Brady}

(Pl. I, figs $I 7, I 8$ )

Phlyctenophora zealandica Brady, 1880 : 33, pl. 3, figs ra-m.

Figured specimen. Articulated carapace (split), BM 8r.5.7. Length $0.88 \mathrm{~mm}$; height $0.38 \mathrm{~mm}$. Type locality: Humboldt Bay, Papua, 37 fathoms.

DESCRIPTION. Shape and ornamentation essentially as given by Brady (I880). Inner lamella: anterior and posterior vestibula present, latter larger ; ventral shelf present. Marginal pore canals anteriorly branching, several main canals each giving off numerous smaller canals ; posteriorly, simple straight canals. Hinge difficult to discern. Right valve apparently with anterior and posterior sockets and median bar.

Remarks. Pl. I, figs I7, I8 represent the specimen labelled by Brady as 'Phlyctenophora zealandica' in the British Museum collection and may not represent Brady's concept of this species. Brady also figured the soft parts of this species. The selection of a lectotype is deferred until living specimens are found in adequate quantity and described. Topotypic material: disarticulated left and right valves, BM I974.246.

\section{Genus AGLAIA}

Aglaia clavata Brady

(P1. 2, figs I6, I7)

Aglaia clavata Brady, 1880 : 34, pl. 6, figs 4a-d.

Lectotype. Disarticulated left and right valves, BM 8I.5.I (separated after photography). Length of articulated carapace $0.56 \mathrm{~mm}$; greatest height $0.23 \mathrm{~mm}$. Type locality: Wellington Harbour, New Zealand (trawl-net).

DESCRIPTION. Shape and ornamentation as given by Brady (I880), see Pl. 2, figs 16 and I7. Inner lamella: marginal zone narrow in anterior and posterior ends ; wide along middle two-thirds of ventral margin. Anterior and posterior vestibula large. Line of concrescence irregular. Marginal pore canals: anterior canals numerous and simple. No pore canals seen on ventral or posterior end. Hinge adont. Central muscle scars: five scars divided into an anterior row of three and two posterior. 


\section{Aglaia (?) meridionalis Brady}

(P1. 20, figs 4-6)

Aglaia (?) meridionalis Brady, $1880: 34,35$, pl. 30, figs $7 \mathrm{a}-\mathrm{d}$.

LEстотуPE. Left valve with outer margin fractured, BM I96r.I2.4.63. Length $0.65 \mathrm{~mm}$; height $0.28 \mathrm{~mm}$. Type locality: Stat. 316, Stanley Harbour, Falklands, 6 fathoms. $\left(51^{\circ} 32^{\prime} \mathrm{o}^{\prime \prime} \mathrm{N}, 58^{\circ} 06^{\prime} \mathrm{o}^{\prime \prime} \mathrm{W}\right.$, dredged, 4 fathoms, mud, surface temp. $5 \mathrm{I} \cdot 2^{\circ} \mathrm{F}$, February $3, \mathrm{I} 876$.)

DESCRIPTION. Shape and ornamentation as given by Brady (I880). Inner lamella not distinguishable on lectotype. Central muscle scars: see Pl. 20, fig. 6.

\section{Aglaia (?) obtusata Brady}

(Pl. 20, figs 7,8 )

Aglaia (?) obtusata Brady, I880: 35, pl. 30, figs 8a-d.

Lectotype. Disarticulated right and left valves, BM 80.38.4 (separated after photography). Right valve: length $0.55 \mathrm{~mm}$; height $0.27 \mathrm{~mm}$; left valve: length $0.52 \mathrm{~mm}$; height $0.24 \mathrm{~mm}$. Type locality: Stat. I49, Balfour Bay, Kerguelen Island. (49 ${ }^{\circ} 8^{\prime} \mathrm{O}^{\prime \prime} \mathrm{S}, 70^{\circ} \mathrm{I} 2^{\prime} \mathrm{O}^{\prime \prime} \mathrm{E}$, dredged, 20-50 fathoms, dark mud, January 9 , I874.)

Description. Shape as given by Brady (I880) for right valve. Left valve smaller, anterior and posterior ends less broadly rounded than right valve, ventral surface sinuate near middle. Ornamentation as given by Brady (I880). Inner lamella: line of concrescence irregular; anterior and posterior vestibula, the former large and the latter reduced, marginal area narrow anteriorly and posteriorly, wide ventrally. Marginal pore canals numerous and simple at anterior end, few and simple, some false at posterior end. Hinge adont. Central muscle scars: anterior row of three and posterior row of two making a total of five scars. Overlap: right valve overlaps the left valve.

\section{Aglaia (?) pusilla Brady}

(Pl. 20, figs I-3)

Aglaia (?) pusilla Brady, I88o : 34, pl. 3o, figs 6a-d.

Lectotype. Disarticulated right and left valves, BM 81.5.2. Right valve: length $0.5 \mathrm{I} \mathrm{mm}$; height $0.22 \mathrm{~mm}$; left valve : length $0.50 \mathrm{~mm}$; height $0.20 \mathrm{~mm}$. Type locality: Stat. I62, dredged off East Moncœur Island, Bass Strait, 38-40 fathoms. (39 ${ }^{\circ} \mathrm{I0}^{\prime} 3 \mathrm{0}^{\prime \prime} \mathrm{S}, \mathrm{I} 46^{\circ} 37^{\prime} \mathrm{o}^{\prime \prime} \mathrm{W}$, surface temp. $63 \cdot 2^{\circ} \mathrm{F}$, April 2, I874.)

DESCRIPTION. Shape and ornamentation as given by Brady (I880). Inner lamella: line of concrescence irregular, anterior and posterior vestibula with anterior larger, marginal area narrow anteriorly and posteriorly, wide ventrally. See Pl. 20, figs I and 3. Marginal pore canals numerous and simple anteriorly. Hinge adont. 
Central muscle scars: five scars, vertical row of three anteriorly and two posteriorly. See Pl. 20, fig. 2. Overlap: right valve overlaps the left.

Remarks. Brady (I880, p. 34) found this species only at Stat. I62; sediment sample M-I95, which represents this station, yielded a single articulated carapace. Topotypic material: a complete carapace, BM r974.250.

\title{
Genus PONTOCYPRIS
}

\section{Pontocypris simplex Brady}

$$
\text { (Pl. I, figs 6-8) }
$$

Pontocypris simplex Brady, 1880 : 37, pl. I, figs 5a-d.

LEстотуре. Disarticulated right and left valves of a complete specimen, BM 8I.5.4 (separated during photography). Right valve: length $0.62 \mathrm{~mm}$; height $0.3 \mathrm{I} \mathrm{mm}$; left valve: length $0.62 \mathrm{~mm}$; height $0.31 \mathrm{~mm}$. Type locality: Stat. 344. Off Ascension Island, $7 \mathrm{I}$ fathoms.

DESCRIPTION. Shape and ornamentation as given by Brady (1880). Inner lamella: large anterior and posterior vestibula. Duplicature widest ventrally. Inner margin coincides with the line of concrescence only ventrally. Ventral margin expanded to form a small shelf in both valves. Marginal pore canals short, simple, straight, most numerous anteriorly. A few false canals ventrally. Hinge adont. Groove in right valve. Normal pores numerous, small, open. Central muscle scars: adductor consists of five scars.

\section{Pontocypris (?) subreniformis Brady}

\author{
(Pl. 3, fig. I6)
}

Pontocypris (?) subreniformis Brady, 1880:38, 39; pl. 7, figs 5a-d, not Pontocypris (?) subtriangularis Brady, 1880: pl. 15, figs 6a-d (nom. nud.).

LECTотуPE. Disarticulated right and left valves, right valve cracked ventrally, BM 8I.5.5 (separated after photography). Right valve : length $0.65 \mathrm{~mm}$; height $0.34 \mathrm{~mm}$; left valve: length $0.62 \mathrm{~mm}$; height $0.34 \mathrm{~mm}$. Type locality: Port Jackson, Australia, 2-Io fathoms, April 20, I874.

Description. Shape of left valve as given by Brady (I880), except that on the type, the anterior end is rounded rather than depressed, the posterior is more acutely rounded. Right valve the same but with the dorsal surface more evenly arched. See P1. 3, fig. I6. Ornamentation as given by Brady (I880). Inner lamella: anterior and posterior vestibula present with the former the largest, line of concrescence and inner margin coincide ventrally where the lamella is the widest. Ventral margin expanded to form a shelf. Marginal pore canals short, straight and simple. Hinge adont. Right valve with a groove for the dorsal border of the left valve. Normal pores small and open. 
Remarks. Brady (I88o, pp. 38, 39) described this species from two stations (Stat. I40, Simon's Bay, South Africa, I5-20 fathoms, and Port Jackson). Port Jackson is the type locality of the lectotype. The lectotype resembles Brady's illustration on pl. 7 (figs $5 \mathrm{a}-\mathrm{d}$ ), the topotypes are much longer and may represent forms figured by Brady on pl. 7 (figs 5a-d) as 'subtriangularis'. Both of these forms belong to Propontocypris as shown by muscle scars and other internal features. Topotypic material: BM I974.249.

\title{
Genus ARGILLOECIA
}

\section{Argilloecia eburnea Brady}

\author{
(Pl. 2, figs 5,6 )
}

Avgilloecia eburnea Brady, I880:40, pl. 4, figs I-15.

Lectotype. Left valve, BM 80.38.9. Length $0.8 \mathrm{I} \mathrm{mm;} \mathrm{height} 0.34 \mathrm{~mm}$. Type locality: Stat. I49, Balfour Bay, Kerguelen Island, 20-50 fathoms, January I874.

DESCRIPTION. Shape and ornamentation as given by Brady (I880). Inner lamella: anterior and posterior vestibula large, marginal area narrow. Marginal pore canals simple. Hinge adont. Central muscle scars: five scars, anterior vertical row of three and posterior row of two. See Pl. 2, fig. 6.

REMARKs. Brady (I88o, p. 40) reported this species as occurring 'plentifully' from two dredgings from Kerguelen Island-Balfour Bay $(20-50$ fathoms) and off Christmas Harbour (I20 fathoms). The lectotype is from Stat. I49 (Balfour Bay) and the topotypic specimen was obtained from sediment sample M-I83 which represents the Christmas Harbour dredging. Topotypic material: a complete carapace, BM I974.25I.

\section{Argilloecia badia Brady}

$$
\text { (P1. 27, figs I, 2) }
$$

Argilloecia badia Brady, 1880: 40, pl. 6, figs 3a-d.

Figured SPECimen. Complete carapace, BM I974.252. Length $0.84 \mathrm{~mm}$; height $0.40 \mathrm{~mm}$. Type locality: Port Jackson, Australia, 2-Io fathoms, April 20, I874.

Remarks. Brady (I880) reported this species from Port Jackson. Sediment sample M-I98 yielded several specimens and a right valve is figured on Pl. 27. The type specimens of this species were evidently lost. There are no specimens in British Museum (Natural History) and none are at the Hancock Museum ( fide letter by Mrs O. Marshall, secretary to Mr A. M. Tynan, Curator, Hancock Museum, dated July 24 , I967, to H. S. Puri). The form questionably identified and figured here is twice as large as the one figured by Brady, I880 (length $0.4 \mathrm{~mm}$ ). More material is needed in order to select a neotype. 


\section{Genus MACROCYPRIS \\ Macrocypris canariensis Brady}

(P1. I, figs I5, I6)

Macrocypris canariensis Brady, 1880 : 42, pl. 2, figs 3a-d.

LECTOTYPE. Disarticulated right and left valves. Both valves eroded, BM 8r.5.6 (separated after photography). Right valve: length I.94 mm; height $0.68 \mathrm{~mm}$; left valve: length $\mathrm{I} .98 \mathrm{~mm}$; height $0.60 \mathrm{~mm}$. Type locality: off Canary Island, 620 fathoms. $\left(28^{\circ}{ }^{\circ} 3^{\prime} 15^{\prime \prime} \mathrm{N}, 17^{\circ} 27^{\prime} \mathrm{o}^{\prime \prime} \mathrm{W}\right.$, dredged, surface temp. $64 \cdot 5^{\circ} \mathrm{F}$. $)$

DEscription. Shape and ornamentation essentially as given by Brady (I880). Inner lamella: wide anteriorly and posteriorly with vestibulum present at both ends. Ventral shelf present. Marginal pore canals straight, simple. Hinge merodontentomodont. Right valve with anterior and posterior terminal sockets and median bar. Left valve with anterior and posterior terminal teeth and median groove. Teeth, sockets and terminal portions of median bar smooth. Normal pores small, open, mostly on ventral half of valves.

\section{Macrocypris setigera Brady}

(Pl. I, figs $\mathrm{I}-5$ )

Macrocypris setigera Brady, I880 : 43, pl. I, figs Ia-d.

LECTотуре. Left and right valves of a disarticulated specimen, BM 80.38.2 (separated after photography). Right valve: length I.20 mm; height $0.50 \mathrm{~mm}$; left valve: length I.2I mm; height $0.54 \mathrm{~mm}$. Type locality: Port Jackson, Australia, 2-Io fathoms, April 20, I874.

DESCRIPTION. Shape and ornamentation as given by Brady (I880) except for absence of setae. Inner lamella: wide anteriorly and posteriorly, narrow ventrally. Line of concrescence and inner margin coincide for a very short distance ventrally. Wide vestibula ventrally. Marginal pore canals numerous and branching, some false. Longest ventrally, short anteriorly and posteriorly. See Pl. I, figs 4 and 5 . Hinge adont. Left valve with a shallow groove. Normal pores numerous, scattered, small open. Central muscle scars: see Pl. I, fig. 3, the complex consists of seven adductor scars.

Remarks. Topotypic material: a complete carapace, BM I974.245.

\section{Macrocypris similis Brady}

(P1. I, figs I3, I4)

Macrocypris similis Brady, I880:42, pl. 2, figs $2 a-d$.

Lectotype. Right valve, BM 80.38.I4. Length $\mathrm{I} \cdot 72 \mathrm{~mm}$; height $0.62 \mathrm{~mm}$. Type locality: Stat. I20, off Pernambuco, 675 fathoms. $\left(8^{\circ} 37^{\prime} \mathrm{o}^{\prime \prime} \mathrm{S}, 34^{\circ} 28^{\prime} \mathrm{o}^{\prime \prime} \mathrm{W}\right.$, trawled, red mud, surface temp. $78^{\circ} \mathrm{F}$, September 9, I873.) 
Description. Shape: Brady's (I880) description appears to be based on a left valve. Present type has an almost straight ventral margin, dorsal gently arched and anterior end evenly rounded. Ornamentation as given by Brady (I880). Inner lamella: line of concrescence very narrow and coincides with inner margin only ventrally; anterior and posterior vestibula present, ventral shelf narrow. See Pl. I, fig. I3. Marginal pore canals numerous, short, straight, simple. Hinge merodont-entomodont. Right valve with anterior and posterior crenulated sockets and smooth median bar. Normal pores few, small, open. Central muscle scars: see Pl. I, fig. I4. Dorsal cluster of three and ventral cluster of seven.

Remarks. Topotypic material: a left valve, BM I974.243, and a complete carapace, BM I974.244, were recovered from sediment sample M-I40 (Stat. I20).

\section{Macrocypris tenuicauda Brady}

(Pl. I, figs II, I2)

Macrocypris tenuicauda Brady, $1880: 4 \mathrm{I}, 42$, pl. 2, figs Ia-f ; pl. 3, figs 2a-b.

Leстотуре. Left valve, eroded and encrusted, BM 80.38.I6. Length I·70 mm ; height $0.60 \mathrm{~mm}$. Type locality: Stat. 24, off Culebra Island, West Indies, 390 fathoms. $\quad\left(18^{\circ} 38^{\prime} 30^{\prime \prime} \mathrm{N}, 65^{\circ} 05^{\prime} 30^{\prime \prime} \mathrm{W}\right.$, pteropod ooze, surface temp. $76^{\circ} \mathrm{F}$, March 25 , I873.)

Description. Shape: the present type differs from Brady's (I880) description in the following ways; the anterior end of type is broader and more truncated; the mid-portion of the dorsal surface is gently arched, sinuated anteriorly and gently sloping posteriorly; ventral surface sinuated near anterior. Ornamentation as described by Brady (I880). Inner lamella: anterior and posterior vestibula present. Marginal pore canals : anteriorly, five major canals each giving off numerous branches. Remainder of canals single and straight. Hinge merodont-entomodont.

Remarks. Topotypic material: several specimens (BM I974.242) of this species were recovered from sediment sample M-44 (Stat. 24).

\section{Macrocypris tumida Brady}

$$
\text { (Pl. 2, figs I3-I 5) }
$$

Macrocypris tumida Brady, $1880: 43$, pl. 6, figs 2a-d.

Leстотуре. Disarticulated right and left valves, BM 80.38.I7. Right valve: length $0.7 \mathrm{I} \mathrm{mm}$; height $0.3 \mathrm{I} \mathrm{mm}$; left valve : length $0.7 \mathrm{I} \mathrm{mm}$; height $0.28 \mathrm{~mm}$. Type locality: Stat. I49, Royal Sound, Kerguelen Island, 28 fathoms. (49 ${ }^{\circ} 8^{\prime} \mathrm{o}^{\prime \prime} \mathrm{S}$, $70^{\circ} \mathrm{I} 2^{\prime} \mathrm{O}^{\prime \prime} \mathrm{E}, 20$ fathoms, dredged, volcanic mud, January 9, I874.)

Description. Shape as described by Brady (I880) except that height is less than one-half length and ventral region is sinuate. Ornamentation as described by Brady (I880). Inner lamella: line of concrescence irregular throughout, ventrally coincides with the inner margin, large anterior and posterior vestibula present. Marginal 
pore canals numerous, straight and simple anteriorly, less numerous ventrally and posteriorly. Hinge adont. Central muscle scars: adductor scars consist of an anterior vertical row of three and a posterior row of two scars.

\section{Genus BYTHOCYPRIS}

\section{Bythocypris elongata Brady}

$$
\text { (Pl. 2, figs II, I2) }
$$

Bythocypris elongata Brady, $1880: 47$, pl. 6 , figs Ia-c.

Lectotype. Right valve, BM 8r.5.8. Length $\mathrm{I} \cdot 36 \mathrm{~mm}$; height $0.59 \mathrm{~mm}$. Type locality: Stat. 335, north of Tristan d'Acunha, I425 fathoms.

DESCRIPTION. Shape and ornamentation as given by Brady (I880). Inner lamella: line of concrescence regular, following outer margin. Marginal area narrow. Hinge adont. Normal pores open and scattered. Central muscle scars: four scars, three elongate and aligned in a vertical row anteriorly. Posterior scar rounded.

\section{Bythocypris reniformis Brady}

(Pl. 2, figs 7-IO; Fig. I)

Bythocypris veniformis Brady, $1880: 46$, pl. 5 , figs Ia-1.

Lectotype. Right valve, BM 80.38.I9. Length $\mathrm{I} \cdot 09 \mathrm{~mm}$; height $0.52 \mathrm{~mm}$. Type locality: Stat. 24, north of St Thomas, West Indies, 390 fathoms. $\left(18^{\circ} 38^{\prime} 30^{\prime \prime} \mathrm{N}\right.$, $65^{\circ}{ }^{\circ}{ }^{\prime} 30^{\prime \prime} \mathrm{W}$, dredged, pteropod ooze, surface temp. $76^{\circ} \mathrm{F}$, March 25 , 1873.)

DESCRIPTION. Shape and ornamentation as given by Brady (I880). Hinge adont. Normal pores open and scattered. Central muscle scars: adductor scars arranged in

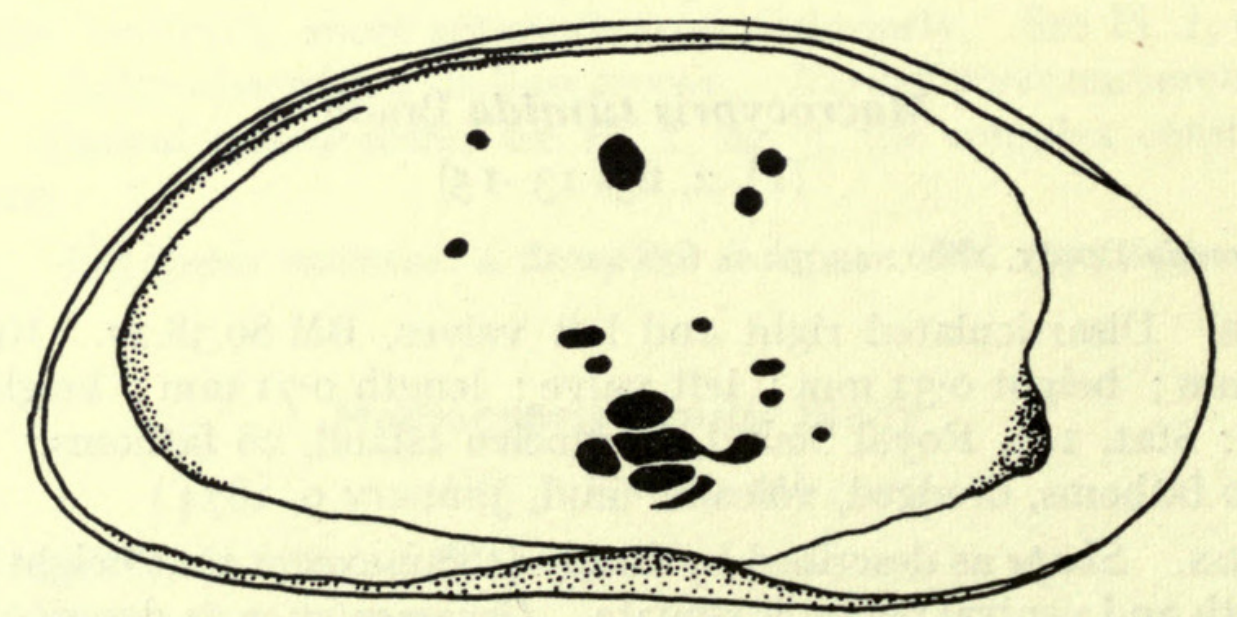

FIG. I. Bythocypris reniformis Brady: interior view of left valve of topotype, BM $1974.255(\times 85)$. 
a vertical row of three horizontal (always split) and a posteroventral scar. Antennal, frontal, mandibular and dorsal are also present (see Fig. I).

Remarks. Brady (I880, p. 46) reported this species from Stat. 24 (off Cubebra Island, West Indies, mud), Stats. I20 and I22 (off Prince Edward's Island and off Moncœur Island, Bass Strait). Topotypes were separated from sediment sample M-I69 (Prince Edward's Island, 50-I50 fathoms) where this species is common. It is also common in Stat. I22 (M-I42). Topotypic material: a complete carapace, BM I974.254, and a left valve, BM I974.255.

\section{Genus BAIRDIA}

\section{Bairdia abyssicola Brady}

(Pl. 3, fig. I5)

Bairdia abyssicola Brady, $1880: 52,53$, pl. 7, figs 4a-c.

Lectotype. Right valve, Hancock Museum. Length $\mathrm{I} \cdot 60 \mathrm{~mm}$; height $0.93 \mathrm{~mm}$. Type locality: Stat. 246, North Pacific, 2050 fathoms. (36 ${ }^{\circ} \mathrm{ro}^{\prime} \mathrm{o}^{\prime \prime} \mathrm{N}$, ${ }^{1} 78^{\circ} \mathrm{o}^{\prime} \mathrm{o}^{\prime \prime} \mathrm{E}$, trawled, grey ooze, bottom temp. $35^{\circ} \mathrm{I}^{\circ} \mathrm{F}$, surface temp. $73^{\circ} 0^{\circ} \mathrm{F}$, July 2 , I875.)

Description. Shape as given by Brady (I880). Ornamentation smooth. Inner lamella: anterior vestibule larger than posterior one. Hinge with weak terminal teeth. Central muscle scars: three elongate scars arranged vertically. Dorsal scar the shortest, the ventral scar the largest, and with a constriction two-thirds toward the posterior. The dorsal scar also has a constriction near the middle.

\section{Bairdia attenuata Brady}

$$
\text { (Pl. 5, figs 4-6) }
$$

Bairdia attenuata Brady, I880 : 59, pl. II, figs 3a-e.

Lectotype. Eroded right valve, BM 80.38.27. Length I.30 $\mathrm{mm}$; height $0.80 \mathrm{~mm}$. Type locality: Stat. I85, Torres Straits, I55 fathoms. ( $\mathrm{II}^{\circ} 35^{\prime} 25^{\prime \prime} \mathrm{S}$, I $44^{\circ}{ }^{\circ} 2^{\prime} \mathrm{o}^{\prime \prime} \mathrm{E}$, dredged, I35 fathoms, coral sand, surface temp. $77^{\circ} \mathrm{F}$, August 3I, I874.)

Description. Shape as given by Brady (I880), except that the posterior extremity is blunt rather than pointed and the dorsal surface is flat rather than arched. Ornamentation obscure because of worn surface. Inner lamella widest anteriorly. Anterior and posterior vestibula present. Hinge: posterior terminal tooth in right valve. Central muscle scars: adductor made up of a subcentral group of eight scars. The anteriormost 'scar' of the ventral row, see Pl. 5, fig. 6 , is not a scar but a hole in the shell.

Remarks. Brady (I880, p. 59) reported this form from the Torres Straits (Stat. I85) and reefs at Honolulu. Topotype specimens have been recovered from sediment sample M-237 (Stat. I85). Topotypic material: a right valve, BM I974.256, and a left valve, BM I974.257. 


\section{Bairdia exaltata Brady}

(P1. 4, figs I2-I5)

Bairdia exaltata Brady, 1880 : 51, pl. 9, figs 2a-d.

Lectotype. Right and left valves, BM 8I.5.ro. Right valve : length I.24 mm ; height $0.74 \mathrm{~mm}$; left valve : length I. $28 \mathrm{~mm}$; height $0.90 \mathrm{~mm}$. Type locality: Stat. 218 , Bismarck Sea northeast of New Guinea, ro7o fathoms. $\left(2^{\circ} 23^{\prime} \mathrm{o}^{\prime \prime} \mathrm{S}, \mathrm{I} 44^{\circ} \mathrm{O}^{\prime} \mathrm{o}^{\prime \prime} \mathrm{E}\right.$, trawled, blue mud, bottom temp. $36 \cdot 4^{\circ} \mathrm{F}$, surface temp. $84^{\circ} \mathrm{F}$, March I, I875.)

Description. Shape and ornamentation as given by Brady (I880). See Pl. 4, figs I2, I3 for details of right valve. Inner lamella: marginal area wide; vestibule varies in width; widest anteroventrally, narrowing mid-ventrally, increasing in width in posterior half of ventral region, narrowing again and finally disappearing about mid-posterior. See P1. 4, figs I2, I3 and I5. Marginal pore canals simple, straight and continuous, number about the same from anterior to posterior. Hinge: right valve with weak terminal teeth. Central muscle scars, see Pl. 4, fig. I4. Also note accessory scars.

\section{Bairdia expansa Brady}

(Pl. 5, figs $\mathrm{I}-3$ )

Bairdia expansa Brady, $1880: 58$, 59, pl. II, figs 2a-e.

Lectotype. Disarticulated right and left valves of a complete carapace, BM 8I.5.II. Right valve : length $0.7 \mathrm{I} \mathrm{mm;} \mathrm{height} 0.40 \mathrm{~mm}$; left valve : length $0.7 \mathrm{I} \mathrm{mm}$; height $0.43 \mathrm{~mm}$. Type locality: reef off Honolulu, 40 fathoms, July I875.

Description. Shape as described by Brady (I880) for left valve. See Pl. 5, fig. 3 for right valve. Ornamentation as given by Brady (I880) Inner lamella: narrow marginal area, vestibule widest at anterior, narrows greatly at ventral sinus (right valve) increases in width again posterior to ventral sinus, then disappears about mid-posterior. See Pl. 5, figs I and 3. Hinge adont. Normal pores open, evenly distributed. Central muscle scars about twelve, very irregularly shaped scars. See Pl. 5, fig. 2.

\section{Bairdia fortificata Brady}

(P1. 5, figs 7-9)

Bairdia fortificata Brady, 1880 : 59, pl. II, figs 4 a-b.

Lectotype. Left valve, BM 8I.5.I2. Length I.09 mm; height $0.56 \mathrm{~mm}$. Type locality: Stat. 187 , off Booby Island, north of Australia. $\left(10^{\circ} 36^{\prime} \mathrm{o}^{\prime \prime} \mathrm{S}, 14 \mathrm{I}^{\circ} 55^{\prime} \mathrm{o}^{\prime \prime} \mathrm{E}\right.$, dredged, 6 fathoms, coral mud, surface temp. $77 \cdot 7^{\circ} \mathrm{F}$, September 9, I874.)

Description. Shape as given by Brady (I880). See Pl. 5, fig. 7. Ornamentation: see Pl. 5, figs 7 and 8. Inner lamella: marginal zone wide, vestibule very 
reduced and restricted to anterior and posterior extremities. Marginal pore canals simple, straight and numerous. Hinge adont. Left valve with straight, smooth groove. Central muscle scars: see Pl. 5, fig. 8.

REMARKs. The only specimen of this species (a left valve) found by Brady (I880, p. 59) is designated lectotype. Two left valves and a complete carapace were recovered from sediment sample M-242 (Stat. I87). Topotypic material: two left valves, BM I974.27I-272.

\title{
Bairdia globulus Brady \\ (Pl. 4, figs 6-II)
}

Bairdia globulus Brady, I880: 54, pl. 9, figs ra-d.

LECTOTYPE. Right and left valves of an articulated specimen, BM 80.38.34 (separated after photography). Right valve: length $\mathrm{r} .05 \mathrm{~mm}$; height $0.62 \mathrm{~mm}$; left valve: length $\mathrm{I} .09 \mathrm{~mm}$; height $0.7 \mathrm{I} \mathrm{mm}$. Type locality: Nares Harbour, Admiralty Islands, I6 fathoms, March 2, I875.

Description. Shape as described by Brady (I880) for left valve. Notable differences between the description by Brady and the left valve of the lectotype include the anterior extremity, the latter not being 'very broadly rounded', absence of teeth at the anterior end and their presence on the posteroventral end, the ventral margin not being considerably arched and the height of the left valve being closer to two-thirds of the length, rather than three-fourths. See Pl. 4, fig. 6 for other features of left valve and $\mathrm{Pl}$. 4, figs 8 and 9 for shape of right valve. Ornamentation: 'distinct small impressed puncta' of Brady not present on lectotype. Inner lamella: see Pl. 4, figs 6 and 8. Marginal pore canals simple and straight. Hinge: right valve with weak terminal teeth. Normal pores open, evenly distributed. Central muscle scars: see Pl. 4, fig. Io.

\section{Bairdia hirsuta Brady}

\author{
(Pl. 4, figs 4, 5)
}

Bairdia hirsuta Brady, 1880 : 50, 51, pl. 8, figs 3a-d.

Lectotype. Right valve, BM 80.38.35. Length I.46 mm; height $0.90 \mathrm{~mm}$. Type locality: Stat. 300, near Juan Fernandez Island, west of Chile, I375 fathoms. $\left(33^{\circ} 42^{\prime} \mathrm{o}^{\prime \prime} \mathrm{S}, 78^{\circ} \mathrm{Io}^{\prime} \mathrm{o}^{\prime \prime} \mathrm{W}\right.$, trawled, Globigerina ooze, bottom temp. $35^{\circ} 5^{\circ} \mathrm{F}$, surface temp. $62.5^{\circ} \mathrm{F}$, December I7, I875.)

Description. Shape as given by Brady (I880). Ornamentation: smooth and glossy, hairy. Inner lamella: marginal zone well developed, anterior and posterior vestibula equal in size. Hinge adont. Central muscle scars: anteriorly, three elongated scars arranged vertically, plus a single posterior scar. 


\section{Bairdia minima Brady}

(Pl. 3, figs I7, I8; Pl. 4, figs I-3)

Bairdia minima Brady, 1880 : 53, pl. 7, figs 6a-g.

LEctotype. Right and left valves of a complete carapace, BM 80.38.37. Right valve : length $0.65 \mathrm{~mm}$; height $0.39 \mathrm{~mm}$; left valve : length $0.63 \mathrm{~mm}$; height $0 \cdot 40 \mathrm{~mm}$. Type locality: Port Jackson, Australia, 6 fathoms, April 20, I874.

Description. Shape as described by Brady (I880) for left valve. See Pl. 3, fig. I8, for details of right valve. Ornamentation as given by Brady (I880). Inner lamella : marginal area very narrow. Hinge: right valve 'toothless'. Normal pores open and numerous, especially numerous outside the central muscle scar field. Central muscle scars: see Pl. 4, fig. 2. The right valve has eight scars, the left valve nine, each valve having two frontal and two mandibular scars.

\section{Bairdia simplex Brady}

(P1. 3, figs II-I4)

Bairdia simplex Brady, 1880 : 5 I, pl. 7 , figs ra-d.

Lectotype. Right and left valves of a complete carapace, BM 8I.5.I3. Right valve: length $0.49 \mathrm{~mm}$; height $0.78 \mathrm{~mm}$; left valve : length $\mathrm{I} .49 \mathrm{~mm}$; height $0.8 \mathrm{I} \mathrm{mm}$. Type locality: Stat. I5I, off Heard Island, 75 fathoms. ( $52^{\circ} 59^{\prime} 30^{\prime \prime} \mathrm{S}$, $73^{\circ} 33^{\prime} 30^{\prime \prime} \mathrm{E}$, dredged, volcanic mud, surface temp. $36 \cdot 2^{\circ} \mathrm{F}$, February $7, \mathrm{I} 874$.)

Description. Shape as described by Brady (I880) for left valve. See Pl. 3, figs II and I2 for left valve and figs $\mathrm{I}_{3}$ and $\mathrm{I}_{4}$ for right valve. Inner lamella: marginal zone wide, vestibule well developed and widest at anterior end, see Pl. 3, figs I2 and I4. Marginal pore canals numerous, simple and straight. Hinge: right valve 'toothless'. Normal pores numerous, open and evenly distributed. Central muscle scars: eight somewhat rounded scars in each valve arranged in a circular manner. Mandibular scar appears to be single although it is elongate and constricted near the centre; frontal and other scars distinguishable.

\section{Bairdia villosa Brady}

(Pl. 2, figs I-4)

Bairdia villosa Brady, I88o: 50, pl. 3, figs 3a-b, pl. 5, figs $2 a-g$, pl. 8, figs $4 a-f$.

Leстотуре. Right and left valves of a complete carapace, BM 80.38.44. Right valve : length $\mathrm{I} \cdot 30 \mathrm{~mm}$; height $0.80 \mathrm{~mm}$; left valve: length $\mathrm{I} \cdot 33 \mathrm{~mm}$; height $0.92 \mathrm{~mm}$. Type locality: Stat. I49, Balfour Bay, Kerguelen Island. ( $49^{\circ} 08^{\prime} \mathrm{o}^{\prime \prime} \mathrm{S}$, $70^{\circ} \mathrm{I2}^{\prime} \mathrm{O}$ " E, dredged, 20 fathoms, volcanic mud, January 9, I874.)

Description. Shape essentially as described by Brady (I880). See Pl. 2, figs I and 3. Inner lamella: marginal areas widest anteroventrally. Anterior and posterior vestibula well developed. Marginal pore canals numerous, straight and 
simple. Hinge: right valve 'toothless'. Normal pores open. Central muscle scars: see Pl. 2, fig. 2.

Remarks. Brady (I880, p. 50) reported this species from Stats. I35 and I49; off Christmas Harbour, Kerguelen Island ; off Prince Edward's Island and off Moncœur Island, Bass Strait (Stat. I62). This form is common in sediment sample M-I69 and a left valve and right valve (with appendages) have been obtained. Topotypic material: a right valve, BM I974.269, and a left valve, BM I974.270.

\section{Bairdia woodwardiana Brady}

(P1. 4, figs I6-I8)

Bairdia woodwardiana Brady, I880: 57, 58, pl. II, figs Ia-e.

Lectotype. Right and left valves of a complete specimen, BM 80.38.46. Right valve : length $0.98 \mathrm{~mm}$; height $0.47 \mathrm{~mm}$; left valve : length $0.96 \mathrm{~mm}$; height $0.50 \mathrm{~mm}$. Type locality: Stat. I72, off Tongatabu, I8 fathoms. $\left(20^{\circ} 58^{\prime} \mathrm{o}^{\prime \prime} \mathrm{S}\right.$, I $75^{\circ} \mathrm{Og}^{\prime} \mathrm{o}^{\prime \prime} \mathrm{W}$, dredged, coral mud, surface temp. $75^{\circ} \mathrm{F}$, July 22 , I874.)

Description. Shape essentially as described by Brady (I880). See Pl. 4, figs I6 and I8. Note opaque areas. Ornamentation: surface very finely punctate. Inner lamella: see Pl. 4, figs I6 and I8. Marginal zone widest anteriorly. Anterior vestibule large, posterior very reduced and subparallel to outer margin. Marginal pore canals simple, straight. Normal pores open, numerous, evenly distributed. Central muscle scars: see Pl. 4, fig. I7.

Remarks. Brady found 'about a dozen' (I880, pp. 57, 58) specimens of this species at a single station. Sediment sample M-220 from this Stat. I72 yielded twelve complete carapaces and detached valves. Topotypic material: a complete carapace, BM I974.258, a left valve, BM I974.259, and a right valve, BM I974.260. Additional specimens registered BM I974.26I-8.

\section{Genus CYTHERE}

\section{Cythere acanthoderma Brady}

(Pl. II, figs I6-I8)

Cythere scabra Brady, I 866 (non Münster), I866: 380, pl. 6I, figs $8 \mathrm{a}-\mathrm{d}$.

Cythere acanthoderma Brady, I880: 104, I05, pl. I8, figs 5a-e.

Lectotype. Left valve of a late instar, BM 80.38.48A. Length $0.99 \mathrm{~mm}$; height $0.59 \mathrm{~mm}$. Type locality: Stat. I46, deep sea, east of Prince Edward's Island, I375 fathoms. $\left(46^{\circ} 46^{\prime} \mathrm{o}^{\prime \prime} \mathrm{S}, 45^{\circ} 3 \mathrm{I}^{\prime} \mathrm{o}\right.$ "E, trawled, Globigerina ooze, bottom temp. $35^{\circ} 6^{\circ} \mathrm{F}$, surface temp. $43^{\circ} \mathrm{F}$, December 29 , I873.)

DEscription. Shape and ornamentation as described by Brady (I880). Inner lamella very narrow. Marginal pore canals mostly straight, a few divided marginal pore canals with several false canals. See Pl. II, fig. I7. Hinge holamphidont: 
the hinge in the left valve is not completely developed as the type is a late instar. See Pl. II, fig. I7. Normal pores present. Central muscle scars: four adductor muscle scars vertically arranged, somewhat elongated. The frontal scar is on the anterior edge of the subcentral tubercle and appears as a small transversely elongated scar.

REMARKs. Topotypic material: a complete carapace, BM I974.277, and a right valve, BM I974.276, were found in sediment sample M-I70 (Stat. I46).

\title{
Cythere acupunctata Brady
}

\author{
(Pl. 8, fig. 5)
}

Cythere acupunctata Brady, 1880 : 68, pl. I4, figs Ia-h.

LECtotype. Whole carapace, BM 80.38.50. Right valve: length $0.72 \mathrm{~mm}$; height $0.32 \mathrm{~mm}$; left valve: length $0.72 \mathrm{~mm}$; height $0.32 \mathrm{~mm}$. Type locality: Stat. 233 B, Inland Sea of Japan, I5 fathoms. $\left(34^{\circ} \mathrm{I}^{\prime} \mathrm{o}^{\prime \prime} \mathrm{N}, \mathrm{I} 33^{\circ} 35^{\prime} \mathrm{o}^{\prime \prime} \mathrm{E}\right.$, trawled, I5 fathoms, blue mud, surface temp. $66 \cdot 3^{\circ} \mathrm{F}$, May $26, \mathrm{I} 875$.)

Description. Shape and ornamentation as described by Brady (1880). See P1. 5, fig. 5. Hinge gonglyodont. Central muscle scars: adductor muscle scars consist of four vertically arranged central scars.

REMARKs. Topotypic material: a right valve, BM I974.292.

\section{Cythere arata Brady \\ (Pl. I6, figs 9-Io; Fig. 2)}

Cythere arata Brady, 1880: IoI, pl. 24, figs 2a-c.

LECTотуре. Right valve of penultimate instar, BM 80.38.52; designation by Benson (I972, p. 34, pl. II, figs I6, I7). Length $0.96 \mathrm{~mm}$; height $0.53 \mathrm{~mm}$. Type locality: Stat. I67, west of New Zealand, I5o fathoms. $\left(39^{\circ} 32^{\prime} \mathrm{o}^{\prime \prime} \mathrm{S}, \mathrm{I}_{7 \mathrm{I}^{\circ}} 48^{\prime} \mathrm{o}^{\prime \prime} \mathrm{E}\right.$, trawled, blue mud, surface temp. $58 \cdot 5^{\circ} \mathrm{F}$, June 24 , I874.)

DESCRIPTION. Shape and ornamentation as described by Brady (I880). See Pl. r6, fig. Io. Inner lamella: anterior and posterior vestibula present but poorly developed. The posterior vestibule is as wide as the anterior one but not as long. The limits of the anterior vestibule are not defined. Marginal pore canals: posterior end has several canals whose endings are indistinct. Anteriorly, the canals are more evenly spaced, but more obscure; this is particularly true on the ventral side where their vague image can be seen along the edge. Central muscle scars: a vertical row of four and frontal scar (see Fig. 2). Hinge highly modified, antimerodont type; the anterior crenulate tooth is present. The median groove is only slightly crenulate, a slightly raised area with two points on the ends exists in the middle of the groove. The posterior tooth is smaller than the anterior tooth and is slightly crenulate.

Remarks. Cythere arata Brady is the type species of Bradleya, Hornibrook, I952. 


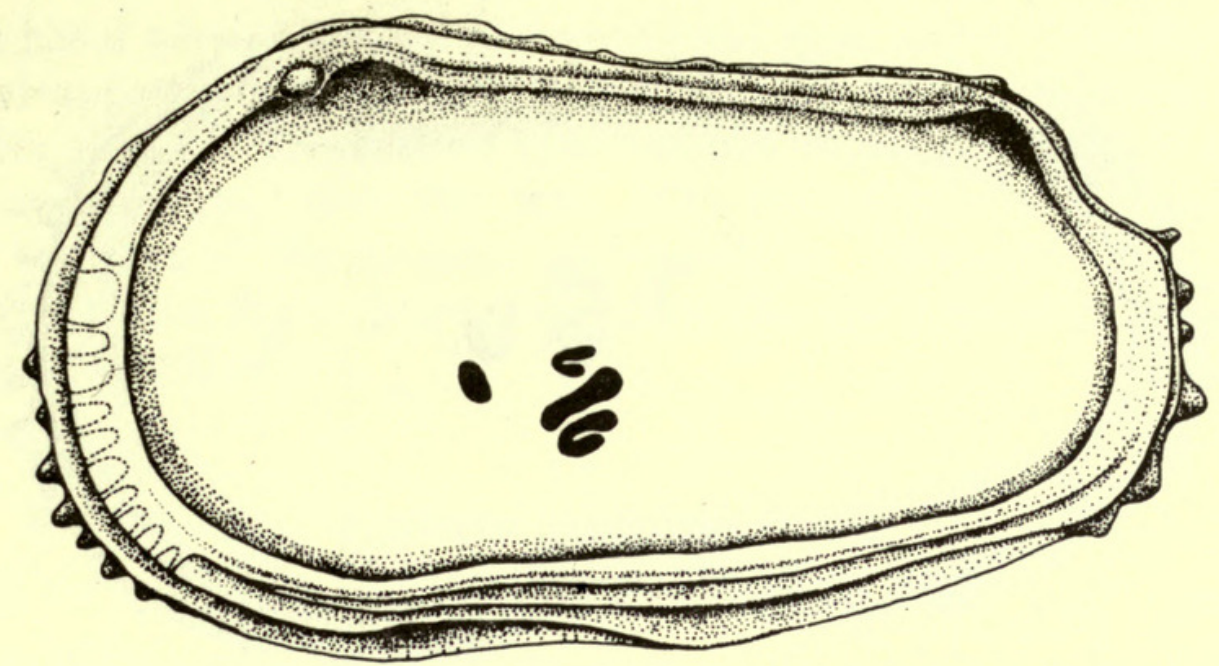

FIG. 2. Cythere arata Brady: interior view of lectotype ( $\times 92)$.

\section{Cythere bicarinata Brady}

(P1. I0, figs I2, I3)

Cythere bicarinata Brady, 1880 : 70, pl. 16, figs 6a-d.

Lectotype. Whole carapace, BM 80.38.50. Right valve: length $0.63 \mathrm{~mm}$; height $0.27 \mathrm{~mm}$; left valve : length $0.63 \mathrm{~mm}$; height $0.28 \mathrm{~mm}$. Type locality: Stat. $233 \mathrm{~B}$, Inland Sea of Japan, I5 fathoms. $\left(34^{\circ} 20^{\prime} \mathrm{o}^{\prime \prime} \mathrm{N}, \mathrm{I} 33^{\circ} 35^{\prime} \mathrm{o}^{\prime \prime} \mathrm{E}\right.$, trawled, I5 fathoms, blue mud, surface temp. $66 \cdot 3^{\circ} \mathrm{F}$, May $26, \mathrm{I} 875$.)

Description. Shape and ornamentation: see Brady (I880) and Pl. Io, figs I2 and 13 .

Remarks. Topotypic material: a left valve, BM I974.282, and a right valve, BM I974.28r.

\section{Cythere circumdentata Brady}

(P1. I7, figs 3-6; Fig. 3)

Cythere circumdentata Brady, 1880: 106, pl. 26, figs 2a-c.

Lестотуре. Left valve, probably a penultimate stage, BM 80.38.58. Length I.2I mm ; height $0.68 \mathrm{~mm}$. Type locality: Stat. 276 , off the northwestern end of the Tuamotu Archipelago, 2350 fathoms. $\left(3^{\circ} 28^{\prime} \mathrm{o}^{\prime \prime} \mathrm{S}, \mathrm{I} 49^{\circ} 30^{\prime} \mathrm{o}^{\prime \prime} \mathrm{W}\right.$, trawled, red clay, bottom temp. $35 \cdot \mathrm{I}^{\circ} \mathrm{F}$, surface temp. $80^{\circ} \mathrm{F}$, September I6, I875.)

DEsCRIPTION. Shape and ornamentation as described by Brady (I880). Inner lamella: two vestibula of which the anterior vestibule is the larger. Marginal pore canals: only one straight and unbranched canal visible in the anterior region. Hinge amphidont, see Fig. 3. Normal pores scattered over the surface with more in the anterior and central regions. Most of the pores appeared to be open but several show resemblance to a sieve type. Central muscle scars: four vertically arranged adductor scars of which the uppermost scar is rather obscure. The dorsal 


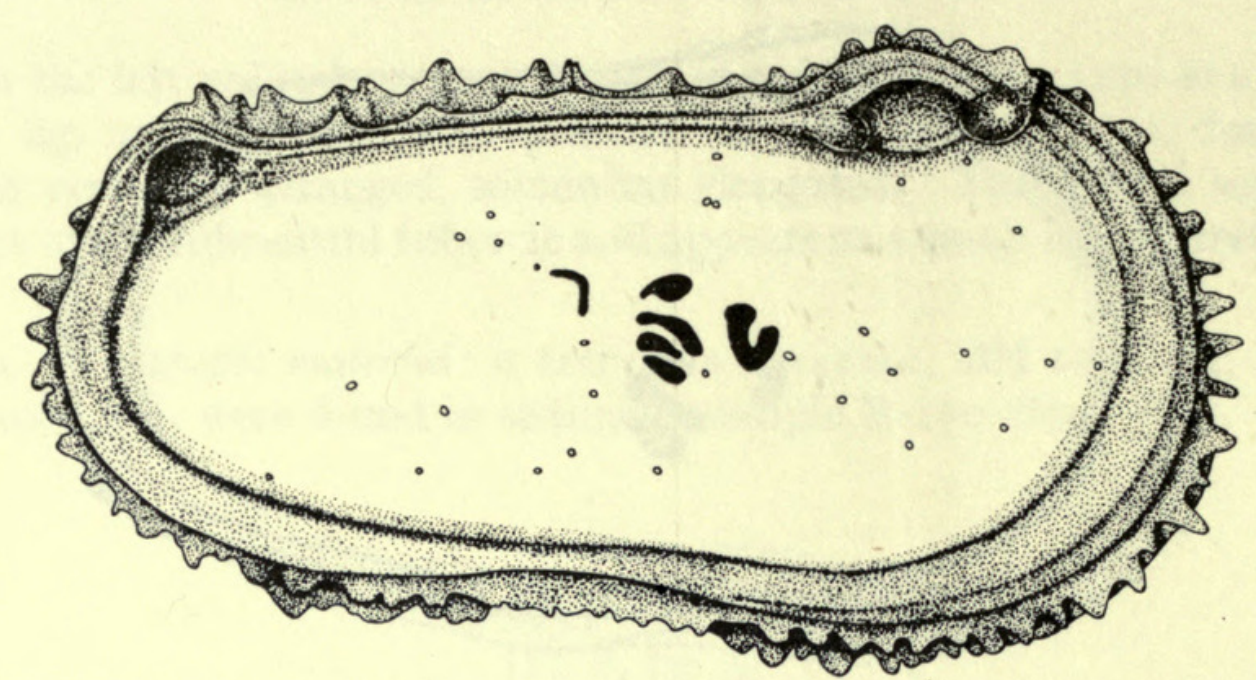

FIG. 3. Cythere circumdentata Brady: interior view of lectotype $(\times 73)$.

middle scar is flattened $U$-shape with the largest end extending over the scars beneath. Frontal scar V-shaped. A small dumb-bell shaped scar in the dorsal muscle scar field is present behind the adductor scars (see Fig. 3).

\section{Cythere clavigera Brady}

(Pl. I6, figs I, 2 ; Fig. 4)

Cythere clavigera Brady, 1880 : 109, I10, pl. 23, figs 7a-d.

Lectotype. Right valve (moult), BM 80.38.59. Length $0.90 \mathrm{~mm}$; height $0.47 \mathrm{~mm}$. Type locality: Port Jackson, Australia, 2-Io fathoms, April 20, I874.

Description. Shape and ornamentation as described by Brady (I880). Inner lamella: the area is so restricted in width that vestibula are non-existent. Marginal pore canals: none observed. Hinge modified between the antimerodont and hemimerodont types ; the anterior end consists of a flat, smooth tooth which is somewhat

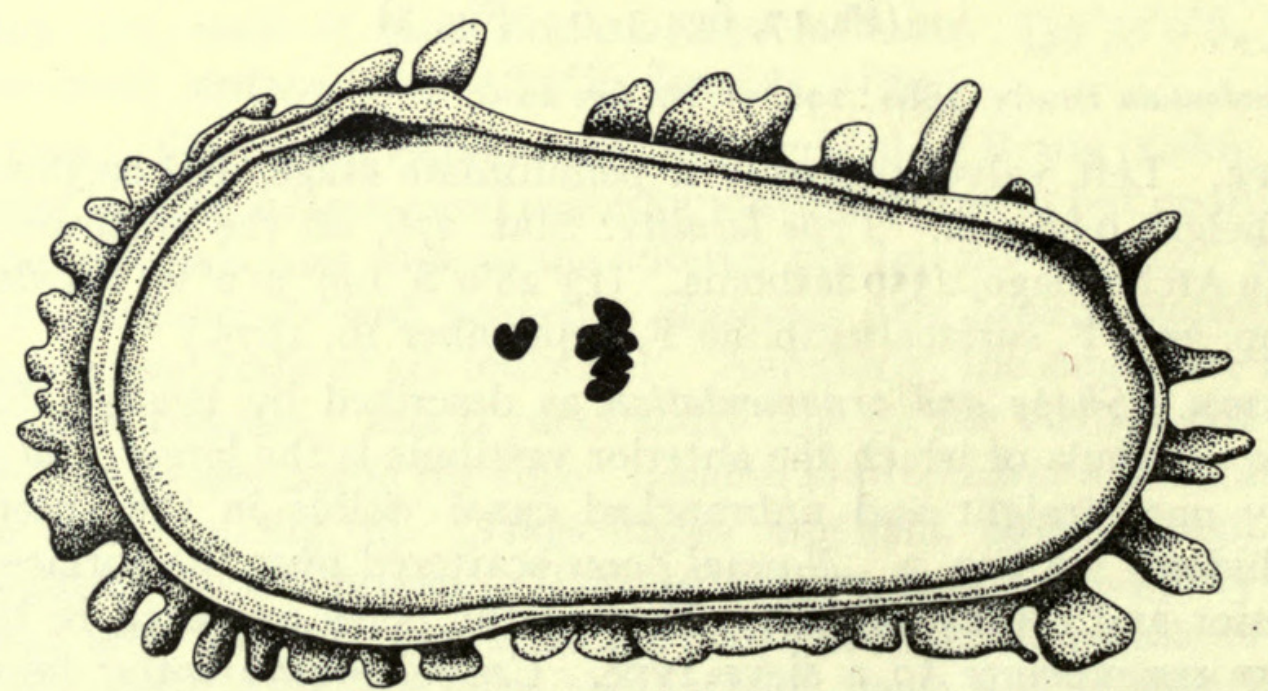

FIG. 4. Cythere clavigera Brady: interior view of lectotype $(\times 92)$. 
rounded and has a very slight crenulation on the right valve. See Fig. 4. Normal pores: several apparent sieve types. Central muscle scars: adductor muscle scars four in number with the two bottom scars fused into one ; the middle scar is square on one end and is larger than the rest. The frontal scar is V-shaped, partially obscured by the base of the external protuberance. There are two round scars in the dorsal area and a slight depression below the eye spot area of the side. See Fig. 4. Eyespot prominent.

\section{Cythere craticula Brady}

(Pl. I4, figs 9-I2)

Cythere craticula Brady, 1880: 89, pl. 21, figs 7a-d.

Lectotype. Left valve, BM 8r.5.I6. Length $0.74 \mathrm{~mm}$; height $0.34 \mathrm{~mm}$. Type locality: Stat. I40, Simon's Bay, South Africa, I5-20 fathoms, October I873.

Description. Shape and ornamentation: see Brady (I880) and Pl. I4, figs 9 and Io. Marginal pore canals: both anterior and posterior ends have numerous mostly straight pores; a few false pore canals are present. At the anterior margin one canal is branched and a few are curved. Hinge holamphidont. See Pl. I4, fig. II. Eyespots present, but not well developed.

\section{Cythere cristatella Brady}

(Pl. 26, figs 5 and 7)

Cythere cristatella Brady, I880: 9o, pl. 19, figs 6a-d.

Lectotype. Complete carapace, BM 80.38.63. Length $0.65 \mathrm{~mm}$; height $0.37 \mathrm{~mm}$. Type locality: Stat. I87, off Booby Island, 6-8 fathoms.

Description. Shape and ornamentation as given by Brady (I880). See Pl. 26, figs 5 and 7 .

Remarks. Brady (I880, p. 90) described this species from only one locality (Stat. I87). Of several specimens present in sediment sample M-242, two are figured on $\mathrm{Pl}$. 26, figs 5 and 7 . Topotypic material: two complete carapaces, BM I974.I84-5.

\section{Cythere cumulus Brady}

(Pl. 6, figs I3-I8; Pl. 7, fig. 5 ; Fig. 5)

Cythere cumulus Brady, I880: 7I, pl. I3, figs 2a-d.

Leстотуре. Disarticulated left and right valves, BM 8I.5.I7 (separated after photography). Right valve: length $0.50 \mathrm{~mm}$; height $0.28 \mathrm{~mm}$; left valve : length $0.50 \mathrm{~mm}$; height $0.28 \mathrm{~mm}$. Type locality: Port Jackson, Australia, 2-IO fathoms, April 20, I874. 


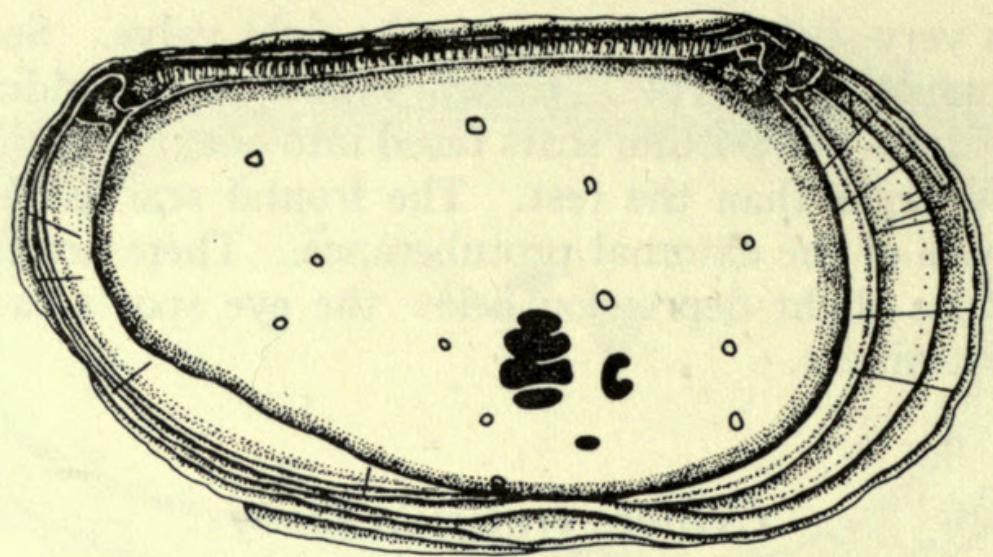

FIG. 5. Cythere cumulus Brady : interior (disarticulated) left valve view of lectotype $\left(\times 1_{5} 0\right)$.

Description. Shape and ornamentation as described by Brady (I880). See Pl. 6, figs I3, I4 and I7. Inner lamella: anterior vestibule much wider than posterior vestibule present only on the lower half of the posterior end. Marginal pore canals few, straight to slightly curved, widely spaced anterior and posterior marginal pore canals. See Pl. 6, figs I6 and I7 and Fig. 5. Hinge gongylodont. See Pl. 6, figs I6 and 18 and Fig. 5. Normal pores of sieve type with two configurations; the more regular pore type and pores which seem to be linear openings in the sieve. Central muscle scars: adductor muscle scars, four, elongated, closely stacked, forming a crescent-shaped outline. A frontal scar is present in a somewhat flattened area (see Fig. 5).

Remarks. Sediment sample M-I98 (Port Jackson, Australia, 2-Io fathoms) yielded several specimens of this species. Topotypic material: a complete carapace, a right valve and two left valves, BM I974.343-46.

\section{Cythere curvicostata Brady}

(P1. 5, figs I6-I9)

Cythere curvicostata Brady, $1880: 84,85$, pl. I2, figs 4 a-d.

Lectotype. Whole carapace, BM 80.38.64. Length $0.59 \mathrm{~mm}$; height $0.34 \mathrm{~mm}$. Type locality: Stat. $\mathrm{I} 87$, off Booby Island, 6 fathoms. $\left(\mathrm{Io}^{\circ} 36^{\prime} \mathrm{o}^{\prime \prime} \mathrm{S}\right.$, $\mathrm{I}_{4} \mathrm{I}^{\circ} 55^{\prime} \mathrm{o}^{\prime \prime} \mathrm{E}$, dredged, coral sand, surface temp. $77 \cdot 7^{\circ} \mathrm{F}$, September 9, I874.)

Description. Shape and ornamentation as described by Brady (I880). Hinge holamphidont.

\section{Cythere cytheropteroides Brady}

(Pl. 9, figs $5-8$ )

Cythere cytheropteroides Brady, $1880: 78$, pl. 15, figs 5a-d.

Lectotype. Right valve, BM 80.38.67. Length $0.89 \mathrm{~mm}$; height $0.56 \mathrm{~mm}$. Type locality: Stat. I42, off Cape of Good Hope, I 50 fathoms. $\left(35^{\circ}{ }^{\circ} 4^{\prime \prime} \mathrm{S}\right.$, I $8^{\circ} 37^{\prime} \mathrm{o}^{\prime \prime} \mathrm{E}$ dredged, sand, bottom temp. $47 \cdot 0^{\circ} \mathrm{F}$, surface temp. $65 \cdot 5^{\circ} \mathrm{F}$, December I8, I873.) 
Description. Shape and ornamentation: see Brady (I880) and Pl. 9, figs 5 and 7 . Inner lamella: the anterior and posterior vestibula are not well developed. Hinge hemiamphidont. See Pl. 9, figs 6 and 8. The anterior element is a worn tooth. Posterior tooth or lobe is broken and the median groove is worn so that crenulations cannot be seen. Central muscle scars: adductor muscle scars consist of four vertically stacked scars. One small V-shaped frontal scar is present.

REMARKs. A complete carapace and a right valve were found in sediment sample M-I66 (Stat. I42). Topotypic material: a complete carapace and a right valve, BM I974.333-4.

\title{
Cythere dasyderma Brady
}

\author{
(Pl. II, figs IO, II)
}

Cythere dasyderma Brady, I880 : 105, 106, pl. I7, figs 4a-f; pl. I8, figs 4a-f.

LECTOTYPE. Left valve (probably a penultimate stage), BM I96I.I2.4.39. Length I.20 mm ; height $0.7 \mathrm{I} \mathrm{mm}$. Type locality: Stat. $296 . \quad\left(38^{\circ} 6^{\prime} 0^{\prime \prime} \mathrm{S}, 88^{\circ} 2^{\prime} \mathrm{o}^{\prime \prime} \mathrm{W}\right.$, I825 fathoms, bottom temp. $I \cdot 2^{\circ} \mathrm{C}$, red clay, November $\left.9, \mathrm{I} 875.\right)$

DESCRIPTION. Shape and ornamentation: see Brady (I880). Hinge holamphidont (imperfect). The anterior tooth and the anterior and posterior pits are not well developed. Central muscle scars: four adductor muscle scars are arranged vertically with a single frontal scar.

Remarks. Brady described this species from 20 stations, including Stat. 296. The lectotype is from Stat. 296 and is probably a penultimate stage of left valve. A right valve was found in sediment sample M-237 (Stat. I85). Brady (I880) figured four complete carapaces, one from Stat. 3I7 (pl. I7, figs $4 \mathrm{a}-\mathrm{d}$ ) and the second from Stat. I22 (pl. I7, figs 4e, f) ; the third from Stat. 246 (pl. I8, figs 4a-d) and the fourth from Stat. 300 (pl. I8, figs 4e, f). Topotypic material: right valve, BM I974.275 (Stat. I85, Torres' Straits, I55 fathoms, sand, August 3I, I874).

\section{Cythere dictyon Brady}

(Pl. I6, figs 6-8; Fig. 6)

Cythere dictyon Brady, I880: 99-101, pl. 24, figs ra-y.

Lectotype. Left valve, BM I96I.I2.4.32; designation by Benson (I972, p. 36, pl. II, fig. I8) ; see Fig. 6 . Length I.24 mm ; height $0.53 \mathrm{~mm}$. Type locality: Stat. 78 . $\left(37^{\circ} 26^{\prime} 0^{\prime \prime} \mathrm{N}, 25^{\circ} \mathrm{I} 3^{\prime} \mathrm{o}^{\prime \prime} \mathrm{W}\right.$, dredged, rooo fathoms, surface temp. $7 \mathrm{r} \cdot 0^{\circ} \mathrm{F}$, July I0, I873.)

DESCRIPTION. Shape and ornamentation as described by Brady (I880). Inner lamella: both the anterior and posterior vestibula are well developed. Marginal pore canals numerous, unevenly spaced, bifurcated, trifurcated, and straight (see Fig. 6). Hinge holamphidont. The left valve with an anterior socket and tooth, a median, slightly crenulate bar and a posterior socket. See Fig. 6. Normal pores numerous, occupying positions in the centre of the reticulations. Some appear to be 


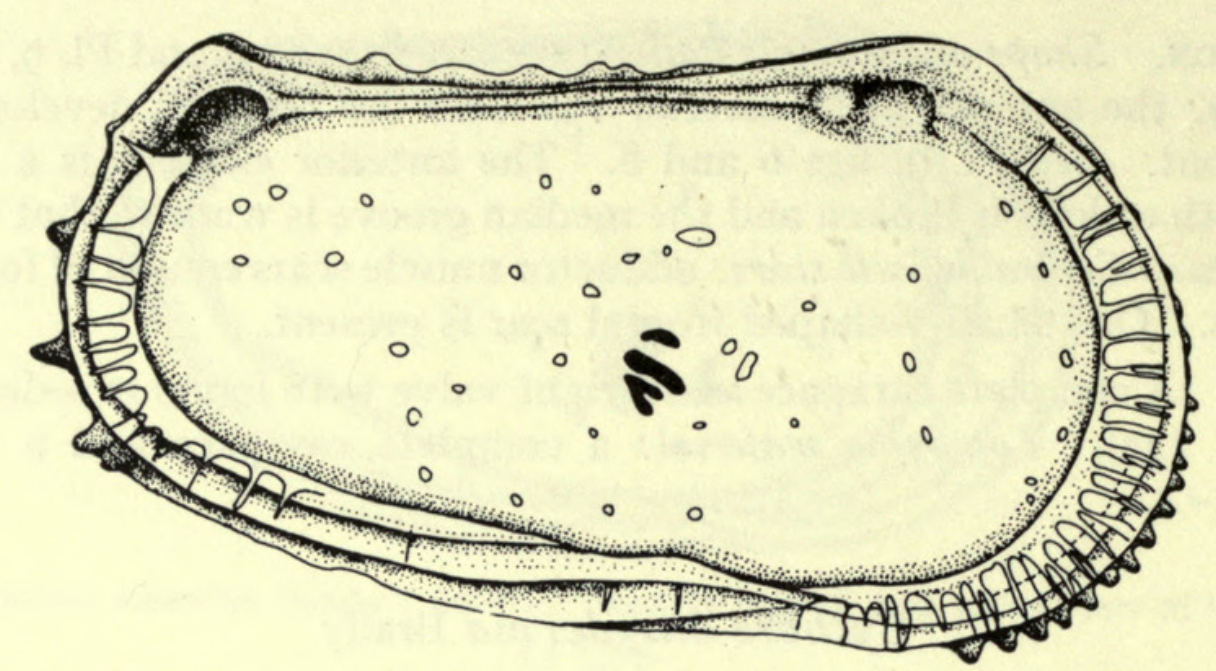

FIG. 6. Cythere dictyon Brady: interior view of lectotype $(\times 70)$.

sieve types but others are indefinite and may be open normal pores. Central muscle scars: the adductor muscle pattern consists of four scars vertically arranged. The lower two are fused to form a V-shaped scar. The ventral scar touches the middle scar, the dorsal scar is elongate and separated from the rest. The frontal scar is divided into separate scars, one circular and the other cylindrical in shape. There are two scars visible in the dorsal muscle field.

Remarks. Humboldt Bay, Papua, 37 fathoms (M-277) is one of the many localities Brady (I880) reported this species to occur. Five specimens are from this station where the species is common. Topotypic material: a left valve, BM I974.293, right valve, BM I974.294, a left valve, BM I974.295, a right valve, BM I974.296, and a complete carapace, BM I974.297.

\section{Cythere dorsoserrata Brady}

(Pl. I5, figs I-4)

Cythere dorsoserrata Brady, I880 : 102, 103, pl. 23, figs Ia-d (dorsiserrata on pl. 23, figs 1a-d).

Lectotype. Right valve, BM 8I.5.I9. Length $0.56 \mathrm{~mm}$; height $0.47 \mathrm{~mm}$. Type locality: Stat. 335 , north of Tristan d'Acunha. $\left(32^{\circ} 24^{\prime} \mathrm{o}^{\prime \prime} \mathrm{S}, \mathrm{I}^{\circ} 5^{\prime} \mathrm{o}^{\prime \prime} \mathrm{W}\right.$. I 425 fathoms, bottom temp. $2 \cdot 3^{\circ} \mathrm{C}$, Globigerina ooze, March I6, I876.)

Description. Shape and ornamentation: see Brady (I880). Inner lamella: both the anterior and posterior vestibula are well developed. The anterior vestibule is long and narrow ; the posterior one is shorter but its width gradually increases to a point where it is wider than the anterior vestibule. Marginal pore canals: the anterior pores are generally straight, a few are bifurcated. False pore canals are particularly numerous anteriorly ; several straight canals are present but most are rather obscure. Hinge holamphidont. Right valve with a two-level cardinal tooth anteriorly, a mid-hinge groove that is coarsely crenulated anteriorly and changes at the mid-point and becomes smooth, and a posterior tooth which is broad, flat and smooth. Central 
muscle scars: the adductor muscles are placed vertically with two flat bars on the top, the bottom two are fused to form an upside-down triangle. The entire group has a forward slant. The frontal muscle scar is V-shaped with the top of the arms of the $\mathrm{V}$ poorly visible.

\section{Cythere ericea Brady}

(Pl. Io, figs I4-I8)

Cythere ericea Brady, I880: 107, pl. I7, figs Ia-d.

Lectotype. Right valve, BM 80.38.76. Length $\mathrm{I} \cdot \mathrm{I} 3 \mathrm{~mm}$; height $0.7 \mathrm{I} \mathrm{mm}$. Type locality: Stat. I20, off Pernambuco. $\left(8^{\circ} 37^{\prime} \mathrm{o}^{\prime \prime} \mathrm{S}, 34^{\circ} 28^{\prime} \mathrm{o}^{\prime \prime} \mathrm{W}, 675\right.$ fathoms, trawled, mud, surface temp. $28 \cdot 0^{\circ} \mathrm{F}$, September 9, I873.)

Description. Shape and ornamentation as described by Brady (1880). Inner lamella: vestibula present at both anterior and posterior ends; anterior vestibule larger than posterior one. Marginal pore canals straight, few and widely spaced. Hinge lophodont. Right valve with anterior and posterior tooth with slightly crenulated groove between. Central muscle scars very prominent with the adductor muscle consisting of four vertically arranged elongated scars with the dorsal scar slightly tipped away.

Remarks. Brady (I880, p. I07) found this species at only one station (Stat. I20) and figured two left valves, one ornamented with spines (pl. I7, figs Ia-c) and the other denuded of spines (pl. I7, fig. Id). Sediment sample M-I40, which represents this station yielded a right valve. Topotypic material: a right valve, BM I974.283.

\section{Cythere exfoveolata Neviani}

(P1. 7, figs I6-I9)

Cythere foveolata Brady, 1880: 75, 76, pl. 13, figs 5a-h.

non Cythere foveolata Sequenza, 1880: 324, pl. 17, fig. 23.

Cythere exfoveolata Neviani, I928 : 106 (new name for C. foveolata Brady).

Lectotype. Whole carapace, male, BM 80.38.8I. Right valve: length $0.62 \mathrm{~mm}$; height $0.3 \mathrm{I} \mathrm{mm}$; left valve : length $0.62 \mathrm{~mm}$; height $0.3 \mathrm{I} \mathrm{mm}$. Type locality: Stat. 5I, off Heard Island, 75 fathoms. $\left(52^{\circ} 59^{\prime} 30^{\prime \prime} \mathrm{S}, 73^{\circ} 33^{\prime} 30^{\prime \prime} \mathrm{E}\right.$, dredged, mud, surface temp. $36 \cdot 2^{\circ} \mathrm{F}$, February 7 , I874.)

Description. Shape and ornamentation as described by Brady (I880). See Pl. 7, figs I6, I7 and I9. Eyespots present, as upraised tubercles. Inner lamella: not observed. Marginal pore canals: none observed. Hinge: not observed.

Remarks. Brady (I88o, pp. 75, 76) reported this from two stations (Stat. I49 and $\mathrm{I}_{5} \mathrm{I}$ ) and figured complete carapaces of a female (pl. I3, figs $5 \mathrm{a}-\mathrm{d}$ ) and a male (pl. I3, figs $5 \mathrm{e}-\mathrm{h}$ ). The lectotype is from off Heard Island (Stat. I5I) and a single left valve, which represents a female, was recovered from sediment sample M-I85, which represents Stat. I5I. Topotypic material: a left valve, BM I974.288. 


\section{Cythere exilis Brady}

(Pl. Io, figs I-II)

Cythere exilis Brady, $1880: 69$, pl. 16, figs 5a-h.

Lectotype. Disarticulated right and left valves, BM 81.5.20. Right valve : length $0.87 \mathrm{~mm}$; height $0.37 \mathrm{~mm}$; left valve : length $0.87 \mathrm{~mm}$; height $0.39 \mathrm{~mm}$. Type locality: Stat. I40, Simon's Bay, South Africa, $15-20$ fathoms, October I873.

Description. Shape and ornamentation as described by Brady (I880). See Pl. Io, figs I, 3. Marginal pore canals numerous, few curved, others straight. Hinge holamphidont, see Pl. Io, figs 9-II. Normal pores present, but type unclear. Central muscle scars: three adductor scars, one round frontal scar. Overlap: left valve is larger than the right valve.

Remarks. Brady (I880, p. 69) found this species at only one station (Stat. I40) and figured a complete female carapace (pl. I6, figs 5a-d) and a male (pl. I6, figs $\mathrm{e}-\mathrm{h})$. A complete carapace, a right valve and a left valve (moult) were recovered from sediment sample M-I64. Topotypic material: a complete carapace, BM I974.278, a right valve, BM I974.279, and a left valve, BM I974.280.

\section{Cythere falklandi Brady}

(P1. 6, figs 4-9)

Cythere falklandi Brady, 1880 : 65-66, pl. I2, figs 6a-f.

Leстотуре. Left valve, BM 80.38.78.A. Length $0.65 \mathrm{~mm}$; height $0.28 \mathrm{~mm}$. Type locality: Stat. $3 \mathrm{I} 6$, Stanley Harbour, Falkland Islands, 6 fathoms. $\quad\left(5 \mathrm{I}^{\circ} 32^{\prime} \mathrm{o}\right.$ "S, $5^{\circ} 06^{\prime} \mathrm{o}^{\prime \prime} \mathrm{W}$, anchor mud, surface temp. $5 \mathrm{I} \cdot 2^{\circ} \mathrm{F}$, February I, I876.)

DESCRIPTION. Shape and ornamentation as given by Brady (I880). Inner lamella: the vestibule extends from the dorsal portion of the carapace near the anterior end of the hinge along the ventral edge narrowing at a point below the muscle scars and widening again as it follows through to the posterior end of the hinge. The anterior vestibule is wider than the posterior vestibule. Marginal pore canals few, straight, widely spaced. Hinge modified entomodont.

\section{Cythere flabellicostata Brady}

(P1. 8, figs I-4)

Cythere flabellicostata Brady, $1880: 88,89$, pl. 13, figs 6a-h.

Lectotype. Disarticulated left and right valves, BM 80.38.79. Right valve : length $0.75 \mathrm{~mm}$; height $0.37 \mathrm{~mm}$; left valve : length $0.75 \mathrm{~mm}$; height $0.37 \mathrm{~mm}$. Type locality: Stat. I40, Simon's Bay, South Africa, I5-20 fathoms, October 1873.

DEscription. Shape and ornamentation: see Brady (I880) and Pl. 8, figs I-4. Inner lamella: the anterior and posterior vestibula are well developed with the former being the best developed. Marginal pore canals usually straight, although a few are branched, closely spaced, numerous marginal pore canals with a few false canals 
mostly at the posterior end. Hinge holamphidont (modified). Right valve in the anterior part has a tooth adjacent to a large antero-median socket, a corresponding tooth on the left valve. Posteriorly, the right valve has a lobed tooth. Left valve has a crenulated median bar. Normal pores of open type. Overlap: left valve larger than the right valve.

Remarks. Brady $(\mathrm{I} 880$, pp. 88,89$)$ found this species only at Simon's Bay station and figured a complete female carapace (pl. I3, figs 6a-d) and a male carapace (pl. I3, figs $6 \mathrm{e}-\mathrm{j}$ ). Sediment sample M-I64 yielded three valves, a male left and right valve and one female left valve. Topotypic material: a left valve, BM I974.3I5, a right valve, BM I974.3I6, and a left valve, BM I974.3I7.

\section{Cythere floscardui Brady}

$$
\text { (Pl. 7, figs } \mathrm{I}-4,6,7 \text { ) }
$$

Cythere floscardui Brady, I880: 71, 72, pl. I3, figs 3a-h.

Lectotype. Whole carapace, BM 80.38.80. Right valve: length $0.40 \mathrm{~mm}$; height $0.25 \mathrm{~mm}$; left valve : length $0.40 \mathrm{~mm}$; height $0.25 \mathrm{~mm}$. Type locality: Stat. 246, reefs off Honolulu, 40 fathoms, July I875.

Description. Shape and ornamentation as described by Brady (I880). See also Pl. 7, figs I, 3, 4, 7. Central muscle scars: see Pl. 7, fig. 2. Eyespots very slightly hyaline.

Remarks. Brady (I880, pp. $7 \mathrm{I}, 72$ ) found this species occurring off reefs, Honolulu (Stat. 246). He figured a complete carapace of (?) female (pl. I3, figs $3 \mathrm{a}-\mathrm{d}$ ) and a (?) male (pl. I3, figs $4 \mathrm{e}-\mathrm{h}$ ). A female left valve recovered here from sediment sample M-324 (Stat. 246) where this species is common. Topotypic material: a female left valve, BM I974.287.

\section{Cythere fulvotincta Brady}

(P1. 8, figs I0-I2)

Cythere fulvotincta Brady, $1880: 67$, pl. I4, figs 5a-d.

Lectotype. Whole carapace, BM 8I.5.2I. Right valve: length $0.68 \mathrm{~mm}$; height $0.37 \mathrm{~mm}$; left valve: length $0.68 \mathrm{~mm}$; height $0.37 \mathrm{~mm}$. Type locality: Stanley Harbour, Falkland Islands, 6 fathoms.

Description. Shape as described by Brady (I880). Ornamentation: see Pl. 8, figs Io and I2. Eyespots present but not well developed. Overlap: none.

Cythere hardingi nom. nov.

$$
\text { (Pl. 8, figs 8, 9) }
$$

Cythere ovalis Brady, I88o: 66, 67, pl. I4, figs $4 a-d$.

non Cythere ovalis Stoddart, I86I : 489, pl. I8, figs 5, 5A, 5B (Carboniferous, England). 
Lectotype. Whole carapace, BM 80.38.97. Right valve: length $0.74 \mathrm{~mm}$; height $0.34 \mathrm{~mm}$; left valve: length $0.74 \mathrm{~mm}$; height $0.34 \mathrm{~mm}$. Type locality: Stat. I87, off Booby Island, north of Australia, 6-8 fathoms. (10 $36^{\prime} 0^{\prime \prime} \mathrm{S}$, $\mathrm{I}_{4} \mathrm{I}^{\circ} 55^{\prime} \mathrm{o}^{\prime \prime} \mathrm{E}$, dredged, coral and sand, surface temp. $77 \cdot 7^{\circ} \mathrm{F}$, September 9 , I874.)

Description. Shape and ornamentation as described by Brady (I880), see Pl. 8, fig. 8.

\section{Cythere impluta Brady}

(P1. 9, figs $15, \mathrm{I} 6)$

Cythere impluta Brady, $1880: 76,77$, pl. 16, figs 3a-d; pl. 26, figs 6a-d.

Lectotype. Whole carapace (damaged), BM I96r.I2.4.30. Right valve : length $0.73 \mathrm{~mm}$; height $0.45 \mathrm{~mm}$; left valve: length $0.74 \mathrm{~mm}$; height $0.43 \mathrm{~mm}$. Type locality: Stat. 3r6, Stanley Harbour, Falkland Island, 6 fathoms. February, I876.

Description. Shape and ornamentation: See Brady (I880) and Pl. 9, figs I5 and $\mathrm{I} 6$.

\section{Cythere inconspicua Brady}

(P1. 6, figs I0-I2)

Cythere inconspicua Brady, I880: 70, 71, pl. 13, figs ra-d.

Lectotype. Whole carapace, BM 8I.5.22. Right valve: length $0.40 \mathrm{~mm}$; height $0.22 \mathrm{~mm}$; left valve : length $0.40 \mathrm{~mm}$; height $0.21 \mathrm{~mm}$. Type locality: Stat. I85, Torres' Straits, $\mathrm{I} 55$ fathoms. $\left(\mathrm{II}^{\circ} 35^{\prime} 25^{\prime \prime} \mathrm{S}, \mathrm{I} 44^{\circ} \mathrm{O}^{\prime} \mathrm{O}^{\prime \prime} \mathrm{E}\right.$, dredged, sand and shell, surface temp. $77^{\circ} 0^{\circ} \mathrm{F}$, August 3I, I874.)

Description. Shape and ornamentation: see Brady (I880), and Pl. 6, figs Io and $\mathrm{I} 2$.

REMARKs. Brady (I880, pp. 70, 7I) found this species only at one station (Torres' Straits) and figured a complete carapace. A damaged left valve was recovered from sediment sample M-237, which represents Stat. I85. Topotypic material: a damaged left valve, BM I974.286.

\section{Cythere irpex Brady}

(P1. II, figs I-9)

Cythere irpex Brady, 1880 : 107, pl. I7, figs 2a-d.

Lectotype. Left valve, BM 80.38.86. Length $\mathrm{I} \cdot \mathrm{I} 7 \mathrm{~mm}$; height $0.7 \mathrm{I} \mathrm{mm.}$ Type locality: Stat. 73, near Azores, rooo fathoms. $\left(38^{\circ} 30^{\prime} \mathrm{o}^{\prime \prime} \mathrm{N}, 3 \mathrm{I}^{\circ} \mathrm{I} 4^{\prime} \mathrm{o}^{\prime \prime} \mathrm{W}\right.$, dredged, Globigerina ooze, bottom temp. $39 \cdot 4^{\circ} \mathrm{F}$, surface temp. $69 \cdot 0^{\circ} \mathrm{F}$, June $30, \mathrm{I} 873$.) 
Description. Shape and ornamentation as described by Brady (I880). See Pl. II, figs I-4. Inner lamella: vestibula extremely narrow at both the anterior and posterior ends, the anterior vestibule being larger. Marginal pore canals numerous, straight, with a few false canals. Hinge holamphidont (modified). In the left valve, the hinge consists of an anterior socket, a tooth, a slightly crenulated bar, and a larger rounded socket. See Pl. II, figs 6-9. Central muscle scars: see Pl. II, fig. 5 .

REMARKs. Brady (I880, p. IO7) found this species at three stations (Stat. 73, 78 , and 335). He figured a left valve (Brady I880, pl. I7, figs 2a-d) ; the lectotype is a left valve from Stat. 73. A left and a right valve were recovered from sediment sample M-roo. Topotypic material: a right valve, BM I974.273, and a left valve, BM I974.274.

\section{Cythere irrorata Brady}

(Pl. II, figs I2-I4)

Cythere irrorata Brady, 1880 : 108, 109, pl. 28, figs 2a-d.

Lectotype. Whole carapace, BM 80.38.86A. Length $0.74 \mathrm{~mm}$; height 0.40 mm. Type locality: off Admiralty Island, I6-25 fathoms, March 7, I875.

Description. Shape and ornamentation as described by Brady (I880). See Pl. II, figs I2-I4.

\section{Cythere kerguelenensis Brady}

(P1. I2, figs I4-I8)

Cythere kerguelenensis Brady, I880: 78, 79, pl. 4, figs I6-18, pl. 20, figs Ia-f.

Lectotype. Whole specimen, BM 80.38.88. Right valve: length $0.68 \mathrm{~mm}$; height $0.40 \mathrm{~mm}$; left valve: length $0.67 \mathrm{~mm}$; height $0.39 \mathrm{~mm}$. Type locality: Stat. I62, off East Moncœur Island, Bass Strait, 38 fathoms. (39 I0'30"S, $\mathrm{I} 46^{\circ} 37^{\prime} \mathrm{o}^{\prime \prime} \mathrm{E}$, dredged, surface temp. $63 \cdot 2^{\circ} \mathrm{F}$, April 2, I874.)

Description. Shape and ornamentation as described by Brady (I880). See Pl. I2, figs I4-I8.

Remarks. Brady (I880) reported this species from Balfour Bay (20-50 fathoms) ; Royal Sound, Kerguelen Island (28 fathoms) ; off Prince Edward's Island (50-I5O fathoms); off East Moncœur Island (Stat. I62) and Port Jackson, Australia (2-Io fathoms). He figured a complete carapace of a female (pl. 20, figs Ia-c) and of a male (pl. 20, figs Id-f). The lectotype is from Stat. I62. A right valve was recovered from M-I95 (Stat. I62) and a complete carapace from sediment sample M-I69 (off Prince Edward's Island, 50-I50 fathoms). Topotypic material: a whole carapace, BM I974.3I3, and a right valve, BM I974.3I4. 
Cythere (?) laganella Brady, $1880: 63$, pl. 16 , figs $7 \mathrm{a}-\mathrm{d}$.

Lectotype. Complete carapace, BM 81.5.23. Length $0.47 \mathrm{~mm}$; height $0.25 \mathrm{~mm}$. Type locality: Stat. I85, Torres Straits, I55 fathoms. ( $\mathrm{II}^{\circ} 35^{\prime} \mathrm{o}^{\prime \prime} \mathrm{S}$, I $44^{\circ} 3^{\prime} \mathrm{o}^{\prime \prime} \mathrm{E}$, August 3I, I874.)

DESCRIPTION. Shape and ornamentation as given by Brady (I880).

REMARKs. Topotypic material: a complete carapace, BM I974.320.

\section{Cythere lauta Brady}

(P1. I4, figs 5-8)

Cythere lauta Brady, $1880: 85$, pl. 21, figs 4 a-d.

Lectotype. Whole carapace, BM 8r.5.24. Length $0.62 \mathrm{~mm}$; height $0.26 \mathrm{~mm}$. Type locality: Stat. I87, off Booby Island, north of Australia. ( $10^{\circ} 36^{\prime} \mathrm{o}^{\prime \prime} \mathrm{S}$, $\mathrm{I} \mathrm{I}^{\circ} 55^{\prime} \mathrm{o}^{\prime \prime} \mathrm{E}$, dredged, $6-8$ fathoms, coral mud, surface temp. $77 \cdot 7^{\circ} \mathrm{F}$, September 9 , I874.)

Description. Shape and ornamentation: see Brady (I880) and Pl. I4, figs 5-8. Eyespots well developed. Internal features not observed.

Remarks. Brady (I880, p. 85) described this species from only one station (Stat. I87) and figured a complete carapace (pl. 2I, figs ra-d). Sediment sample M-242 yielded a left valve and a complete carapace. Topotypic material: a left valve, BM I974.290, and a complete carapace, BM I974.29I.

\section{Cythere lepralioides Brady}

(Pl. I2, figs Io, II)

Cythere lepralioides Brady, 1880 : 94, pl. 19, figs 5a-d.

Lectotype. Right valve of a late instar, BM 80.38.9I. Length $0.75 \mathrm{~mm}$; height $0.47 \mathrm{~mm}$. Type locality: Stat. I42, off Cape of Good Hope, I50 fathoms. $\left(35^{\circ} 04^{\prime} \mathrm{o}^{\prime \prime} \mathrm{S}, 18^{\circ} 37^{\prime} \mathrm{o}^{\prime \prime} \mathrm{E}\right.$, dredged, sand, bottom temp. $47 \cdot 0^{\circ} \mathrm{F}$, surface temp. $65 \cdot 5^{\circ} \mathrm{F}$, December I8, I873.)

Description. Shape and ornamentation as described by Brady (I880). See Pl. I2, fig. Io. Inner lamella: the anterior vestibule is very small but the posterior vestibule is even smaller and narrower. Hinge lophodont. The hinge is not fully developed, but the anterior and posterior elements have a smooth broad tooth, each with a smooth groove. See Pl. I2, fig. II. Central muscle scars: adductor muscle scar consists of four elongated scars vertically arranged.

Remarks. Brady (I88o, p. 94) reported this species from two stations (Simon's Bay, Stat. I40, and off Cape of Good Hope, Stat. I42) and he figured a complete carapace. The lectotype is a late instar of a right valve from Stat. I42. This 
species is common in Simon's Bay sediment sample M-I64. Topotypic material: a right valve, BM I974.3I2.

\section{Cythere lubbockiana Brady}

$$
\text { (Pl. 8, figs } 13, \mathrm{I} 4)
$$

Cythere lubbockiana Brady, I880 : 68, 69, pl. I4, figs 6a-d.

Lectotype. Whole carapace, BM 8I.5.25. Left valve: length $0.8 \mathrm{I} \mathrm{mm}$; height $0.34 \mathrm{~mm}$; right valve : length $0.79 \mathrm{~mm}$; height $0.33 \mathrm{~mm}$. Type locality: Stat. I87, Booby Island, north of Australia, 6-8 fathoms. $\quad\left(\mathrm{I}^{\circ} 36^{\prime} \mathrm{O}^{\prime \prime} \mathrm{S}\right.$, I4 $4 \mathrm{I}^{\circ} 55^{\prime} \mathrm{o}^{\prime \prime} \mathrm{E}$, dredged, coral and sand, surface temp. $77 \cdot 7^{\circ} \mathrm{F}$, September 9, I874.)

Description. Shape and ornamentation as described by Brady (I880). See Pl. 8, fig. I3. Overlap, slight overlap of right valve by the left.

Remarks. Brady (I880, pp. 68, 69) reported this species from only one station and he figured a complete carapace (pl. I4, figs 6a-d). Two specimens, one complete and the other a left valve, were recovered from sediment sample M-242, which represents this station. Topotypic material: a complete carapace, BM I974.32I, and a left valve, BM I974.322.

\section{Cythere mackenziei nom. nov.}

$$
\text { (Pl. 9, figs I-4) }
$$

Cythere pyriformis Brady, I880: 77, 78, pl. I5, figs $3 \mathrm{a}-\mathrm{d}$.

non Cythere amygdaloides pyriformis Cornuel, I846 : I98, fig. II (Lower Cretaceous, France).

Lectotype. Left valve, BM 80.38.ro3. Length I.09 mm; height $0.68 \mathrm{~mm}$. Type locality: Stat. I20, off Pernambuco, Brazil, 675 fathoms. $\quad\left(8^{\circ} 37^{\prime} 0^{\prime \prime S}, 34^{\circ} 28^{\prime} 0^{\prime \prime} \mathrm{W}\right.$, trawled, mud, surface temp. $78 \cdot 0^{\circ} \mathrm{F}$, September 9, I873.)

Description. Shape and ornamentation: see Brady (I880). Inner lamella: anterior vestibule very well developed. Marginal pore canals mostly straight, a few branched and many marginal pore canals present in the anterior and posterior vestibula. Hinge amphidont/heterodont. Normal pores open. Central muscle scars: the central muscle scars consist of four prominent, vertical, closely arranged adductor muscles and one V-shaped frontal scar. See Pl. 9, fig. 2. Eyespot present.

Remarks. Brady (I88o, pp. 77,78 ) reported this species only from Stat. I20 and figured a left valve (pl. 20, figs $3 \mathrm{a}-\mathrm{d}$ ) ; the lectotype designated in this paper is also a left valve. A broken left valve was recovered from sediment sample M-I40. Topotypic material: a broken left valve, BM I974.332.

\section{Cythere moseleyi Brady}

(Pl. 6, figs I-3)

Cythere moseleyi Brady, I880:64, 65, pl. I2, figs 5a-f.

Lectotype. Whole carapace (male), BM 80.38.93. Right valve: length $0.68 \mathrm{~mm}$; height $0.33 \mathrm{~mm}$; left valve : length $0.68 \mathrm{~mm}$; height $0.34 \mathrm{~mm}$. Type 
locality: Stat. 3I6. Stanley Harbour, Falkland Islands, 6 fathoms. $\left(5 \mathrm{I}^{\circ} 32^{\prime} \mathrm{o}^{\prime \prime S}\right.$, $58^{\circ} 06^{\prime} \mathrm{o}^{\prime \prime} \mathrm{W}$, anchor mud, February I, I876.)

DESCRIPTION. Shape and ornamentation as described by Brady (I880). Inner lamella well developed, as observed through the shell. Hinge modified entomodont. Central muscle scars: the adductor scars are vertically arranged.

\section{Cythere murrayana Brady}

(Pl. 9, figs I7-I9)

Cythere murrayana Brady, $1880: 69,70$, pl. 16, figs $4 \mathrm{a}-\mathrm{h}$.

Lectotype. Whole carapace, BM 80.38.94. Right valve: length $0.46 \mathrm{~mm}$; height $0.25 \mathrm{~mm}$; left valve : length $0.47 \mathrm{~mm}$; height $0.25 \mathrm{~mm}$. Type locality: Wellington Harbour, New Zealand. (Trawl-net at trawl, between June 24, and July 8, I874.)

DESCRIPTION. Shape and ornamentation as described by Brady (I880).

\section{Cythere obtusalata Brady}

(Pl. 5, figs IO-I2)

Cythere obtusalata Brady, i880 : 91, pl. I2, figs ra-c.

Lectotype. Right valve, BM 80.38.96. Length $0.64 \mathrm{~mm}$; height $0.34 \mathrm{~mm}$. Type locality: Stat. I62, off East Moncœur Island, Bass Straits, 38-40 fathoms. $\left(39^{\circ} \mathrm{Io}^{\prime} 30^{\prime \prime} \mathrm{S}, 146^{\circ} 37^{\prime} \mathrm{o}^{\prime \prime} \mathrm{E}\right.$, dredged, sand, surface temp. $63 \cdot 2^{\circ} \mathrm{F}$, April 2, I874.)

Description. Shape and ornamentation as described by Brady (I880). See Pl. 5, figs Io and I2. Inner lamella narrow, widest anteriorly; no vestibula present. Marginal pore canals straight, few, moderately spaced. Hinge holamphidont, see P1. 5, fig. II. Central muscle scars: see Pl. 5, fig. I2.

Remarks. Brady (I880, p. 9I) described this species from Stat. I62 and off Admiralty Islands. The lectotype is a right valve from Stat. I62 (Brady, I880, pl. I2, figs Ia-c also figured a right). Two specimens, a right and a left valve, were recovered from sediment sample M-I95 (Stat. I62). Topotypic material: a right valve, BM I974.330, and a left valve, BM I974.33I.

\section{Cythere packardi Brady}

$$
\text { (P1. I2, figs 4-6) }
$$

Cythere packardi Brady, 1880 : 88 , pl. 19, figs 2a-d.

Lectotype. Whole carapace, BM 81.5.26. Left valve: length $0.56 \mathrm{~mm}$; height $0.33 \mathrm{~mm}$; right valve : length $0.54 \mathrm{~mm}$; height $0.3 \mathrm{I} \mathrm{mm}$. Type locality: Stat. I87, Booby Island, north of Australia, 6-8 fathoms. ( $\mathrm{Io}^{\circ} 36^{\prime} \mathrm{o}^{\prime \prime} \mathrm{S}$, $\mathrm{I}_{4} \mathrm{I}^{\circ} 55^{\prime} \mathrm{o}^{\prime \prime} \mathrm{E}$, dredged, coral and sand, surface temp. $77 \cdot 7^{\circ} \mathrm{F}$, September 9, I874.) 
Description. Shape and ornamentation: see Brady (I880), and Pl. I2, figs 4 and 6. Eyespots: a small eyespot is present.

REMARKs. Brady (I880, p. 88) reported this species from only one station (off Booby Island) and he figured a complete carapace (pl. 9, figs 3a-d). A left valve was recovered from sediment sample M-242, which represents this station. Topotypic material: a left valve, BM I974.3II.

\section{Cythere papuensis Brady}

(Pl. I6, figs II-I8; Fig. 7)

Cythere papuensis Brady, 1880 : 95, pl. 25, figs 5a-d.

Lectotype. Left valve, BM 80.38.98. Length $0.78 \mathrm{~mm}$; height $0.48 \mathrm{~mm}$. Type locality: Humboldt Bay, Papua, 37 fathoms, March 24, I875.

Description. Shape and ornamentation as described by Brady (I880). See P1. I6, figs II, I2, I7. Marginal pore canals: the posterior pore canals are straight, some angled, and are mostly obscured except for two canals. Anterior pore canals are moderately numerous, straight and some are at an angle toward the dorsum. (See Fig. 7.) Hinge holamphidont (modified). See Pl. I6, figs I5, I6, I8 and Fig. 7. Normal pores: the open normal pores are numerous, usually one or two per reticulation on the carapace. Central muscle scars: the adductor muscle consists of four scars; the middle dorsal scar resembles a down-facing, partially flattened $L$, the bottom two scars are very close together with the ventral-most scar being slightly anterior. The frontal scar is a somewhat, flattened $V$ whose apex points to the bottom of the adductor muscle. In the dorsal scar field, one scar is visible directly above the gap between the adductor scars and the frontal scar (see Pl. I6, fig. I7 and Fig. 7).

Remarks. Brady (I880, p. 95) described and figured this species from only one station (Humboldt Bay, Papua). A right and a left valve were recovered from sediment sample M-277. Topotypic material: a right valve, BM I974.298, and a left valve, BM I974.299.

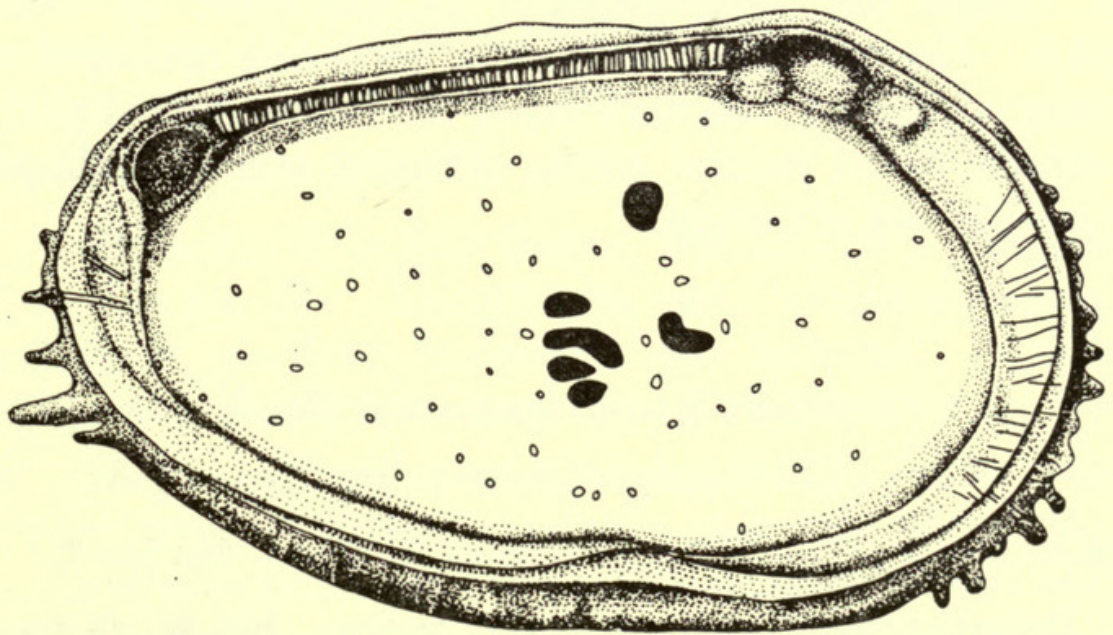

FIG. 7. Cythere papuensis Brady: interior view of lectotype $(\times 97)$. 


\section{Cythere parallelogramma Brady}

(P1. 8, figs $\mathrm{I}_{5}-\mathrm{I} 8$ )

Cythere parallelogramma Brady, $1880: 82,83$, pl. I5, figs ra-e.

Lectotype. Right valve, BM 80.38.99. Length $0.99 \mathrm{~mm}$; height $0.43 \mathrm{~mm}$. Type locality: off Prince Edward's Island, 50-I50 fathoms, December 26, I874, near Stat. I45.

Description. Shape and ornamentation as described by Brady (I880), see Pl. 8, fig. I5. Inner lamella: anterior vestibule narrow. Marginal pore canals straight, evenly spaced and numerous. Hinge holamphidont (see Pl. 8, figs I6 and I8). Central muscle scars: central muscle scar area has a vertical adductor muscle pattern which consists of four scars, the second from the bottom is elongated into a dumb-bell shape and the top scar is divided into two with one V-shaped. The frontal muscle consists of three separate scars forming a $V$ in outline. Three dorsal muscle scars are present (see $\mathrm{Pl}$. 8, fig. I7).

Remarks. This species was reported by Brady (I880, pp. 82, 83) from only one station (off Prince Edward's Island) and he figured a male left valve (pl. I5, figs $\mathrm{Ia}-\mathrm{b}$ ) and a male right valve (pl. I5, figs Ic-e). A right and a left valve were recovered from sediment sample M-I69, which represents this station. Topotypic material: a right valve, BM I974.325, and a left valve, BM I974.326.

\section{Cythere patagoniensis Brady}

(P1. I5, figs 5-8)

Cythere patagoniensis Brady, I880: 93, pl. 23, figs 3a-d.

Lectotype. Whole carapace, BM 8r.5.27. Right valve: length $0.68 \mathrm{~mm}$; height $0.38 \mathrm{~mm}$; left valve: length $0.7 \mathrm{I} \mathrm{mm}$; height $0.38 \mathrm{~mm}$. Type locality: Stat. 308, off Argentina, I 75 fathoms. $\left(50^{\circ} 08^{\prime} 30^{\prime \prime} \mathrm{S}, 74^{\circ} 4 \mathrm{I}^{\prime} \mathrm{o}^{\prime \prime} \mathrm{W}\right.$, trawled, mud, surface temp. $5 \mathrm{I} \cdot 7^{\circ} \mathrm{F}$, January $5, \mathrm{I} 876$.)

Description. Shape and ornamentation as described by Brady (I880), see Pl. I5, figs 5 and 6 . Central muscle scars: four vertically arranged adductor muscle scars, the top being separated, the next being the largest and slightly curved downward over the closely fitted ventral scars. Frontal scar is V-shaped. Hinge and details of inner lamella not observed.

\section{Cythere quadriaculeata Brady}

(Pl. I4, figs I4-I8; Fig. 8)

Cythere quadriaculeata Brady, 1880: 86, pl. 22, figs 2a-d, pl. 25, figs 4a-d.

Lectotype. Disarticulated right and left valves, BM 80.38.50. Right valve: length $0.52 \mathrm{~mm}$; height $0.34 \mathrm{~mm}$; left valve: length $0.53 \mathrm{~mm}$; height $0.34 \mathrm{~mm}$. 


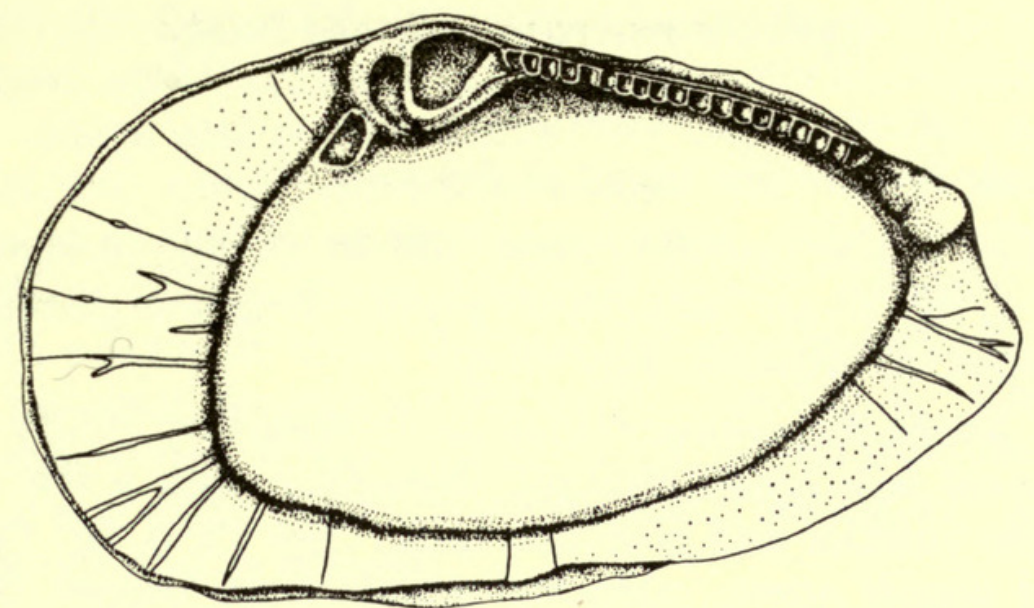

FIG. 8. Cythere quadriculeata Brady : interior (disarticulated) right valve view of lectotype ( $\times$ I 49).

Type locality: Stat. 233b, Inland Sea of Japan, I5 fathoms. (34 ${ }^{\circ} 8^{\prime} \mathrm{o}^{\prime \prime} \mathrm{N}$, $\mathrm{I} 33^{\circ} 35^{\prime} \mathrm{o}^{\prime \prime} \mathrm{E}$, trawled, mud, surface temp. $66 \cdot 3^{\circ} \mathrm{F}$, May $26, \mathrm{I} 875$.)

Description. Shape and ornamentation as described by Brady (I880), see Pl. I4, fig. I4. Marginal pore canals widely spaced, branching canals with a few false and straight canals. Some of the canals have a bulbous area midway along their length, see Fig. 8. Hinge holamphidont. See Pl. I4, figs I6 and I7 and Fig. 8. Overlap: left valve slightly larger than the right.

Remarks. Cythere quadriaculeata Brady is the type species of Spinileberis Hanai, I96I. Brady (I880, p. 86) reported this species from two stations (Stat. 233b and off the reefs at Honolulu) and he figured a complete carapace from Honolulu Stat. (pl. 22, figs 2a-d) and another complete carapace from Stat. 233b (pl. 25, figs 4a-d). The lectotype is from the Inland Sea of Japan (Stat. 233b). A left valve recovered from sediment sample M-298 represents this station. Topotypic material: a left valve, BM I974.329.

\section{Cythere radula Brady}

(Pl. I2, figs 7-9)

Cythere vadula Brady, I880: I02, pl. I9, figs 4a, b.

LECTOTyPe. Left valve of a late instar, BM 81.5.28; designation by Benson (I972, p. 74, pl. I4, figs I6-I8). Length $0.99 \mathrm{~mm}$; height $0.59 \mathrm{~mm}$. Type locality: Stat. Igra, Ki Islands, southern Indonesia, 580 fathoms. $\left(5^{\circ} 26^{\prime} \mathrm{o}^{\prime \prime} \mathrm{S}, \mathrm{I}_{3} 3^{\circ} \mathrm{I} 9^{\prime} \mathrm{o}^{\prime \prime} \mathrm{E}\right.$, mud, surface temp. $8 \mathrm{I} \cdot 5^{\circ} \mathrm{F}$, bottom temp. $40 \cdot 7^{\circ} \mathrm{F}$, September 24 , I874.)

Description. Shape and ornamentation: see Brady (I880), see Pl. I2, fig. 8. Inner lamella: very narrow anterior and the posterior vestibula present. Hinge holamphidont. Central muscle scars: the adductor muscle scars are four in number, vertically arranged, elongate and positioned on the posterior rim of the subcentral tubercle. The V-shaped frontal scar is positioned in the subcentral tubercle. 


\section{Cythere rastromarginata Brady}

(P1. 9, figs 9-I4)

Cythere vastromarginata Brady, $1880: 83$, pl. 16 , figs Ia-d, 2a-d.

LECTOTYPE. Left valve, probably male, BM 80.38.105; designation by Benson (I972, p. II2, pl. I, figs I-4). Length $0.74 \mathrm{~mm}$; height $0.37 \mathrm{~mm}$. Type locality: off reefs at Honolulu, 40 fathoms, July 1875 .

Description. Shape and ornamentation as described by Brady (I880), see Pl. 9, figs 9, Io. Marginal pore canals straight, numerous, with a few branching canals present at both the anterior and posterior ends. See P1. 9, fig. I3. Hinge holamphidont. Central muscle scars: adductor muscle scars consist of four vertically arranged scars, with a V-shaped frontal scar.

REMARKs. Cythere rastromarginata Brady was selected type species of Cletocythereis by Swain, I963. Brady (I880, p. 83) reported this species from three stations (off reefs, Honolulu; Stat. I62 and Stat. I67) and he figured probable male (pl. I6, figs Ia-d) and female carapaces. The lectotype is a left valve, probably male, from reefs off Honolulu. Sediment sample M-324 which represents this station yielded three left valves. Topotypic material: three left valves, BM I974.335-7.

\section{Cythere sabulosa Brady}

(P1. I2, figs I-3; Fig. 9)

Cythere sabulosa Brady, I880: 80, pl. I9, figs Ia-h (fabulosa on pl. I9).

LEстотуре. Disarticulated right and left valves, BM 80.38.I07. Right valve : length $0.68 \mathrm{~mm}$; height $0.40 \mathrm{~mm}$; left valve : length $0.68 \mathrm{~mm}$; height $0.40 \mathrm{~mm}$.

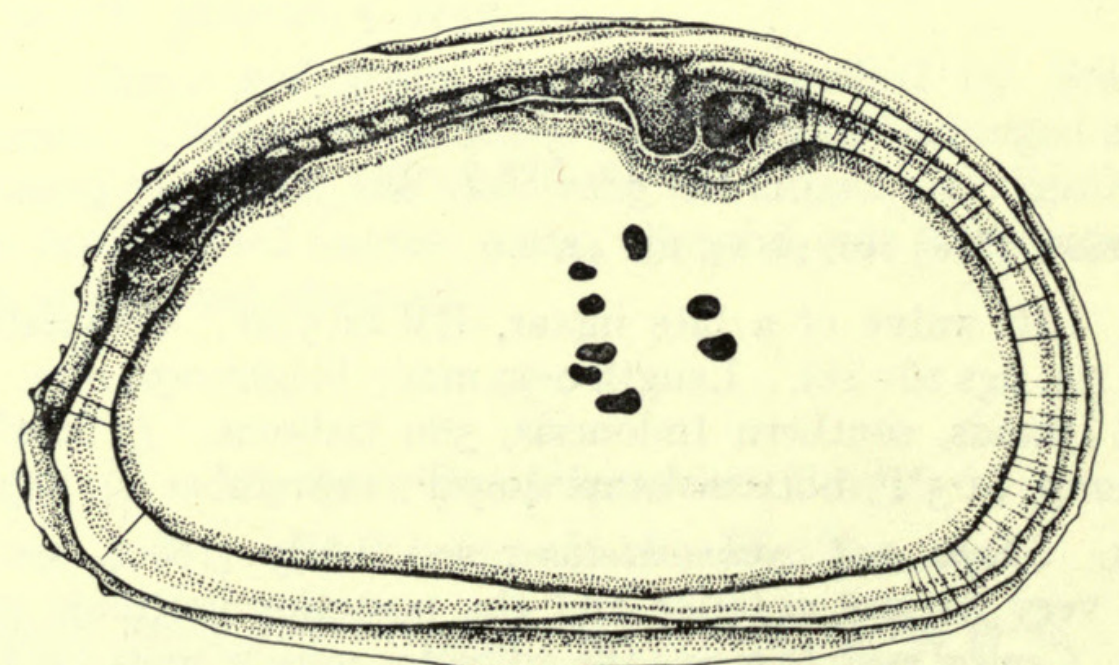

FIG. 9. Cythere sabulosa Brady: interior (disarticulated) left valve view of lectotype ( $\times$ I I5). 
Type locality: Stat. I87, Booby Island, north of Australia, 6-8 fathoms. ( ${ }^{\circ}{ }^{\circ} 36^{\prime} \mathrm{o}^{\prime \prime} \mathrm{S}$, $\mathrm{I}_{4} \mathrm{I}^{\circ} 55^{\prime} \mathrm{O}^{\prime \prime} \mathrm{E}$, dredged, coral and sand, surface temp. $77 \cdot 7^{\circ} \mathrm{F}$, September 9, I874.)

DESCRIPTION. Shape and ornamentation: see Brady (I880), and Pl. I2, figs I and 2. Marginal pore canals: posterior margin has few pores. Anteriorly, the pore canals are most numerous on the ventral edge. Most are straight and moderately spaced. Hinge holamphidont (modified type). Anterior end of the right valve with a tooth pointed in front, flat and step-shaped behind. The median bar is smooth. The posterior element is a flat tooth. See Fig. 9. Central muscle scars: there is a widely spaced row of four adductor scars, second from the bottom split into two, a split frontal scar and a dorsal (?) fulcral scar ; see Fig. 9. Eyespots: a simple, unstalked, definite eyespot is present.

Remarks. Brady (I880, p. 80) reported this species from only one station (Booby Island) and figured a complete female carapace (pl. I9, figs Ia-d) and a complete male carapace (pl. I9, figs Ie-h). A female right and a female left valve were recovered from sediment sample $\mathrm{M}-242$ where this species is common. Topotypic material: right and left valves, BM I974.300-Io.

\title{
Cythere scalaris Brady
}

\author{
(Pl. I4, fig. I3)
}

Cythere scalaris Brady, $1880: 87,88$, pl. 21, figs 8a-c.

LECTOTYPE. Broken right valve (a moult with the centre portion missing), BM 80.38.rog. Length $\mathrm{r} \cdot 00 \mathrm{~mm}$; height $0.53 \mathrm{~mm}$. Type locality: Stat. 305, Ioo fathoms, January I3, I876.

DESCRIPTION. Shape and ornamentation as described by Brady (I880). Inner lamella: the vestibula are nearly non-existent. Marginal pore canals not seen. Hinge of hemimerodont type (modified), the anterior element with a rather reduced broad crenulated tooth with the posterior having a similar, but slightly larger and more conspicuous tooth. The median area is a smooth groove. Central muscle scars: the carapace of the lectotype is broken in the muscle scar region.

Remarks. Brady (I88o, pp. 87, 88) reported this species from two stations (Stat. I85 and 305) and he figured a broken left valve (pl. 2I, fig. 8a) and a broken right valve (pl. $2 \mathrm{I}$, figs $8 \mathrm{~b}, \mathrm{c}$ ). The lectotype is a broken right valve from Stat. 305 . A right and a left valve were recovered from sediment sample M-237, which represents Stat. I85. Topotypic material: a right and a left valve, BM I974.327-8.

\section{Cythere scintillulata Brady}

(Pl. 8, figs 6, 7)

Cythere scintillulata Brady, I880:62, 63, pl. I4, figs 3a-d.

Lectotype. Whole carapace, BM 80.38.rı. Right valve: length o.68 mm; height $0.3 \mathrm{I} \mathrm{mm}$; left valve : length $0.68 \mathrm{~mm}$; height $0.3 \mathrm{I} \mathrm{mm}$. Type locality: 
Stat. 3I3, Straits of Magellan, 55 fathoms. $\left(52^{\circ} 2^{\prime} \mathrm{o}^{\prime \prime} \mathrm{S}, 6^{\circ} \mathrm{o}^{\prime} \mathrm{o}^{\prime \prime} \mathrm{W}\right.$, trawled, sand, bottom temp. $57 \cdot 8^{\circ} \mathrm{F}$, surface temp. $48 \cdot 2^{\circ} \mathrm{F}$, January 20 , I 876 .)

Description. Shape and ornamentation as described by Brady (I880). See Pl. 8, fig. 6. Inner lamella: an anterior vestibule which is moderately wide is present in the paralectotype, BM 80.38.IIo. Marginal pore canals: few straight marginal pore canals present. Central muscle scars and Hinge not observed. Normal pores of open type.

REMARKs. Brady ( 1880 , pp. 62, 63) reported this species from only one station (Straits of Magellan) and he figured a complete carapace (pl. I4, figs 3a-d) of a possible male. Topotypic material: two specimens, one a left valve, BM I974.3I9, and the other a complete carapace of a probable female, BM I974.3I8, were found in sediment sample M-369.

\section{Cythere securifer Brady}

(Pl. 7, figs 8-I5)

Cythere securifer Brady, $1880: 76$, pl. 13, figs $4 a-h$.

Lectotype. Left valve, BM 80.38.II2. Length $0.59 \mathrm{~mm}$; width $0.3 \mathrm{Imm}$. Type locality: near Stat. I45, off Prince Edward's Island, 50-I50 fathoms, December 26, I874.

DEscription. Shape and ornamentation: see Brady (I880) and Pl. 7, figs 8, 9, and I2. The apparent dimorphic posteroventral velate structures are shown on Pl. 7, figs 8-Io. Inner lamella: the anterior vestibule is well developed and larger than the posterior vestibule which is widest on the dorsal side near the posterior hinge. Marginal pore canals straight, widely and regularly spaced. Hinge lophodont. see Pl. 7, figs II, I4, and I5. Central muscle scars: adductor muscle scars consist of four elongate scars arranged vertically but forming a slanted group. A frontal scar is present but the rest are obscured by ornamentation. See Pl. 7, fig. I2.

\section{Cythere (?) serratula Brady}

(P1. 24, figs I5, I6)

Cythere (?) serratula Brady, $1880: 77$, pl. 43, figs $7 \mathrm{a}-\mathrm{d}$.

Lectotype. Right valve, BM 80.38.II3, length $\mathrm{I} .09 \mathrm{~mm}$; height $0.62 \mathrm{~mm}$, Type locality: Stat. 24, off Culebra Island, West Indies, 390 fathoms. ( $18^{\circ} 38^{\prime} 30^{\prime \prime} \mathrm{N}$. $65^{\circ} 05^{\prime} 30^{\prime \prime} \mathrm{W}$, dredged, coral mud, surface temp. $76 \cdot 0^{\circ} \mathrm{F}$, March $25, \mathrm{I} 873$. )

Description. Shape and ornamentation as described by Brady (I880), see Pl. 24, fig. I5. Hinge: undifferentiated type. Selvage forming valve edge. See Pl. 24, fig. I6. Central muscle scars: two curved parallel rows (Cytherellid type) with four and five scars respectively. 
Remarks. Brady (I880, p. 77) reported this species from Stat. 24, Stat. 85, and Stat. 335. The lectotype, a right valve, is from Stat. 24. Topotypic material: a left valve, BM I974.387, was picked from sediment sample M-44 (Stat. 24). Two small specimens recovered from sediment sample M-Io6 (Stat. 85, off Canaries, II25 fathoms) may belong to this species.

\section{Cythere scabrocuneata Brady}

(P1. 26, figs 6 and 8)

Cythere scabrocuneata Brady, 1880 : 103, pl. I7, figs 5a-f; pl. 23, figs 2a-c.

non Trachyleberis scabrocuneata (Brady), Brady, I898:444, pl. 47, figs I-7, I8-25.

non Trachyleberis scabrocuneata (Brady), Hornibrook, 1952:32-33, pl. 3, figs 38, 39, 48.

LECTOTYPE. BM I952.I2.IO, I, 2 (specimen lost); designation by Harding \& Sylvester Bradley (I953 p. I2). Type locality: Stat. 233b, Inland Sea, Japan, I5 fathoms $\left(34^{\circ} 20^{\prime} \mathrm{o}^{\prime \prime} \mathrm{N}, \mathrm{I} 33^{\circ} 35^{\prime} \mathrm{o}^{\prime \prime} \mathrm{E}\right)$.

Description. Shape and ornamentation: see Pl. 26, figs 6 and 8. Hinge holamphidont. Normal pores simple.

Remarks. Topotypic material: two specimens, a right and a left valve, BM I974.324, were found in sediment material from Stat. 233b. The left valve is figured (Pl. 26, figs 6 and 8).

\section{Cythere squalidentata Brady}

(P1. I6, figs 3-5)

Cythere squalidentata Brady, I880 : I10, pl. 23, figs 8a-d (squabidentata on pl. 23).

LEстотуре. Whole carapace (early instar), BM 8I.5.29; designated by Benson (I97I p. 8, pl. I, fig. 9; nomen dubium). Right valve: length $0.43 \mathrm{~mm}$; height $0.26 \mathrm{~mm}$ : left valve : length $0.43 \mathrm{~mm}$; height $0.25 \mathrm{~mm}$. Type locality: Stat. 323 , off the coast of Uruguay, I 900 fathoms. $\left(35^{\circ} 39^{\prime} \mathrm{o}^{\prime \prime} \mathrm{S}, 50^{\circ} 47^{\prime} \mathrm{o}^{\prime \prime} \mathrm{W}\right.$, trawled, grey ooze, bottom temp. $33 \cdot \mathrm{I}^{\circ} \mathrm{F}$, surface temp. $73 \cdot 5^{\circ} \mathrm{F}$, February 28 , I876.)

Description. Shape and ornamentation as described by Brady (I880), see Pl. I6, figs 3 and 4 . Overlap: none.

\section{Cythere stolonifera Brady}

(Pl. I4, fig. 4)

Cythere stolonifera Brady, I880: 89, pl. 2I, figs 3a-d.

Lectotype. Articulated carapace with the anterior end damaged, BM 80.38.II5. Right valve : length $0.74 \mathrm{~mm}$; height $0.37 \mathrm{~mm}$. Type locality: Stat. I40, Simon's Bay, South Africa, I5-20 fathoms, October 1873.

Description. Shape and ornamentation: see Brady (I880) and Pl. I4, fig. 4. 


\section{Cythere subrufa Brady}

(Pl. I3, figs I-9)

Cythere subrufa Brady, 1880 : 81, pl. 20, figs 3a-f.

Lectotype. Disarticulated right and left valves, BM 80.38.II7. Right valve: length $0.78 \mathrm{~mm}$; height $0.38 \mathrm{~mm}$; left valve: length $0.8 \mathrm{I} \mathrm{mm}$; height $0.40 \mathrm{~mm}$. Type locality: Stat. I49, Balfour Bay, Kerguelen, 20-50 fathoms, January I874.

Description. Shape and ornamentation: see Brady (I880) and Pl. I3, figs I, 4 and 5. Marginal pore canals: posterior canals, few mostly straight. Anteriorly the canals are most numerous on the ventral edge of the vestibula. They are all straight with a few false canals present, more frequently on the ventral edge. Hinge hemiamphidont, see P1. I3, figs 7 and 8. Normal pores of open type. Central muscle scars: see Pl. I3, fig. 9. Eyespots present but not greatly developed.

Remarks. Brady (I880, p. 8I) reported this species from two stations (Balfour Bay, Kerguelen Island, Stat. I49, and off Prince Edward's Island) and he figured a male (pl. 20, figs $3 \mathrm{a}-\mathrm{d}$ ) and a female (pl. 20, figs 3e, f). Topotypic material: a right, BM I974.347, and a left valve, BM I974.348, were recovered from sediment sample M-I69 which represents Prince Edward's Island, 50-I50 fathoms.

\section{Cythere suhmi Brady}

(Pl. I7, figs 7-I2; Fig. Io)

Cythere suhmi Brady, 1880: 106, 107, pl. 26, figs 3a-h.

Lectotype. Disarticulated right and left valves, BM 80.30.II9. Right valve : length I.2I mm; height $0.68 \mathrm{~mm}$; left valve : length I.I5 mm; height $0.68 \mathrm{~mm}$. Type locality: Stat. 24I, northwest Pacific, 2300 fathoms. $\left(35^{\circ} 4 \mathrm{I}^{\prime} \mathrm{o}^{\prime \prime} \mathrm{N}, \mathrm{I} 57^{\circ} 42^{\prime} \mathrm{o}^{\prime \prime} \mathrm{E}\right.$, trawled, red clay, bottom temp. $35^{\circ} \mathrm{I}^{\circ} \mathrm{F}$, surface temp. $69 \cdot 2^{\circ} \mathrm{F}$, June $23, \mathrm{I} 875$.)

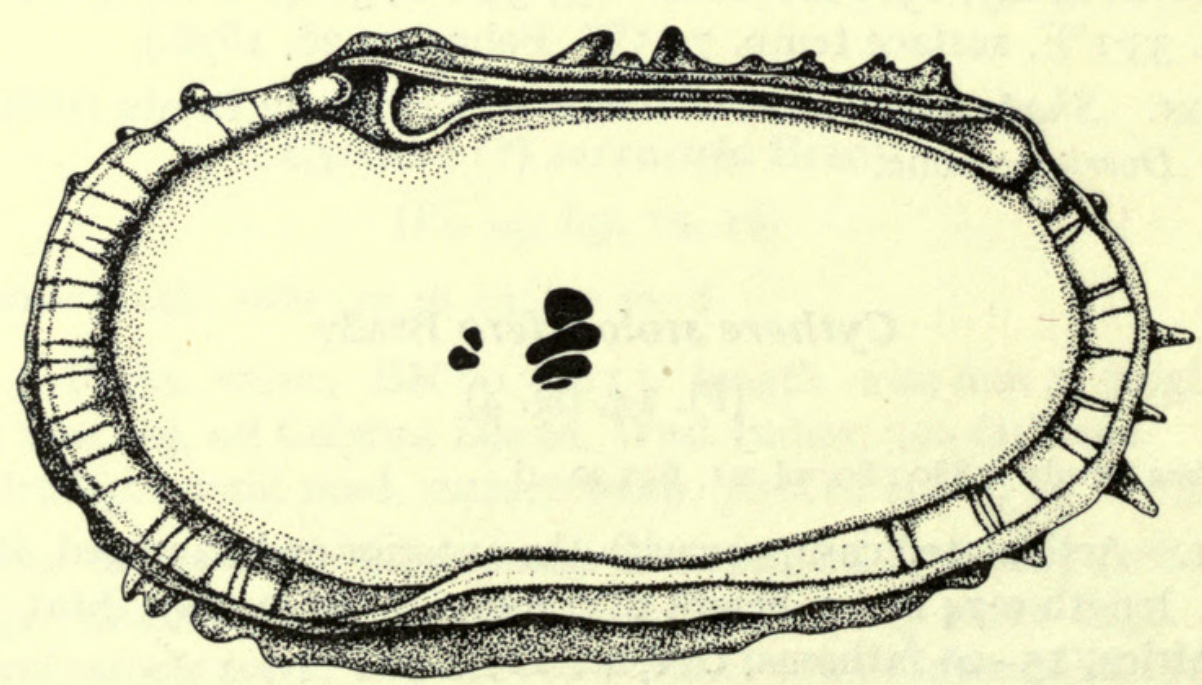

FIG. Io. Cythere suhmi Brady: interior view of lectotype $(\times 72)$. 
Description. Shape and ornamentation as described by Brady (I880). See Pl. I7, figs 7, 8 and Io. Inner lamella: narrow anterior and posterior vestibula developed. Marginal pore canals more numerous at the anterior end; mostly straight with a few false canals. See Fig. Io. Hinge holamphidont. See Pl. I7, figs 9 and Io and Fig. Io. Central muscle scars: adductor muscle scars four in number and arranged vertically. The two central scars are the larger and somewhat elongate. The dorsal scar is circular but faint, while the ventral scar is small and nearly fused with the one above. The frontal scar has two very close scars, one circular on the ventral side and one elongate on the more dorsal side ; see Fig. Io.

Remarks. Brady (I880, pp. I06, I07) reported this species from two stations (Prince Edward's Island and Stat. 24I). He figured a female carapace (pl. 24, figs $3 \mathrm{a}-\mathrm{d}$ ) and a complete male (pl. 24, figs $3 \mathrm{e}-\mathrm{h}$ ). Topotypic material: a left valve, BM I974.289, was recovered from sediment sample M-I69 which represents Prince Edward's Island, 50-I50 fathoms.

\section{Cythere sulcatoperforata Brady}

(Pl. I7, figs I-2; Fig. II)

Cythere sulcatoperforata Brady, I880 : 99, pl. 26, figs Ia-d.

Lectotype. Left valve, BM 8I.5.30. Length I.33 mm; height o.8I mm. Type locality: Stat. 300, off Juan Fernandez Islands, west of Chile, I375 fathoms. $\left(33^{\circ} 42^{\prime} \mathrm{o}^{\prime \prime} \mathrm{S}, 78^{\circ} \mathrm{I} 8^{\prime} \mathrm{o}^{\prime \prime} \mathrm{W}\right.$, Globigerina ooze, trawled, bottom temp. $355^{\circ} \mathrm{F}$, surface temp. $62 \cdot 5^{\circ} \mathrm{F}$, December I7, I875.)

Description. Shape and ornamentation as described by Brady (I880). See Pl. I7, fig. I. Marginal pore canals: the evidence of the canals is obscured and their width is very thin, straight and not bifurcated; see Fig. II. Hinge: hemimerodont

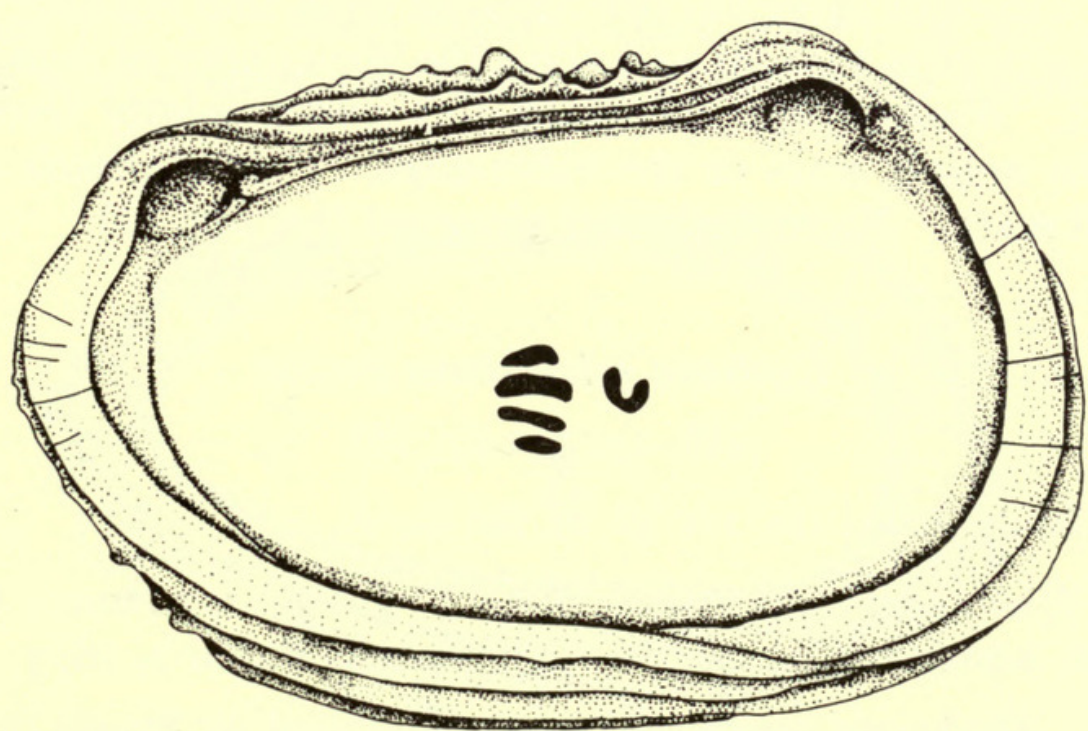

FIG. II. Cythere sulcatoperforata Brady: interior view of lectotype $(\times 62)$. 
type : the left valve hinge consists of a broad anterior socket, a non-crenulate median bar, with a slight point two-thirds of the way back and a broad posterior socket, see Pl. I7, fig. 2, and Fig. II. Central muscle scars: four oval adductor scars with a U-shaped frontal scar, see Pl. I7, fig. 2 and Fig. II.

\section{Cythere torresi Brady}

(P1. I2, figs I2, I3; Fig. I2)

Cythere torresi Brady, 1880:67, 68, pl. 19, figs 8a-c (torresii on plate 19).

Lectotype. Right valve, BM 8r.5.3r. Length $0.34 \mathrm{~mm}$; height $0.22 \mathrm{~mm}$. Type locality: Stat. I85, Torres Straits, I55 fathoms. ( $\mathrm{II}^{\circ} 38^{\prime} \mathrm{I} 5^{\prime \prime} \mathrm{S}$, $\mathrm{I}_{4} 3^{\circ} 59^{\prime} 38^{\prime \prime} \mathrm{E}$, dredged, sand and shells, surface temp. $77^{\circ} 0^{\circ} \mathrm{F}$, August 3I, I874.)

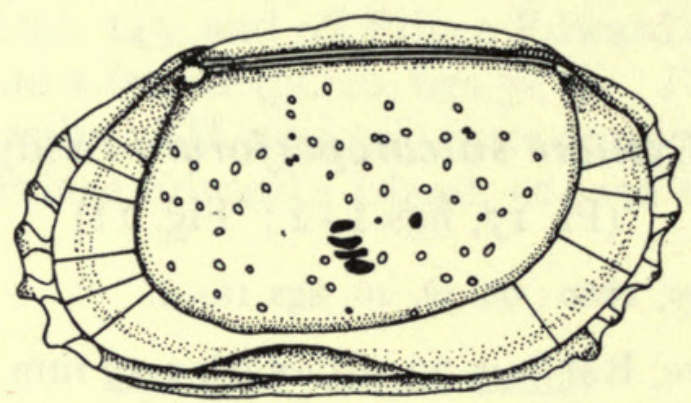

FIG. I2. Cythere torresi Brady: interior view of lectotype ( $\left.\mathrm{I}_{5} \mathrm{O}\right)$.

Description. Shape and ornamentation as described by Brady (I880), see Pl. I2 figs I2 and I3. Inner lamella: line of concrescence coincides with inner margin. Marginal pore canals few, widely spaced, mostly straight, one branched. There appears to be a number which are false but the determination is difficult because of the opaqueness of the inner lamella, see Fig. I2. Hinge between lophodont and antimerodont. The right valve has two terminal teeth that are very thin and appear crenulate. The groove is straight and gives the appearance of being slightly crenulate (see Fig. I2). Normal pores numerous and open; mostly terminally situated and not near the muscle scars or the valve edge. Central muscle scars: four prominent flattened scars. No frontal scars observed (see Fig. I2).

\section{Cythere tricristata Brady}

(P1. I5, figs I7, I8)

Cythere tricristata Brady, I880: IIO, III, pl. 23, figs 6a-d.

Holotype. Whole carapace, BM 80.38.r2r. Length $0.78 \mathrm{~mm}$; height $0.37 \mathrm{~mm}$. Type locality: off Admiralty Island, I6-25 fathoms, March 2, I875.

Description. Shape and ornamentation as described by Brady (I880), see Pl. I5, figs I7 and I8. Hinge holamphidont. 
Remarks. Topotypic material: a left valve, BM I974.340, and two right valves, BM I974.339 \& 34I.

\section{Cythere tetrica Brady}

(Pl. 27, figs 4-6)

Cythere tetrica Brady, 1880: 104, pl. 23, figs 5a-d.

Lectotype. Complete carapace, BM 80.38 (lost during photography). Length $0.54 \mathrm{~mm}$; height $0.27 \mathrm{~mm}$. Type locality: Stat. I87, off Booby Island, lat. $10^{\circ} 36^{\prime} \mathrm{o}^{\prime \prime} \mathrm{S}$, long. $\mathrm{I} 4 \mathrm{I}^{\circ} 44^{\prime} \mathrm{O}^{\prime \prime} \mathrm{E}, 6-8$ fathoms.

Description. Shape and ornamentation as given by Brady (I880), see Pl. 27, figs $4-6$.

Remarks. The lectotype was lost during photography by R. H. Benson. Topotypic material: one complete carapace was recovered from sediment sample M-242, which represents Stat. I87 and is figured here (Pl. 27, figs 4-6). This specimen (BM I974.338), a complete carapace, measures : length $0.64 \mathrm{~mm}$; height $0.32 \mathrm{~mm}$.

\section{Cythere velivola Brady}

(Pl. I5, figs 9-I6; Fig. I3)

Cythere velivola Brady, I880 : III, pl. 23, figs 4a-c.

LEстотуре. Left valve (moult), BM 80.38.I22. Length 0.7I mm; height $0.37 \mathrm{~mm}$. Type locality: Stat. I89, Arafura Sea, 8 fathoms. $\left(9^{\circ} 36^{\prime} \mathrm{o}^{\prime \prime} \mathrm{S}, \mathrm{I} 37^{\circ} 50^{\prime} \mathrm{o}^{\prime \prime} \mathrm{E}\right.$, trawled, mud, surface temp. $79^{\circ} 0^{\circ} \mathrm{F}$, September II, I874.)

Description. Shape and ornamentation as described by Brady (I880), see Pl. I5, figs 9, I5 and I6. Inner lamella: extremely narrow posterior and anterior vestibula, almost non-existent (Pl. I5, fig. I2). Marginal pore canals straight to slightly curved, evenly spaced, bifurcating (one trifurcating) with several false canals. See P1. I5, fig. I2, and Fig. I3. Hinge holamphidont, see Pl. I5, figs I3 and I4, and Fig. 13. Normal pores present over most of the surface and appear to be of sieve

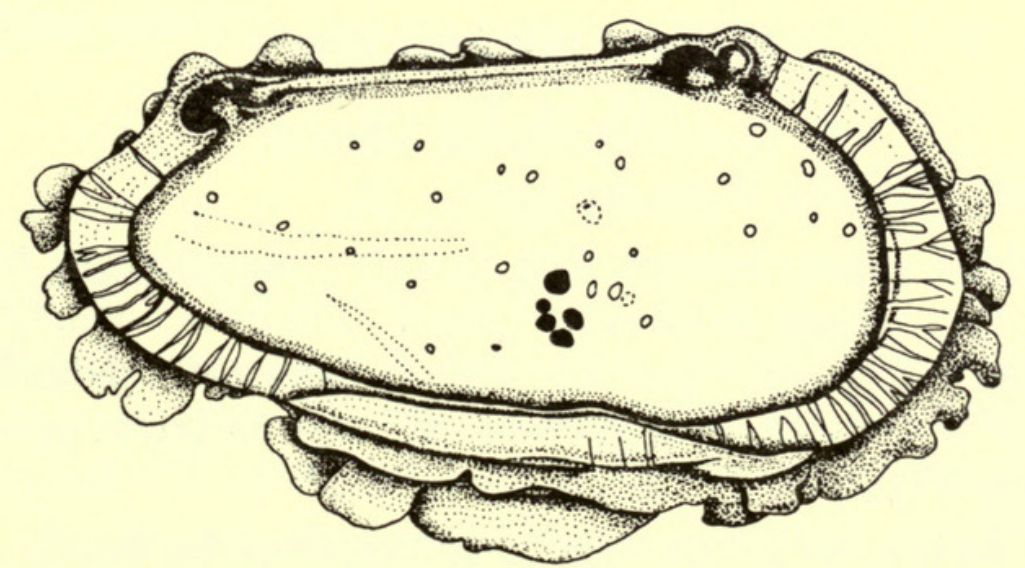

FIG. I3. Cythere velivola Brady: interior view of lectotype $(\times 97)$. 
type. Central muscle scars: adductor muscle scars a vertical row of four, the third scar from the dorsal side is divided into two; frontal scar is made up of three scars in a horizontal line. A dorsal muscle scar is present above the adductor scars, see Fig. I3.

\section{Cythere vellicata Brady}

(Pl. 5, figs $\mathrm{I}_{3}-\mathrm{I} 5$; Fig. I4)

Cythere vellicata Brady, 1880:64, pl. I2, figs 2a-d.

Lectotype. Disarticulated left and right valves, BM 8I.5.32 (separated after photography). Length $0.50 \mathrm{~mm}$; width $0.19 \mathrm{~mm}$. Type locality: Port Jackson, depth 2-Io fathoms, April 20, I874.

Description. Shape and ornamentation as described by Brady (I880), see Pl. 5, fig. I3. Inner lamella: anterior vestibule irregular in outline, posterior vestibule narrow (see Fig. I4). Marginal pore canals branching, anterior and posterior canals arising from very broad bases at the inner edge of the vestibule. Hinge: see Fig. I4. Normal pores clustered in the anterior half of the carapace. Central muscle scars: adductor muscle scar has three close, vertically stacked scars with a large kidneyshaped frontal scar.

Remarks. Topotypic material: a complete carapace, BM I974.365.

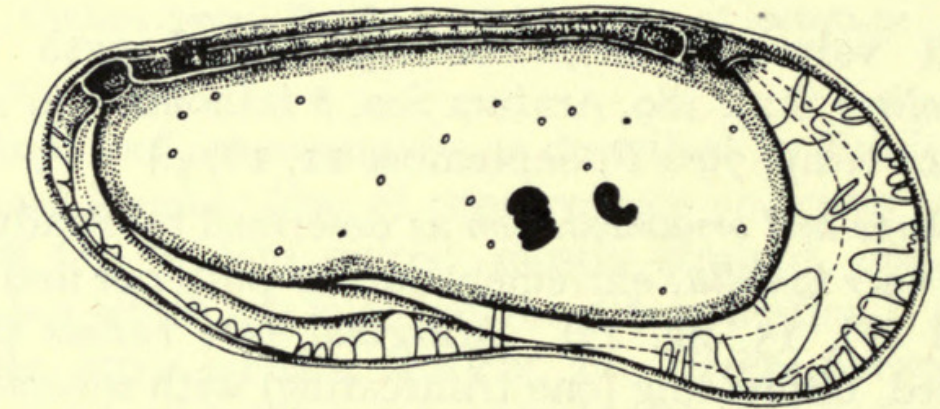

FIG. I4. Cythere vellicata Brady: interior (disarticulated) left valve view of lectotype $\left(\times I_{42}\right)$.

\section{Cythere viminea Brady}

(Pl. II, fig. I5)

Cythere viminea Brady, $1880: 94$, pl. 18 , figs $3 a-c$.

Holotype. Right valve, broken, BM 8I.5.33; designation by Benson (I972, p. 50, pl. II, fig. I5; nomen dubium.) Length $0.8 \mathrm{I} \mathrm{mm}$; height $0.43 \mathrm{~mm}$. Type locality: Stat. I46, deep-sea, east of Prince Edward's Island, I375 fathoms. $\left(46^{\circ} 46^{\prime} \mathrm{o}^{\prime \prime} \mathrm{S}, 45^{\circ} 3 \mathrm{I}^{\prime} \mathrm{o}\right.$ " E, trawled, Globigerina ooze, bottom temp. $35^{\circ} 6^{\circ} \mathrm{F}$, surface temp. $43^{\circ} \mathrm{F}$, December 29, I873.)

Description. Shape and ornamentation as described by Brady (I880). Eyespots well developed. 


\section{Cythere wyvillethomsoni Brady}

(Pl. I3, figs I0-I8; Pl. I4, figs I-3)

Cythere wyvillethomsoni Brady, $1880: 82$, pl. 20, figs $4 \mathrm{a}-\mathrm{f}$.

Lectotype. Disarticulated left and right valves, BM 80.38.r23. Left valve : length $0.83 \mathrm{~mm}$; height $0.38 \mathrm{~mm}$; right valve : length $0.83 \mathrm{~mm}$; height $0.38 \mathrm{~mm}$. Type locality: Christmas Harbour, Kerguelen Island, 20-50 fathoms (on slide); January 29, I874. (Stat. I49 ; depth I20 fathoms on p. I7.)

Description. Shape and ornamentation as described by Brady (I880). See Pl. I3, figs Io and II. Inner lamella: both the anterior and the posterior vestibula are well developed with the anterior vestibule slightly larger. Marginal pore canals numerous on antero-ventral corner reducing in number towards dorsal corner. Mostly straight, a few branched and a few false. Posterior canals mostly straight and few in number, see Pl. I3, figs I2 and I5. Hinge holamphidont. Normal pores of open type. Central muscle scars: muscle scar pattern present not easily discerned. Eyespots present, but not well developed. Second antenna: see Pl. I3, fig. I8. Obtained from the lectotype. Penis: see Pl. I3, fig. I8. Obtained from the lectotype.

Remarks. Brady (I880, p. 82) reported this species from Stat. I49, Balfour Bay, Stat. I50, I5I and questionably from Stat. I85. He figured a female carapace (pl. 20, figs $4 \mathrm{a}-\mathrm{d}$ ) and a male (pl. 20, figs 4e, f). Topotypic material: four specimens, BM I974.349-52, of this species were recovered from sediment sample M-I85 (Stat. I5I).

\section{Genus KRITHE \\ Krithe hyalina Brady \\ (Pl. I8, figs I, 2)}

Krithe hyalina Brady, I880: II5, pl. 27, figs 3a-d.

Lectotype. Whole carapace, BM 8I.5.34. Length $0.59 \mathrm{~mm}$; height $0.3 \mathrm{I} \mathrm{mm}$. Type locality: Stat. 233b, Inland Sea, Japan, I5 fathoms. $\left(34^{\circ} \mathrm{I} 8^{\prime} \mathrm{o}^{\prime \prime} \mathrm{N}, \mathrm{I} 33^{\circ} 35^{\prime} \mathrm{o}^{\prime \prime} \mathrm{E}\right.$, trawled, mud, surface temp. $66 \cdot 3{ }^{\circ} \mathrm{F}$, May 26 , I875.)

Description. Shape and ornamentation as described by Brady (I880) and see P1. I8, fig. I. Hinge adont.

\section{Krithe producta Brady \\ (P1. I7, figs I6-I8)}

Krithe producta Brady, I880: II4, II 5, pl. 27, figs Ia-j.

Lectotype. Whole carapace, BM 80.38.127. Length $0.84 \mathrm{~mm}$; height $0.47 \mathrm{~mm}$. Type locality: Stat. I46, I 375 fathoms. $\left(46^{\circ} 46^{\prime} \mathrm{o}^{\prime \prime} \mathrm{S}, 45^{\circ} 3 \mathrm{I}^{\prime} \mathrm{o}^{\prime \prime} \mathrm{E}\right.$, trawled, Globigerina ooze, bottom temp. $35^{\circ} 6^{\circ} \mathrm{F}$, surface temp. $43^{\circ} 0^{\circ} \mathrm{F}$, December 29 , I873.)

Description. Shape and ornamentation as described by Brady (I880). See Pl. I7, fig. I8. Hinge adont. Central muscle scars: see Pl. I7, figs I6 and I7. 
Remarks. Brady (I880, pp. II4, II5) lists this species from seventeen stations ranging in depth from 50 to 1675 fathoms and considered it to be cosmopolitan. The lectotype is from Stat. I46, depth 1375 fathoms. Krithe producta is common in sediment sample M-I69 (off Prince Edward's Island, 50-I50 fathoms) and as a species should be split into several subspecies. Topotypic material: two left valves, BM I974.353 \& 355, and a right valve, BM I974.354.

\section{Krithe tumida Brady}

(Pl. I8, figs 3-5)

Krithe tumida Brady, I880: I15, I16, pl. 27, figs 4a-d.

LECTOTYPE. Whole carapace, BM 81.5.36 (valves separated after photography). Length $0.62 \mathrm{~mm}$; height $0.37 \mathrm{~mm}$. Typelocality: Stat. 323 . $\left(35^{\circ} 39^{\prime} \mathrm{o}^{\prime \prime} \mathrm{S}, 50^{\circ} 47^{\prime} \mathrm{o}^{\prime \prime} \mathrm{W}\right.$, trawled, grey ooze, I900 fathoms, bottom temp. $33^{\circ} \mathrm{I}^{\circ} \mathrm{F}$, surface temp. $73 \cdot 5^{\circ} \mathrm{F}$, February 28, 1876.)

Description. Shape and ornamentation as described by Brady (I800). See Pl. I8, fig. 3. Hinge adont.

Remarks. Brady (I88o, pp. II5, II6) reported this species from Stat. 323 although he also lists (p. I3) Krithe tumida from Stat. $64\left(35^{\circ} 35^{\prime} \mathrm{o}^{\prime \prime} \mathrm{N}, 50^{\circ} 27^{\prime} \mathrm{o}^{\prime \prime} \mathrm{W}, 275^{\circ}\right.$ fathoms, grey ooze, June 20, I873.) A left valve was recovered from sediment sample M-86 (Stat. 64) and is registered BM r974.356.

\section{Genus LOXOCONCHA}

\section{Loxoconcha africana Brady}

(Pl. I8, figs I3, I4)

Loxoconcha africana Brady, 1880 : I1 8, pl. 28, figs 3a-d.

LECTOTYPE. Disarticulated right and left valves, portion of anteroventral margin missing, BM 80.28.130. Right valve : length $0.59 \mathrm{~mm}$; height $0.40 \mathrm{~mm}$; left valve : length $0.59 \mathrm{~mm}$; height $0.37 \mathrm{~mm}$. Type locality: St Vincent, Cape Verde, I070-II50 fathoms, April 26, I876.

DESCRIPTION. Shape and ornamentation as given by Brady (I880), except for absence of papillae on lectotype. See P1. I8, fig. I3. Inner lamella narrow anteriorly and posteriorly with anterior and posteroventral vestibula. Marginal pore canals: about I7 simple canals. Hinge: aberrant amphidont type. In the right valve there is an anterior crescent-shaped socket within which there is a small tooth. The median element is crenulated. The posterior element consists of a divided tooth with a socket between. Normal pores large, scattered, round and elongate sieve-type. Central muscle scars: row of four adductor scars, single V-shaped frontal scar. Eyespot present. 


\section{Loxoconcha anomala Brady}

(P1. I8, figs 6-9)

Loxoconcha anomala Brady, 1880 : 123, pl. 27, figs 5a-d.

Lectotype. Disarticulated right and left valves, BM 80.38.I32. Right valve : length $0.65 \mathrm{~mm}$; height $0.43 \mathrm{~mm}$; left valve : length $0.62 \mathrm{~mm}$; height $0.43 \mathrm{~mm}$. Type locality: from reefs at Honolulu, 40 fathoms, July 1875 .

Description. Shape and ornamentation as given by Brady (I880). See Pl. I8, figs 6-9. Inner lamella wide throughout, line of concrescence and inner margin coincide; no vestibula. Marginal pore canals about 22 branching, mostly bifurcate, a few trifurcate and single. Hinge adont. Central muscle scars: adductors consist of a vertical row of four elongate scars and a frontal scar. Eyespot present.

Remarks. Topotypic material: one specimen, a left valve (lost) and a right valve, BM I974.360, was found in sediment sample M-324 (reefs at Honolulu).

\section{Loxoconcha australis Brady \\ (Pl. I8, figs I7, I8; Pl. I9, figs I-4)}

Loxoconcha australis Brady, I880: II9, I20, pl. 28, figs 5a-f ; pl. 29, figs.3a-d.

Lectotype. Left valve, BM 80.38.133. Length $0.78 \mathrm{~mm}$; height $0.37 \mathrm{~mm}$. Type locality: Port Jackson, Australia, 2-Io fathoms, April 20, I874.

Description. Shape and ornamentation as given by Brady (I880). See Pl. I9, figs 2 and 4. Inner lamella: see Pl. I8, fig. I8; Pl. I9, figs 2 and 3, the anterior vestibule is present but posteroventral vestibule absent. Inner lamella of about uniform width, selvage strong. Marginal pore canals: nine anterior and six ventral and posterior simple, straight canals. See Pl. I9, fig. 3. Hinge: see Pl. I9, fig. 3, aberrant amphidont, anteriorly a strong tooth followed by a crenulate bar. Posteriorly a large crescent-shaped socket with weak tooth. Normal pores scattered, large, rounded, sieve-type pore canals. Central muscle scars: vertical rows of four adductors, frontal scar kidney-shaped. Eyespot present and located low on carapace.

Remarks. Sediment sample M-242 (Stat. I87, off Booby Island, lat. $10^{\circ} 36^{\prime} \mathrm{o}^{\prime \prime} \mathrm{S}$, long. $\mathrm{I} 4 \mathrm{I}^{\circ} 5^{\prime} \mathrm{O}^{\prime \prime} \mathrm{E}, 6-8$ fathoms) yielded six complete carapaces, one of which was disarticulated. Topotypic material: disarticulated carapace, BM I974.363.

\section{Loxoconcha honoluliensis Brady}

(P1. I9, figs 5, 6)

Loxoconcha honoluliensis Brady, I880: II7, II8, pl. 28, figs 6a-f.

Lectotype. Disarticulated right and left valves, BM 80.38.r36. Right valve : length $0.62 \mathrm{~mm}$; height $0.43 \mathrm{~mm}$; left valve : length $0.59 \mathrm{~mm}$; height $0.43 \mathrm{~mm}$. Type locality: reefs off Honolulu, 40 fathoms, July I875. 
Description. Shape and ornamentation as given by Brady (I880). See Pl. I8, figs 5 and 6. Lectotype and topotype pitted. Opaque areas present over most of the valves. Inner lamella widest anteriorly and posteroventrally. Line of concrescence irregular and indistinct. Marginal pore canals: most of the branching type terminating in two, mostly three branches near the outer margin. Less than 30 canals somewhat evenly spaced throughout, a few false canals at the anterior end. Hinge adont. Right valve with a medium groove between two bars. Left valve with a median bar. Normal pores: sieve type, large and numerous. Central muscle scars: a vertical row of four elongate scars with the dorsal-most the longest and concave dorsally. Frontal scar V-shaped. Eyespots low and somewhat indistinct.

Remarks. Type locality for the lectotype, sediment sample M-324, yielded only two specimens, a right and a left valve. Loxoconcha honoluliensis was selected as type species of Loxoconchella by Triebel, I954. Topotypic material: a right valve, BM I974.36I ; a left valve lost.

\section{Loxoconcha pumicosa Brady}

(Pl. I8, figs IO-I2)

Loxoconcha pumicosa Brady, I880: I18, II9, pl. 28, figs 2a-d.

Lectotype. Whole carapace, BM 8I.5.37 (left valve lost after photography). Length $0.50 \mathrm{~mm}$; height $0.34 \mathrm{~mm}$. Type locality: Nares' Harbour, Admiralty Islands, I6 fathoms, March 2, I875.

Description. Shape and ornamentation as described by Brady (I880). See Pl. I8, figs Io and II. Inner lamella widest anteriorly, anterior and posteroventral vestibula present. Selvage strong. Marginal pore canals simple and straight. Hinge : aberrant amphidont hinge. Anteriorly, a crescent-shaped socket with a weak tooth followed by a crenulate bar. Posteriorly, a large crescent-shaped and incompletely divided tooth with a small socket inside the crescent. Eyespot present but inconspicuous.

Remarks. Two complete carapaces of this species were recovered from sediment sample M-279 (Nares' Harbour). Brady (I880, pp. II8, II9) also reported this species from off Booby Island (Stat. I87). Topotypic material: a complete carapace, BM I974.359.

\section{Loxoconcha subrhomboidea Brady}

(P1. I8, figs I5, I6)

Loxoconcha subrhomboidea Brady, I880 : I21, pl. 28, figs 4a-d.

Lectotype. Whole carapace, Hancock Museum (left valve missing after photography). Length $0.37 \mathrm{~mm}$; height about $0.24 \mathrm{~mm}$. Type locality: Stat. I40, Simon's Bay, South Africa, I5-20 fathoms, October, I873.

Description. Shape as given by Brady (I880) except that the posterior is more angular than rounded and the caudal process is present but weak (see Pl. I8, fig. I5). 
Ornamentation as given by Brady (I880) plus a heavy ventral ridge and deep furrow (see Pl. I8, fig. I5). Inner lamella: anterior and posteroventral vestibula present. Well-developed posteroventral flange. Marginal pore canals simple and straight. Hinge: median element smooth. Posterior element comprises a large crescentic tooth which is incompletely divided, and a small socket inside the crescent. Normal pores few, large rounded sieve-type pores.

Remarks. Topotypic material: a left valve, BM I974.362, was recovered from sediment sample M-I64 (Stat. I40, Simon's Bay), this is the only locality where Brady (I880, p. I2I) found this species.

\section{Genus XESTOLEBERIS}

Xestoleberis africana Brady

(Pl. I9, figs I5, I6)

Xestoleberis africana Brady, I880 : 126 , pl. 30, figs $4 \mathrm{a}-\mathrm{c}$.

Lectotype. Disarticulated right and left valves. Portion of anteroventral region missing on left valve, BM 8I.5.40 (valves separated after photography). Right valve: length $0.40 \mathrm{~mm}$; height $0.31 \mathrm{~mm}$; left valve: length $0.40 \mathrm{~mm}$; height $0.28 \mathrm{~mm}$. Type locality: Stat. I40, Simon's Bay, South Africa, I5-20 fathoms, October 1873 .

DESCRIPTION. Shape and ornamentation as given by Brady (I880) except for absence of papillae. Inner lamella widest anteriorly narrowing posteroventrally; anterior and posteroventral vestibula present. Marginal pore canals short, simple canals throughout. About 20 canals, anteriorly. Hinge merodont. Right valve with terminal crenulated teeth. Crenulations continue into groove for median bar of left valve. Median bar smooth. Normal pores large, of sieve type. Central muscle scars: four elongate adductor scars, others obscure. Eyespot: eyepit large and 'Xestoleberis spot' small. The spot, located low, is short and semicircular in shape.

REMARKs. This species was reported by Brady (I880, p. I26) from only one station (Simon's Bay). Topotypic material: sediment sample M-I64 (Stat. I40) yielded a single right valve, BM I974.388.

\section{Xestoleberis expansa Brady}

(Pl. I9, figs I3, I4)

Xestoleberis expansa Brady, 1880: 129, I30, pl. 30, figs 3a-d.

Lectotype. Left valve, BM 8I.5.4I. Length $0.3 \mathrm{I} \mathrm{mm;} \mathrm{height} 0.19 \mathrm{~mm}$. Type locality: Stat. 323 , off Uruguay, Igoo fathoms. $\left(35^{\circ} 39^{\prime} \mathrm{o}^{\prime \prime} \mathrm{S}, 50^{\circ} 47^{\prime} \mathrm{o}^{\prime \prime} \mathrm{W}\right.$, trawled, grey ooze, bottom temp. $33 \cdot{ }^{\circ} \mathrm{F}$, surface temp. $73 \cdot 5^{\circ} \mathrm{F}$, February 28 , I876.)

DESCRIPTION. Shape and ornamentation as given by Brady (I880). The surface is extremely smooth and polished. Hinge merodont. Central muscle scars consist of four scars and a frontal scar. Eyespot: eyepit and 'Xestoleberis spot' present. 
REMARKs. Brady (I880, p. I29) found one specimen, a complete carapace, which he figured (pl. 30, figs $3 \mathrm{a}-\mathrm{d}$ ). The British Museum slide catalogued as BM 8I.5.4I contained two specimens, a complete carapace figured here on Pl. I9, figs $\mathrm{I}_{3}$ and $\mathrm{I}_{4}$, which, unfortunately, is not a Xestoleberis. Consequently the other specimen, a left valve, is designated lectotype.

\section{Xestoleberis foveolata Brady}

(Pl. I9, figs II, I2)

Xestoleberis foveolata Brady, 1880 : 130, pl. 30, figs ra-g.

LECTOTYPE. Disarticulated right and left valves, BM 80.38.I4I (valves separated after photography). Right valve : length $0.54 \mathrm{~mm}$; height $0.37 \mathrm{~mm}$; left valve : length $0.54 \mathrm{~mm}$; height $0.40 \mathrm{~mm}$. Type locality: Stat. I87, Booby Island, north of Australia, $6-8$ fathoms. $\left(\mathrm{I}^{\circ} 36^{\prime} \mathrm{o}^{\prime \prime} \mathrm{S}\right.$, $\mathrm{I} 4 \mathrm{I}^{\circ} 55^{\prime} \mathrm{o}^{\prime \prime} \mathrm{E}$, dredged, coral and sand, surface, temp. $77 \cdot 7^{\circ} \mathrm{F}$, September 9, I874.)

Description. Shape and ornamentation as given by Brady (I880). See Pl. I9, fig. II. Inner lamella widest anteriorly; anterior and posteroventral vestibula present, the former is wider. Marginal pore canals simple, straight and short. Most numerous anteroventrally. Hinge merodont. Right valve with anterior and posterior crenulate teeth connected by a smooth ridge with a groove above. Left valve with smooth median bar and crenulate sockets joined by a narrow groove and above the latter, an accommodation groove. Normal pores large and open. Central muscle scars: four elongate adductor scars arranged vertically and a frontal scar. Eyespots: eyepit small and not visible externally. 'Xestoleberis spot' long, slender and uniform in width. Overlap: left valve larger than right valve.

REmarks. The type locality is Stat. I87 and topotypes have been recovered from sediment sample M-242 (Stat. I87). Topotypic material: two carapaces, a left and a right valve, BM 1974.364 and 366-8.

\section{Xestoleberis granulosa Brady}

(Pl. I9, figs I7, I8)

Xestoleberis granulosa Brady, 1880: 125, 126, pl. 30, figs 5a-d.

Lectotype. Disarticulated right and left valves, Hancock Museum (valves separated after photography). Right valve : length $0.6 \mathrm{I} \mathrm{mm}$; height $0.33 \mathrm{~mm}$; left valve: length $0.63 \mathrm{~mm}$; height $0.35 \mathrm{~mm}$. Type locality: Port Jackson, Australia, 2-Io fathoms, April 20, I874.

DESCRIPTION. Shape and ornamentation as given by Brady (I880), except for the absence of papillae. Inner lamella wide anteriorly, narrowing towards posterior. Lamella widest posteriorly in region of posteroventral vestibule. Anterior vestibule wider than posterior. Line of concrescence more irregular in anteroventral region, less irregular elsewhere. Marginal pore canals most numerous anteriorly, with 
about 35 simple canals and a few false canals. Concentrated anteroventrally, and less numerous ventrally and posteriorly. Some branching canals occur ventrally. Hinge merodont. Right valve with anterior and posterior crenulate teeth. Left valve with median bar. Bar as prominent as the teeth. Normal pores large and of sieve type. Central muscle scars: a vertical row of four elongate scars and a frontal scar. Eyespot: eyepit obscure. 'Xestoleberis spot' large and about twice as long as wide. Overlap: left valve larger than right.

Remarks. Brady (I880, pp. I25, I26) reported this species from only two localities (Stat. I62, East Moncœur Island, Bass' Strait, 38-40 fathoms, and Port Jackson). The lectotype is from Port Jackson and ro complete carapaces and detached valves were recovered from sediment sample M-I98 (Port Jackson). Topotypic material: a complete carapace, BM 1974.323, and a right valve, BM I974.324.

\section{Xestoleberis nana Brady}

(Pl. 20, figs I4, I5)

Xestoleberis nana Brady, I880 : I26, pl. 31, figs 5a-c.

Lectotype. Right valve, BM 80.38.I43. Length $0.43 \mathrm{~mm}$; height $0.28 \mathrm{~mm}$. Type locality: Stat. I72, off Nukualofa, Tongatabu, I8 fathoms. $\left(20^{\circ} 58^{\prime} \mathrm{o}^{\prime \prime} \mathrm{S}\right.$, I $75^{\circ} \mathrm{Og}^{\prime} \mathrm{o}^{\prime \prime} \mathrm{W}$, dredged, coral, surface temp. $75^{\circ} 0^{\circ} \mathrm{F}$, July 22 , I874.)

DEscription. Shape and ornamentation as given by Brady (I880), see Pl. 20, figs I4 and I5. Inner lamella: see Pl. 20, fig. I5. Widest anteriorly, vestibula present anteriorly and posteroventrally. Marginal pore canals short, simple and straight; about 30 anteriorly with most of them concentrated anteroventrally. Hinge merodont. Right valve with anterior and posterior crenulate teeth and median groove. Normal pores large and open. Many with a 'halo' around the pore on the surface. Central muscle scars: a vertical row of four adductor scars and additional scars. Eyespot: eyepit indistinct, 'Xestoleberis spot' of two distinctly separate slender filaments, one below the other. Both slightly convex anteriorly.

\section{Xestoleberis setigera Brady}

(P1. 20, figs 9-II)

Xestoleberis setigera Brady, 1880 : 125, pl. 31, figs 2a-d and figs $3 a-c$.

Lectotype. Disarticulated right and left valves. Portion of ventral surface of right valve missing, BM 80.38.I45 (valves separated after photography). Right valve: length $0.59 \mathrm{~mm}$; height $0.3 \mathrm{I} \mathrm{mm}$; left valve : length $0.59 \mathrm{~mm}$; height $0.25 \mathrm{~mm}$. Type locality: off Prince Edward's Island, 50-I5o fathoms. $\left(46^{\circ} 48^{\prime} \mathrm{o}^{\prime \prime} \mathrm{S}\right.$, $37^{\circ} 49^{\prime} 30^{\prime \prime} \mathrm{E}$, dredged, grey sand, surface temp. $4 \mathrm{I} \cdot 0^{\circ} \mathrm{F}$, December $26, \mathrm{I} 873$.)

Description. Shape and ornamentation as given by Brady (I880), except for the papillae which are absent in the lectotype but are present in the topotype. Inner 
lamella widest anteriorly; anterior and ventral vestibula present with the former the larger. The ventral vestibule is very narrow and terminates at the posteroventral corner. Marginal pore canals most abundant anteriorly with about 20 simple straight and short canals plus a few false canals anteroventrally. Ventral canals simple and straight. Hinge merodont. Right valve with anterior and posterior crenulate teeth, left valve with smooth median bar. Normal pores large and open. Central muscle scars consist of four scars, the uppermost in the shape of a wide and shallow U. Frontal scar heart-shaped. Eyespot: eyepit present, 'Xestoleberis spot' club shaped. Overlap: left valve larger than right.

REMARKs. Brady (I88o, p. I25) reported this species from three places (off Christmas Harbour, Kerguelen Island, I20 fathoms; the station from which he figured this species; Stat. I5I and off Prince Edward's Island). The lectotype is from Prince Edward's Island. Topotypic material: a complete carapace, BM I974.369, from sediment sample M-I69, Prince Edward's Island.

\section{Xestoleberis tumefacta Brady}

(Pl. 20, figs I2, I3; Pl. 26, figs I-3)

Xestoleberis tumefacta Brady, I880 : I28, I29, pl. 31, figs 4a-d.

Neotype. Complete carapace, BM 1974.370. Length $0.54 \mathrm{~mm}$; height $0.33 \mathrm{~mm}$. Type locality: Nares' Harbour, Admiralty Islands, I6 fathoms, March 2, I875.

Description. Shape as described by Brady (I880). See Pl. 26, figs I-3. Ornamentation, smooth, see Pl. 26, figs I and 2. Inner lamella wide throughout. Hinge merodont. Eyespot: external eyespot absent, but internal 'Xestoleberis spot' is present.

REMARKs. Brady (I880, pp. I28, I29) apparently was dealing with two different forms; the form figured by him (pl. 3I, figs $4 \mathrm{a}-\mathrm{d}$ ) is a true Xestoleberis but in his description he says, 'This has very much the general aspect of Loxoconcha'. The only specimen in the BM collection (BM 8I.5.44) (see Pl. 20, figs $\mathrm{I} 2$ and I3) is a Loxoconcha, the specimen of Xestoleberis being lost. Brady found Loxoconcha pumicosa and Xestoleberis tumefacta only at Nares' Harbour (see p. 24) and several specimens of the only Xestoleberis present at this station were found in sediment sample M-279. One of these is here made neotype and figured (see Pl. 26, figs I-3). Topotypic material: two right valves, BM I974-37I-2.

\section{Xestoleberis variegata Brady}

(Pl. 20, figs $\mathrm{I} 6-\mathrm{I} 8$ )

Xestoleberis variegata Brady, 1880: 129, pl. 31, figs 8a-g.

Lectotype. Disarticulated right and left valves, BM 80.38.I46. Right valve : length $0.52 \mathrm{~mm}$; height $0.37 \mathrm{~mm}$; left valve : length $0.50 \mathrm{~mm}$; height $0.34 \mathrm{~mm}$. 
Type locality: Stats 93, 94, off St Vincent, Cape Verde, I070-II50 fathoms. $\left(\mathrm{I} 6^{\circ} 42^{\prime} \mathrm{o}^{\prime \prime} \mathrm{N}, 25^{\circ} \mathrm{I} 2^{\prime} \mathrm{o}^{\prime \prime} \mathrm{W}\right.$, mud, surface temp. $78 \cdot 0^{\circ} \mathrm{F}$, August 5 , I873.)

Description. Shape as given by Brady (I880) for the left valve, except for the absence of a ventral sinus ; the right valve is characterised by a flat dorsal surface in the region of the median bar/groove and a truncated posterior end, especially the dorsal half. See Pl. 20, figs I6-I8. Ornamentation: the lectotype has only two small opaque spots, both posteriorly rather than variegated all over as indicated by Brady (I880). Inner lamella: anterior and posteroventral vestibula present with the former the widest. Marginal pore canals simple, straight canals, in excess of 20 anteroventrally. Also, numerous ventrally, but decreasing in number posteriorly. Some false canals present. Hinge merodont. Right valve with anterior and posterior crenulate teeth. Left valve with median smooth bar. Normal pores large and open. Central muscle scars: a vertical row of four adductor scars; frontal scar kidney shaped. Eyespot: 'Xestoleberis spot' long and of uniform width except at the dorsal tip where it is narrow. The spot has a coarse granular appearance. Overlap: left valve larger than right.

\section{Genus $\boldsymbol{C Y T H E R U R A}$}

\section{Cytherura clavata Brady}

(Pl. I9, figs 7-IO)

Cytherura clavata Brady, 1880 : 133, pl. 29, figs 7a-d.

Lectotype. Left valve, BM 80.38.I48. Length $0.60 \mathrm{~mm}$; height $0.29 \mathrm{~mm}$. Type locality: Stat. $3 \mathrm{I} 6$, Stanley Harbour, Falkland Islands, 6 fathoms. $\quad\left(5 \mathrm{I}^{\circ} 32^{\prime} \mathrm{o}^{\prime \prime} \mathrm{N}\right.$, $58^{\circ} 0^{\prime} \mathrm{o}^{\prime \prime} \mathrm{W}$, dredged, 4 fathoms, mud, surface temp. $5 \mathrm{I} \cdot 2^{\circ} \mathrm{F}$, February 3 , I876.)

Description. Shape and ornamentation: see Brady (I880).

\section{Cytherura clausi Brady}

(Pl. 2I, figs 9, I0)

Cytherura clausi Brady, 1880 : 134, pl. 32, figs 8a-d.

Lectotype. Left valve, BM 81.5.47. Length $0.49 \mathrm{~mm}$; height $0.26 \mathrm{~mm}$. Type locality: Stat. I40, Simon's Bay, South Africa, I5-20 fathoms, October 1873.

Description. Shape and ornamentation as given by Brady. Surface strongly reticulate. Inner lamella very wide anteriorly where the inner margin runs a normal course; very wide posteriorly where it forms a strong curve. Normal pores moderately small, numerous, open.

Remarks. Brady's syntypes (BM 8I.5.I7 and BM 8I.5.45) labelled 'Cytherura clausi' really represent $C$. mucronata Brady. Several specimens of $C$. clausi Brady were found in sediment sample M-I64. Hornibrook (I952, p. 5I, pl. I5, figs 242244) reported and figured Cytherura clausi Brady from New Zealand, conspecific with the form described here. 


\section{Cytherura costellata Brady}

(Pl. 2I, figs 7,8 )

Cytherura costellata Brady, 1880 : 134, pl. 32, figs 7a-d.

Lectotype. Right valve, BM 80.38.I49. Length $0.47 \mathrm{~mm}$; height $0.23 \mathrm{~mm}$. Type locality: Stat. I49, Balfour Bay, Kerguelen Island, 20-50 fathoms, mud, January I874.

DESCRIPTION. Shape and ornamentation as described by Brady (I880).

\section{Cytherura cribrosa Brady}

(Pl. 2I, fig. 2)

Cytherura cribrosa Brady, 1880: 132, pl. 32, figs 5a-d.

Lectotype. Whole carapace, BM 80.38.I50. Length $0.59 \mathrm{~mm}$; height $0.37 \mathrm{~mm}$. Type locality: Stat. 305 , I6o fathoms. $\left(47^{\circ} 48^{\prime} 0^{\prime \prime} \mathrm{S}, 74^{\circ} 46^{\prime} \mathrm{o}^{\prime \prime} \mathrm{W}\right.$, trawled, mud, surface temp. $55^{\circ} 0^{\circ} \mathrm{F}$, January I, I876.)

DESCRIPTION. Shape and ornamentation as described by Brady (I880).

\section{Cytherura cryptifera Brady}

(Pl. 2I, fig. I)

Cytherura cryptifera Brady, 1880: 134, 135, pl. 32, figs 4a-c.

Lectotype. Left valve (damaged) Hancock Museum. Length $0.40 \mathrm{~mm}$; height $0.22 \mathrm{~mm}$. Type locality: Stat. I62, off East Moncœur Island, Bass Strait, 38-40 fathoms. $\left(39^{\circ} \mathrm{Io}^{\prime} 30^{\prime \prime} \mathrm{S}, 146^{\circ} 37^{\prime} \mathrm{O}^{\prime \prime} \mathrm{E}\right.$, dredged, sand, surface temp. $63 \cdot 2^{\circ} \mathrm{F}$, April 2, I874.)

DESCRIPTION. Shape and ornamentation as described by Brady (I880).

\section{Cytherura curvistriata Brady}

(Pl. 2I, fig. I3)

Cytherura curvistriata Brady, 1880 : 131, pl. 32, figs roa-d.

Lectotype. Whole carapace, BM 8I.5.46. Length $0.37 \mathrm{~mm}$; height $0.2 \mathrm{I} \mathrm{mm}$. Type locality: Port Jackson, Australia, 2-Io fathoms, April 20, I874.

Description. Shape and ornamentation as described by Brady (I880).

\section{Cytherura lilljeborgi Brady}

(Pl. 2I, figs 3-6)

Cytherura lilljeborgi Brady, I880: 132, I33, pl. 32, figs 6a-d.

Lectotype. Whole carapace, BM 80.38.I5I. Length $0.43 \mathrm{~mm}$; height $0.25 \mathrm{~mm}$. Type locality: Stat. I49, Balfour Bay, Kerguelen Island, 20-50 fathoms, mud, January I874.

Description. Shape and ornamentation as described by Brady (I880). 


\section{Cytherura mucronata Brady}

(P1. 2I, figs II, I2)

Cytherura mucronata Brady, I880: 133, 134, pl. 32, figs 9a-d.

Lectotype. Whole carapace, BM 8I.5.45. Length $0.50 \mathrm{~mm}$; height $0.28 \mathrm{~mm}$. Type locality: Stat. I40, Simon's Bay, South Africa, I5-20 fathoms, October I8, I873.

Description. Shape and ornamentation as described by Brady (I880). See Pl. 2I, fig. II.

Remarks. Brady (I880, pp. I33, I34) described both Cytherura mucronata and Cytherura clausi from Stat. I40 (Simon's Bay). The lectotype of C. mucronata (BM 8I.5.45) and syntype specimens labelled by Brady as ' $C$. clausi' really represent C. mucronata. Several specimens of Brady's C. clausi were found in sediment sample M-I64 (Stat. I40).

\section{Genus CYTHEROPTERON \\ Cytheropteron abyssorum Brady}

(P1. 23, fig. 8)

Cytheropteron abyssorum Brady, I880 : 138, pl. 34, figs 3a-d.

LECTотуPE. Whole carapace, BM 8I.5.49. Length $0.37 \mathrm{~mm}$; width (from ala of right to ala of left valve) $0.50 \mathrm{~mm}$. Type locality: Stat. I60, Southern Australian Basin, 2600 fathoms. $\left(42^{\circ} 42^{\prime} \mathrm{O}^{\prime \prime} \mathrm{S}, 134^{\circ} \mathrm{IO}^{\prime} \mathrm{O}^{\prime \prime} \mathrm{E}\right.$, trawled, red clay, bottom temp. $33.9^{\circ} \mathrm{F}$, surface temp. $55^{\circ} 0^{\circ} \mathrm{F}$, March I3, I874.)

DESCRIPTION. Shape: a large portion of each valve is missing and no attempt was made to study the specimen in detail. The description given by Brady (I880) fits the lectotype.

\section{Cytheropteron (?) angustatum Brady}

(Pl. 23, figs $\mathrm{I} 5-\mathrm{I} 7$ )

Cytheropteron (?) angustatum Brady, 1880 : 137, pl. 34, figs 5a, b ('angustum' on explanation to pl. 34).

Lectotype. Left valve, BM 80.38.I52. Length $0.46 \mathrm{~mm}$; height $0.28 \mathrm{~mm}$. Type locality: Stat. I49, Balfour Bay, Kerguelen Island, 20-50 fathoms, mud, January I874.

Description. Shape as given by Brady (I880), except that the entire dorsal margin slopes towards the posterior. See Pl. 23, figs 15 and I6. Ornamentation as given by Brady (I880). Inner lamella widest at anterior end. Line of concrescence and inner margin coincide throughout, no vestibule at either end. Hinge of Infracytheropteron type (holoperatodont). Central muscle scars: see Pl. 23, fig. I7.

Remarks. Brady (I880, p. I37) reported this species from Stat. I49 (Balfour Bay) and Stat. I85 (Torres' Straits, I55 fathoms) and he figured a left valve (pl. 34, 
figs $5 \mathrm{a}, \mathrm{b})$. The lectotype is also a left valve from Stat. I49. Topotypic material: sediment sample M-237 (Stat. I85) yielded a single right valve, BM I974.375.

\section{Cytheropteron assimile Brady}

(Pl. 23, figs $\mathrm{I}-7$ )

Cytheropteron assimile Brady, 1880 : 138, 139, pl. 34, figs 2a-d.

LEctotype. Whole carapace, BM 80.38.153. Length $0.70 \mathrm{~mm}$; height $0.42 \mathrm{~mm}$. Type locality: Stat. I5I, off Heard Island, 75 fathoms. $\left(52^{\circ} 59^{\prime} 30^{\prime \prime} \mathrm{S}, 73^{\circ} 33^{\prime} 30^{\prime \prime} \mathrm{E}\right.$, dredged, mud, surface temp. $36 \cdot 2^{\circ} \mathrm{F}$, February 7 , I874.)

Description. Shape as described by Brady (I880), except for posterior portion of dorsal margin. See Pl. 23, fig. I. Ornamentation as given by Brady (I880). Inner lamella: vestibule present at anterior end. Otherwise line of concrescence and inner margin coincide. Marginal pore canals few in number and most are simple. Hinge with only the terminal portions of the median element crenulate, see Pl. 23, figs 3-7. Normal pores open and scattered. Central muscle scars: four undivided adductors. Frontal scar single and V-shaped.

REMARKs. Brady (I880, pp. I38, I39) described this species from off Christmas Harbour (Stat. I49) and off Heard Island (Stat. I5I). The lectotype is from Stat. I5I. Topotypic material: this species is common in sediment sample M-I83 (Stat. I49) and two right valves and a left valve are registered, BM I974.376-8.

\section{Cytheropteron fenestratum Brady}

(Pl. 23, fig. I8; Pl. 24, figs I-6)

Cytheropteron fenestratum Brady, I880 : 139, 140, pl. 34, figs 6a-d.

LECTOTYPE. Right valve, BM 80.38.I54-I55. Length $0.93 \mathrm{~mm}$; height $0.56 \mathrm{~mm}$. Type locality: Stat. I49, off Christmas Harbour, Kerguelen Island, I20 fathoms. $\left(48^{\circ} 43^{\prime} 45^{\prime \prime} \mathrm{S}, 69^{\circ} 6^{\prime} \mathrm{I}^{\prime \prime} \mathrm{E}\right.$, dredged, mud, surface temp. $38 \cdot 8-39^{\circ} 0^{\circ} \mathrm{F}$, January 29, I874.)

Description. Shape and ornamentation as described by Brady (I880), except that the ventral surface is not 'irregularly nodulated'. Inner lamella: see Pl. 23, fig. I8. Line of concrescence and inner margin coincide except anteriorly where a vestibule is present. Marginal pore canals numerous and mostly simple. Hinge: see Pl. 24, figs 5 and 6 . Terminal elements lobed, groove of median element smooth. Normal pores, numerous, scattered and open. Central muscle scars: five adductor scars arranged in a vertical row; middle three more elongate than the dorsal- or ventralmost scars. Single frontal scar.

REMARKs. Brady (I880, pp. I39, I40) reported this species from two stations (I49 and 335). He figured a complete carapace (pl. 34, figs 6a-d). The lectotype is a right valve from Stat. I49. Topotypic material: sediment sample M-I83 (Stat. I49, off Christmas Harbour) yielded a right valve, BM I974.379. 


\section{Cytheropteron mucronalatum Brady}

(P1. 22, figs I4-I8)

Cytheropteron mucronalatum Brady, I880: I40, I4I, pl. 33, figs 8a-d.

Lectotype. Left valve, BM 8o.38.I57. Length $\mathrm{I} \cdot 30 \mathrm{~mm}$; height $0.84 \mathrm{~mm}$. Type locality: Stat. 296, near the Chile Rise in the eastern Pacific, I825 fathoms. $\left(3^{\circ} 6^{\prime} \mathrm{o}^{\prime \prime} \mathrm{S}, 88^{\circ} 2^{\prime} \mathrm{o}^{\prime \prime} \mathrm{W}\right.$, trawled, Globigerina ooze, bottom temp. $35 \cdot 3^{\circ} \mathrm{F}$, surface temp. $59 \cdot 8^{\circ} \mathrm{F}$, November 9 , I 875 .)

Description. Shape: the lectotype differs from description of $C$. mucronalatum by Brady (I880) in the following ways : height is not equal to more than two-thirds of the length, anterior end scarcely dentate, posterior end devoid of spines, dorsum not broadly arched, see P1. 22, figs $\mathrm{I}_{5}$ and I8. Ornamentation: the elevated ridge mentioned by Brady ( $\mathrm{I} 880$ ) is practically absent anteriorly and does not terminate in a strong short spine on the lectotype. Right valve does show the spine. Inner lamella: line of concrescence and inner margin coincide, vestibula absent. Marginal pore canals few, mostly simple, few false. Hinge: median element smooth. Normal pores, scattered and open. Central muscle scars: see Pl. 22, figs I5 and I7.

Remarks. Brady (I880, pp. I40, I4I) described this species from Stats 70, 224, 246, 296, 300 and 302 and he figured a complete carapace (pl. 33, figs 8a-d). The lectotype is a right valve from Stat. 296. Topotypic material: sediment sample $\mathrm{M}-92$ (Stat. $70,38^{\circ} 25^{\prime} \mathrm{o}^{\prime \prime} \mathrm{N}, 35^{\circ} 50^{\prime} \mathrm{o}^{\prime \prime} \mathrm{W}, \mathrm{I} 675$ fathoms) yielded a single left valve, BM I974.380.

\section{Cytheropteron patagoniense Brady}

(P1. 22, figs I2, I3)

Cytheropteron patagoniense Brady, 1880 : 139, pl. 33, figs 7a-d.

Leстотуре. Left valve, eroded, BM 80.38.I58. Length $0.56 \mathrm{~mm}$; height $0.37 \mathrm{~mm}$. Type locality: Stat. 305 , I6o fathoms. $\left(47^{\circ} 48^{\prime} \mathrm{o}^{\prime \prime S}, 74^{\circ} 46^{\prime} \mathrm{o}^{\prime \prime} \mathrm{W}\right.$, trawled, mud, surface temp. $55^{\circ} 0^{\circ} \mathrm{F}$, January I, I876.)

Description. Shape: see Pl. 22, fig. I2. Exceptions to Brady's (I880) description include broadly rounded anterior, anterior half of dorsal margin regular and gently sloping, posterior half of dorsal margin steeply sloping. Ornamentation: the ridge mentioned by Brady is absent on the lectotype. A posterior dorsal knob is present at about the position where the ridge terminates on Brady's specimen. Hinge: median element smooth. Central muscle scars: four adductor scars with single kidney-shaped frontal scar.

\section{Cytheropteron scaphoides Brady}

$$
\text { (Pl. 2I, figs I4-I8) }
$$

Cytheropteron scaphoides Brady, 1880 : 136, pl. 33, figs ra-d.

Lectotype. Disarticulated right and left valves, BM 80.38.I59. Right valve: length $0.37 \mathrm{~mm}$; height $0.19 \mathrm{~mm}$; left valve : length $0.37 \mathrm{~mm}$; height $0.15 \mathrm{~mm}$. 
Type locality: Stat. I49, Balfour Bay, Kerguelen Island, 20-50 fathoms, mud, January 1874 .

DESCRIPTION. Shape and ornamentation as given by Brady (I880). Inner lamella: anterior and posterior vestibula present with the former the larger of the two. Marginal pore canals few and simple. Hinge as follows: in the larger right valve, the sequence of elements anterior to posterior is socket, wedge-shaped (in dorsal view) tooth, crenulate bar, rounded (in dorsal view) tooth, socket. In smaller left valve, crenulate groove, socket, wedge-shaped tooth. In both valves, the high point of the wedge is towards the anterior end. See Pl. 2I, figs I7 and I8. Central muscle scars: adductor scars consist of four adjacent but distinct scars arranged in a vertical row. Frontal scar single somewhat circular and large. Overlap: right valve larger than left.

\section{Cytheropteron wellingtoniense Brady}

(P1. 23, figs 9-I4)

Cytheropteron wellingtoniense Brady, 1880 : 136, 137, pl. 34, figs 4a-d.

LEстотуре. Right and left valves of a once articulated specimen, BM 80.38.I60. Right valve: length $0.56 \mathrm{~mm}$; height $0.34 \mathrm{~mm}$. Type locality: Wellington Harbour, New Zealand, depth unknown.

Description. Shape essentially as given by Brady (I880). Notable exception is prominent indentation in dorso-anterior region. See Pl. 23, fig. Io. Ornamentation as given by Brady (1880). Inner lamella: anterior vestibule present. Hinge: see Pl. 23, figs II-I3; terminal and median element crenulate. Central muscle scars: see Pl. 23, fig. I4, frontal scar V-shaped.

\section{Genus BYTHOCYTHERE \\ Bythocythere arenacea Brady}

(P1. 22, figs I-5)

Bythocythere arenacea Brady, $1880: 142$, pl. 33, figs 3a-g (arenosa on pl. 19).

Lectotype. Left valve, BM 81.5.50. Length $0.75 \mathrm{~mm}$; height $0.37 \mathrm{~mm}$. Tip of posterior caudal process broken off and missing. Type locality: Stat. I85, Torres' Straits, I55 fathoms. $\left(\mathrm{II}^{\circ} 35^{\prime} \mathrm{O}^{\prime \prime} \mathrm{S}, \mathrm{I} 44^{\circ} 3^{\prime} \mathrm{O}^{\prime \prime} \mathrm{E}\right.$, dredged, sand and shells, surface temp. $77^{\circ} 0^{\circ} \mathrm{F}$, August 3I, I874.)

DEscription. Shape and ornamentation as described by Brady (I880). See P1. 22, fig. I. Inner lamella: see Pl. 22, figs 2 and 3. Well defined anterior vestibule present. Hinge: see P1. 22, figs 4 and 5. Central muscle scars: five, arcuate, vertically arranged, elongate adductor scars and two frontal scars.

Remarks. Brady (I880, p. I42) found 'several examples' from Stat. I85 and figured (see pl. 33, fig. 3) complete carapaces of both a male and a female. Topotypic material: two specimens, both left valves, were found in sediment sample M-237 ; one left valve is registered BM I974.382. 


\section{Bythocythere (?) exigua Brady}

(Pl. 3, figs 6-Io)

Bythocythere (?) exigua Brady, I880: I43, I44, pl. 6, figs 7a-d (exigna on pl. 6).

Lectotype. Disarticulated right and left valves, BM 81.5.5I. Right valve : length $0.50 \mathrm{~mm}$; height $0.28 \mathrm{~mm}$; left valve : length $0.50 \mathrm{~mm}$; height $0.28 \mathrm{~mm}$. Type locality: Stat. 3I 3 , Straits of Magellan, 55 fathoms. $\left(52^{\circ} 2 \mathrm{I}^{\prime} \mathrm{o}^{\prime \prime} \mathrm{S}, 68^{\circ} \mathrm{o}^{\prime} \mathrm{o}^{\prime \prime} \mathrm{W}\right.$, trawled, sand, bottom temp. $47 \cdot 8^{\circ} \mathrm{F}$, surface temp. $48 \cdot 2^{\circ} \mathrm{F}$, January 20,1876 .)

DESCRIPTION. Shape and ornamentation as described by Brady (I880).

\section{Bythocythere pumilio Brady}

(P1. 22, figs 6-8)

Bythocythere pumilio Brady, I880 : I42, I43, pl. 33, figs 4a-d.

Lectotype. Whole carapace, BM 8I.5.52. Length $0.45 \mathrm{~mm}$; height $0.2 \mathrm{I} \mathrm{mm}$. Type locality: Stat. I49, Balfour Bay, Kerguelen Island, 20-50 fathoms, mud, January 1874 .

Description. Shape and ornamentation as described by Brady (I880).

\section{Bythocythere velifera Brady}

(Pl. 22, figs 9-II; Pl. 27, fig. 3)

Bythocythere velifera Brady, I880: I43, pl. 33, figs 5a-c.

Neotype. Left valve, BM I974.38I. Length $0.59 \mathrm{~mm}$; height $0.47 \mathrm{~mm}$. Type locality: Stat. I85, Torres' Straits, $\mathrm{I} 55$ fathoms. ( $\mathrm{II}^{\circ} 35^{\prime} \mathrm{O}^{\prime \prime} \mathrm{S}, \mathrm{I} 44^{\circ} 3^{\prime} \mathrm{O}$ "E, dredged, sand and shells, surface temp. $77 \cdot 0^{\circ} \mathrm{F}$, August $3 \mathrm{I}, \mathrm{I} 874$.)

Description. Shape and ornamentation as described by Brady (I880).

REMARKs. The only specimen in the British Museum labelled Bythocythere velifera (BM 8I.5.53) is a Cytheropteron (see Pl. 22, figs 9-II), one of the two velate Bythocythere specimens found at the type locality is designated neotype.

\section{Genus PSEUDOCYTHERE Pseudocythere fuegiensis Brady \\ (Pl. I, figs 9, Io)}

Pseudocythere fuegiensis Brady, I880 : 145, pl. I, figs 7a-d.

Holotype. Right valve, BM 8I.5.54. (This is the only specimen found by Brady and figured as $7 \mathrm{a}-\mathrm{c}$.) Length $\mathrm{I} \cdot \mathrm{I} 8 \mathrm{~mm}$; height $0.50 \mathrm{~mm}$. Type locality: Stat. 3II, 245 fathoms. $\left(52^{\circ} 5 \mathrm{I}^{\prime} \mathrm{O}^{\prime \prime} \mathrm{S}, 73^{\circ} 53^{\prime} \mathrm{o}^{\prime \prime} \mathrm{W}\right.$, trawled, mud, bottom temp. $46 \cdot 0^{\circ} \mathrm{F}$, surface temp. $50^{\circ} 0^{\circ} \mathrm{F}$, January II, I 876 .) 
DESCRIPTION. Shape and ornamentation as given by Brady (I880), except that the longitudinal striae are present over the entire surface but stronger in the posterior half. Inner lamella: anterior and posteroventral vestibula present, see Pl. I, fig. 9 . Marginal pore canals straight and simple. Cluster of three near centre of caudal process. Hinge adont. Central muscle scars: see Pl. I, fig. Io.

\title{
Genus CYTHERIDEIS
}

Cytherideis laevata Brady

(Pl. 2, fig. I8; Pl. 3, figs I-5)

Cytherideis laevata Brady, 1880 : 146, I47, pl. 6, figs 5a-d; pl. 35, figs 6a-d.

Lectotype. Disarticulated right and left valves, BM 80.38.r64. Right valve : length $0.88 \mathrm{~mm}$; height $0.34 \mathrm{~mm}$; left valve : length $0.90 \mathrm{~mm}$; height $0.34 \mathrm{~mm}$. Type locality: Stat. I5I, off Heard Island, 75 fathoms. $\left(52^{\circ} 59^{\prime} 30^{\prime \prime} \mathrm{S}, 73^{\circ} 33^{\prime} 30^{\prime \prime} \mathrm{E}\right.$, dredged, mud, surface temp. $36 \cdot 2^{\circ} \mathrm{F}$, February 7 , I874.)

Description. Shape and ornamentation as described by Brady (I880), see Pl. 2, fig. I8. Hinge adont, see Pl. 3, fig. 3. Central muscle scars: see Pl. 3, fig. 2.

REMARKs. Brady (I880, pp. I46, I47) did not mention the frequency of this species and he figures two complete carapaces (pl. 6, fig. 5 ; pl. 35, fig. 6). Topotypic material: this species is a common form in the sediment sample M-I85 and a right and a left valve are registered BM I974.385-6.

\section{Genus XIPHICHILUS}

\section{Xiphichilus (?) arcuatus Brady}

\author{
(P1. 24, figs 7,8 )
}

Xiphichilus (?) arcuatus Brady, 1880: 148, 149, pl. 35, figs 2a-d.

Lectotype. Disarticulated right and left valves, BM 8r.5.55. Right valve : length $0.53 \mathrm{~mm}$; height $0.19 \mathrm{~mm}$; left valve : length $0.53 \mathrm{~mm}$; height $0.19 \mathrm{~mm}$. Type locality: Stat. I74c, 6ro fathoms. ( $19^{\circ} 07^{\prime} 50^{\prime \prime} \mathrm{S}, 178^{\circ} \mathrm{I}^{\prime} 35^{\prime \prime} \mathrm{E}$, trawled, Globigerina ooze, bottom temp. $39^{\circ} 0^{\circ} \mathrm{F}$, surface temp. $78 \cdot 0^{\circ} \mathrm{F}$, August $3, \mathrm{I} 874$. )

Description. Shape: the lectotype differs from the description by Brady (I880) in that the anterior end is more rounded, ventral margin slightly concave anteriorly and convex posteriorly. Ornamentation: entire surface with many small longitudinal ridges that follow the general curvature of the dorsum. Ridges can be seen with transmitted light. Inner lamella widest anteriorly where a vestibule is present. Elsewhere the line of concrescence and inner margin coincide. Marginal pore canals few, straight and mostly single. Few false canals ventrally. Hinge merodontlophodont. Right valve with small, terminal teeth and a long groove between. Left valve with a long smooth median bar between terminal sockets, the posterior 
tooth is the largest. Central muscle scars: adductor scars consist of four closely adjacent scars.

\section{Xiphichilus complanatus Brady}

Xiphichilus complanatus Brady, 1880 : 148 , pl. 35 , figs $4 \mathrm{a}-\mathrm{d}$.

Lectotype. Left valve, BM 8r.5.56 [specimen lost]. Type locality: Stat. I49, off Christmas Harbour, Kerguelen Island, I20 fathoms, January 29, I874.

Description. Shape as given by Brady (I880). Inner lamella, very wide anteriorly and posteriorly. Hinge adont. Normal pores frequent, open.

Remarks. Brady described this species only from Stat. I49. Three specimens (one adult and two juveniles) were found in sediment sample M-I83. Topotypic material: a complete carapace, BM I974.253.

\section{Genus POL YCOPE \\ (?) Polycope cingulata Brady}

(P1. 26, fig. 4)

Polycope cingulata Brady, I880 : I7o, pl. 35 , figs $7 \mathrm{a}-\mathrm{d}$.

Material. Complete carapace, BM I974.384. Length $0.49 \mathrm{~mm}$. Type locality: None. Brady (I880, p. I70) mentioned that there is no record of the locality in which the only specimen of this species was found.

Remarks. A single complete, eroded carapace, which may represent Polycope cingulata, was found in sediment sample M-I98 (which represents Challenger Stat. Port Jackson, Australia, 2-Io fathoms, April 20, 1874.) The only articulated specimen which was figured by Brady as $7 \mathrm{a}-\mathrm{d}$ on pl. 35 was never deposited either in the British Museum (Natural History) or in the Hancock Museum ( fide letter by Mrs O. Marshall, secretary to Mr A. M. Tynan, Curator, Hancock Museum, dated 24 July I967 to H. S. Puri).

\section{Polycope (?) favus Brady}

(P1. 24, fig. 9)

Polycope (?) favus Brady, I88o : I7o, pl. 36, figs 4a-b.

Lectotype. Left valve, BM 8r.5.64. Length $0.44 \mathrm{~mm}$; height $0.40 \mathrm{~mm}$. Type locality: Stat. I85, Torres' Straits, 155 fathoms. ( $\mathrm{IO}^{\circ} 35^{\prime} \mathrm{O}^{\prime \prime} \mathrm{S}, \mathrm{I} 44^{\circ}{ }^{\circ} 3^{\prime} \mathrm{o}^{\prime \prime} \mathrm{E}$, dredged, sand and shells, surface temp. $77^{\circ} 0^{\circ} \mathrm{F}$, August 3I, I874.)

Description. Shape and ornamentation as described by Brady (I880). 
Remarks. Brady (I880, p. I70) found 'one or two' valves from Stat. I85, and he figured a left valve. Topotypic material: two valves, one broken, were found from sediment sample M-237. A left valve is registered BM I974.383.

\title{
Genus CYTHERELLA \\ Cytherella cribrosa Brady
}

\author{
(Pl. I7, fig. I3)
}

Cytherella cribrosa Brady, 1880 : 176, pl. 26, figs 5a-c.

Lectotype. Left valve, BM 8r.5.66. Length o.62 mm; height $0.34 \mathrm{~mm}$. Type locality: Stat. I72, off Nuknalofa, Tongatabu, I 8 fathoms. $\left(20^{\circ} 5^{\circ} \mathrm{o}^{\prime \prime} \mathrm{S}, \mathrm{I} 75^{\circ} \mathrm{og} \mathrm{g}^{\prime \prime} \mathrm{W}\right.$, dredged, coral, mud, surface temp. $75^{\circ} 0^{\circ} \mathrm{F}$, July 22 , I874.)

Remarks. The form described and illustrated by Brady does not resemble the lectotype. Brady (I880, p. I76) observed that the 'surface of the shell is destitute of ridges or undulations, but marked with numerous rather large oblong excavations'. The left valve figured by him as figs $5 \mathrm{a}-\mathrm{c}$ is not as long $(0.49 \mathrm{~mm})$ as the lectotype $(0.62 \mathrm{~mm})$ which is obviously a Cytherelloidea. We have designated this specimen the lectotype as it was the only specimen found in the collection labelled as ' $C y$ therella cribrosa, No. I72, D.I8, off Tongatabu'. This is the only species of Cytherella in the dredging at Stat. I72, and Brady found it only at its type locality.

\section{Cytherella dromedaria Brady}

(Pl. 24, fig. I4)

Cytherella dromedaria Brady, 1880 : 173, pl. 43, figs 6a-b.

Lectotype. Left valve, BM 8r.5.67. Length $0.77 \mathrm{~mm}$; height $0.47 \mathrm{~mm}$. Type locality: Stat. I40, Simon's Bay, South Africa, I5-20 fathoms, October 1873.

Remarks. Brady (I880, p. I73) described this species from Stat. I40 (Simon's Bay) and he figured a left valve (pl. 43, figs 6a-b). The lectotype is also a left valve from Simon's Bay. Topotypic material: sediment sample M-I64 (Simon's Bay, Stat. I40) yielded a right valve and a left valve, BM I974.357-8.

\section{Cytherella irregularis Brady}

(Pl. 24, fig. I0)

Cytherella irregularis Brady, 1880 : 178, pl. 43, figs 3a-c.

Lectotype. Left valve (damaged), Hancock Museum. (Same specimen as illustrated by Brady, pl. 43, figs $3 a-c$, photographed on original museum slide as the specimen is too fragile to transfer.) Length $0.72 \mathrm{~mm}$; height $0.33 \mathrm{~mm}$. Type locality: Stat. 33, off Bermuda, 435 fathoms. $\left(32^{\circ} 2 \mathrm{I}^{\prime} 30^{\prime \prime} \mathrm{N}, 64^{\circ} 35^{\prime} 55^{\prime \prime} \mathrm{W}\right.$, dredged, coral mud, surface temp. $68.0^{\circ} \mathrm{F}$, April 4 , I873.)

Description. Shape and ornamentation as described by Brady (I880), see Pl. 24, fig. Io. 
Cytherella lata Brady

(P1. 24, figs I7, I8)

Cytherella lata Brady, I880: I73, pl. 44, figs 5a-e.

Lectotype. Right valve, BM 80.38.I72. Length 0.8I mm; height $0.56 \mathrm{~mm}$. Type locality: Stat. 75, off Azores, $45^{\circ}$ fathoms. $\left(38^{\circ} 38^{\prime} \mathrm{o}^{\prime \prime} \mathrm{N}, 28^{\circ} 28^{\prime} 30^{\prime \prime} \mathrm{W}\right.$, dredged, sand, surface temp. $70^{\circ} 0^{\circ} \mathrm{F}$, July 2 , I873.)

Description. Shape and ornamentation as described by Brady (I880), see Pl. 24, fig. I7. Central muscle scars: two curved transverse rows of six and nine elongate scars respectively.

REMARKs. Brady (I88o, p. I73) reported this species from the following stations : off Culebra Island, West Indies, 390 fathoms, mud (Stat. 24); off Azores, lat. $38^{\circ} 37^{\prime} \mathrm{o}^{\prime \prime} \mathrm{N}$, long. $28^{\circ} 30^{\prime} \mathrm{o}^{\prime \prime} \mathrm{W}, 45^{\circ}$ fathoms, sand (Stat. 75) ; off Pernambuco, lat. $8^{\circ} 37^{\prime} \mathrm{o}^{\prime \prime} \mathrm{S}$, long. $34^{\circ} 28^{\prime} \mathrm{o}^{\prime \prime} \mathrm{W}, 675$ fathoms, mud (Stat. I20); Torres' Straits, lat. $\mathrm{II}^{\circ} 35^{\prime} \mathrm{O}^{\prime \prime} \mathrm{S}$, long. I $44^{\circ} \mathrm{O}^{\prime} \mathrm{O}^{\prime \prime} \mathrm{E}$, I55 fathoms, sand (Stat. I85); off Ki Islands, 580 fathoms, lat. $5^{\circ} 26^{\prime} \mathrm{o}^{\prime \prime} \mathrm{S}$, long. I33 ${ }^{\circ} \mathrm{Ig}^{\prime} \mathrm{o}^{\prime \prime} \mathrm{S}$, mud (Stat. I9Ia). The lectotype is from Stat. 75. Topotypic material: a left valve recovered from sediment sample M-237 (Stat. I85), BM I974.389.

\section{Cytherella latimarginata Brady}

(Pl. I7, figs $\mathrm{I}_{4}, \mathrm{I} 5$ )

Cytherella latimarginata Brady, I880 : I78, I79, pl. 36, figs 7a-d.

Neotype. Disarticulated left and right valves, BM 8I.5.69. Right valve : length $0.4 \mathrm{I} \mathrm{mm}$; height $0.28 \mathrm{~mm}$; left valve: length $0.4 \mathrm{I} \mathrm{mm}$; height $0.25 \mathrm{~mm}$. Type locality: Stat. I85, Torres' Straits, I55 fathoms. ( $\mathrm{II}^{\circ} 35^{\prime} \mathrm{O}^{\prime \prime} \mathrm{S}$, I $44^{\circ}{ }^{\circ} 3^{\prime} \mathrm{O}^{\prime \prime} \mathrm{E}$, dredged, sand and shells, surface temp. $77^{\circ} 0^{\circ} \mathrm{F}$, August 3I, I874.)

Description. Shape and ornamentation as described by Brady (I880), see Pl. I7, figs $\mathrm{I}_{4}$ and $\mathrm{I} 5$.

Remarks. Specimens of this species were never deposited either in the British Museum (Natural History) or the Hancock Museum (letter by Mrs O. Marshall, secretary to Mr A. M. Tynan, Curator, Hancock Museum, dated 24 July I967, to H. S. Puri) and have been lost. Sediment sample M-237 (Stat. I85) yielded a single articulated valve, which is designated as neotype.

\section{Cytherella venusta Brady}

(P1. 24, figs II-I3)

Cytherella venusta Brady, I880: I76, pl. 43, figs 4a-d.

Lectotype. Right valve, BM 80.38.I80. Length 0.7I mm; height $0.34 \mathrm{~mm}$. Type locality: off reefs at Honolulu, 40 fathoms, July I875.

Description. Shape and ornamentation as described by Brady (I880), see Pl. 24, figs II and I3. Central muscle scars: see P1. 24, fig. I2. 
Remarks. Off reefs at Honolulu is the only locality where Brady (I880, p. I 76 ) found this species. Topotypic material: sediment sample M-324, which represents the type locality, yielded a right and a left valve, which are designated topotypes BM I974.390-I.

\section{REFERENCES}

BAte, R. H. I963. The Ostracoda collected during the voyage of H.M.S. Challenger. Micropaleontology $9: 79-84$.

Benson, R. H. I971. A new Cenozoic deep-sea genus, Abyssocythere (Crustacea : Ostracoda . Trachyleberididae), with description of five new species. Smithson, Contr. Paleobiol: 7: $\mathbf{1}-25,3$ pls.

- 1972. The Bradleya problem. With descriptions of two new psychrospheric ostracode genera, Argenocythere and Poseidonamicus (Ostracoda: Crustacea). Smithson. Contr. Paleobiol. 12 : I-138, I4 pls, 67 figs.

BRADy, G. S. I866. On new or imperfectly known species of marine Ostracoda. Trans. zool. Soc. Lond. 5 : 359-393, pls 57-62.

- 1867-1871. In: Les Fonds de la Mer, vol. I.

I878. A monograph of the Ostracoda of the Antwerp Crag. Trans. zool. Soc. Lond. 10 (8) : 379-409, pls 62-69.

I880. Report on the Ostracoda dredged by 'H.M.S. Challenger' during the years I8731876. Rep. scient. Results Voy. Challenger 1 (3) : I-I84, 44 pls.

- 1898. On new or imperfectly known species of Ostracoda, chiefly from New Zealand. Trans. zool. Soc. Lond. $14: 429-45^{2}$, pls $43-47$.

Cornuel, J. I846. Description des entomostraces fossils du terrain Crétace inférieur du Département de la Haute-Marne suivie d'indications sur les profondeurs de la mer qui a déposé ce terrain. Mém. Soc. géol. Fr. ser. I, 1 (2) : 193-205, 7 pls.

Harding, J. P. \& Sylvester-Bradley, P. C. I953. The ostracode genus Trachyleberis. Bull. Br. Mus. nat. Hist. (Zool.) 2 : I-15, 2 pls.

Hornibrook, N. De B. I952. Tertiary and Recent marine Ostracoda of New Zealand. Palaeont. Bull. Wellington, 18 : 1082, pls $\mathrm{I}-\mathrm{I} 8$.

Neviani, A. 1928. Ostracodi fossil d'Italia. I. Vallebiaja (Calabriano). Memorie Accad. pont. Nuovi Lincei ser. 2, 11 : I-I20.

Seguenza, G. I880. Le formazioni terziarie nella provincia di Reggio (Calabria). Memorie Accad. pont. Nuovi Lincei 6:3-443, pls 4-17, 2 maps.

Stoddart, W. W. I86r. On a Microzoa bed in the Carboniferous limestone of Clifton, near Bristol. Ann. Mag. nat. Hist. ser. 3, 8:486-49o.

Swain, F. M. I963. Pleistocene Ostracoda from the Gubik Formation, Arctic coastal plain, Alaska. J. Paleont. 37 (4) : 798-834.

Tizard, T. H., Moseley, H. N., Buchanan, J. Y. \& Murray, J. I885. Narrative of the cruise of 'H.M.S. Challenger' with a general account of the scientific results of the expedition. Rep. scient. Results Voy. Challenger. Narrative 1: I-I I Io. 
Dr Harbans S. Puri Bureau of Geology 903 West Tennessee St TAllahassee FLORIDA 32304 U.S.A.

Dr Neil C. Hulings

Faculty of Science UNIVERSITY OF JORDAN AMMAN JORDAN 


\section{$2 \mathrm{BHL}$ Biodiversity Heritage Library}

Puri, H S and Hulings, N C. 1976. "Designation of lectotypes of some ostracods from the Challenger expedition." Bulletin of the British Museum (Natural History) Zoology 29, 251-315. https://doi.org/10.5962/bhl.part.6924.

View This Item Online: https://www.biodiversitylibrary.org/item/19532

DOI: https://doi.org/10.5962/bhl.part.6924

Permalink: https://www.biodiversitylibrary.org/partpdf/6924

\section{Holding Institution}

Natural History Museum Library, London

\section{Sponsored by}

Natural History Museum Library, London

\section{Copyright \& Reuse}

Copyright Status: In copyright. Digitized with the permission of the rights holder.

Rights Holder: The Trustees of the Natural History Museum, London

License: http://creativecommons.org/licenses/by-nc-sa/4.0/

Rights: http://biodiversitylibrary.org/permissions

This document was created from content at the Biodiversity Heritage Library, the world's largest open access digital library for biodiversity literature and archives. Visit BHL at https://www.biodiversitylibrary.org. 